\title{
STUDIES
}

in

AFRICAN LINGUISTICS

\section{JULY 1978}

Volume 9, Number 2

Published by the Department of Linguistics and the African Studies Center University of California, Los Angeles 
Published by the Department of Linguistics and the African Studies Center

The University of California, Los Angeles

Editorial Board

Baruch Elimelech

Victoria Fromkin

Talmy Givon

Mazisi Kunene

Peter Ladefoged

Carol Lord

Thomas Penchoen

Paul Schachter

Yero Sylla

Benji Wald

William E. Welmers

Joint Editors

Thomas J. Hinnebusch

Russell G. Schuh

Subscription: Individuals:

Institutions :

Overseas air mail:

Single issues:

Supplements :
Associate Editors

John Eulenberg, Michigan State

Robert Hetzron, UCSB

Larry Hyman, USC

Leon C. Jacobson, Maiduguri

William R. Leben, Stanford

Martin Mould, USC

Paul Newman, Leiden

Thomas H. Peterson, CSULA

Carol Myers Scotton, Michigan State

Herbert Stahlke, Georgia State

Erhard Voeltz, Honolulu, Hawaii

\section{Editorial Assistance}

Alice McGaughey

John Singler

Ann West

$\$ 8.00$ per volume

$\$ 12.00$ per volume

$\$ 15.00$ per volume

$\$ 4.00$

$\$ 8.00$ (if ordered separately or as part of earlier volume)

Make checks payable to: African Studies Center

Studies in African Linguistics is published three times a year. Supplements are independently financed and are sent free of charge with current subscriptions. Authors receive 25 free offprints of published articles. Papers submitted to the journal should be sent in triplicate.

For subscriptions and editorial information, please write:

The Editors, Studies in African Linguistics

Department of Linguistics

University of California

Los Angeles, CA 90024

Volume 9, Number 2, July 1978

Copyright 1978

By the Regents of the University of California 
STUDIES IN AFRICAN LINGUISTICS

volume 9, Number 2

July 1978

'LABLF OF' CON'TENTS

\section{$\underline{\text { Articles }}$}

Okon E. Essien, POSSESSIVE PRONOMINALIZA'IION AND THE SO-CALLED

PICTURE NOUNS IN EFIK . . . . . . . . . . . . . . . 121

Robert K. Herbert, ANOTHER LOOK AT META-RULES AND "FAMILY UNIVERSALS" . . . . . . . . . . . . . . . . . . 143

David Dwyer, WHAT SORT OF TONE LANGUAGE IS MENDE? . . . . . . . . . 167

\section{Papers from the 8th Conference on African Linguistics}

Language Planning Working Group

Rachel Angogo, IAANGUAGE AND PULIT'ICS IN SOUI'H AFRICA . . . . . . . 211

Al-Amin M. Mazrui, THE RELIGIOUS FACTOR IN LANGUAGE NATIONALISMTHE CASE OF KISWAHILI IN KENYA . . . . . . . . . . . 223

Tshimpaka Yanga, LANGUAGE PLANNING AND ONOMASTLCS IN ZAIRE • • • 233 

St גdies in African Linguistics

Vclurie 9, Number ź, Iuiy $197 \hat{~}$

\author{
POSSESSIVE PRONOMINALIZATION AND THE SO-CALLEL \\ PICTUPE WOUNS IA EFIK. \\ OKon E. Essien \\ University of Calabar, Calabar, ligeria
}

\begin{abstract}
Mris parer attempts to aralyse possessive We's within the general framework of pronominalization (from a basically Chorskiar viswpoint). To decide how best to grersete such IP's in the Erammar of the Ifik language, the analysis which derives such IIP's from an embedde'd 'hisve' sentential source in a complex sentence is critically examined and on both semantic snd syntactic ercuris, this kirici o $\hat{i}$ analysis is rejected. It is trier sugetests that fossessive N's be directly generated ir. the iase. Firally, the paper relates the so-callea picture rours to possessive pronominalization by adducirg syrtactic, semantic and tonal argumerts to show that such nomirais are in fact possessive rather than reflexive iri riature.
\end{abstract}

\title{
1. Introduction
}

This paperi attempts to analyse possessive INP's within tre general framework of Pronominalization and to relate the so-called ricture rours to such INP's. Our approach to Pronominalization is basically Chomskian. Within this theoretical framework, Pronominalization car roughlly be definea as the process whereby an in in a phrase marier is reflaced iy some pronominal form, provided:

(i) such an IVP bears a coreferential relation with some other IVF in the phrase marker;

\footnotetext{
${ }^{1}$ This paper is taken from Essien [1974a:. Fones are indicated as follows:

- High Tone

- Downstepped Pone

- Low Tone

- Rising Tone

- Falling Tone
} 
(ii) the NP does not violate those known constraints, e.g. Langacker's backward condition, with respect to the application of $T$ in the phrase marker, where $T$ stands for the necessary transformational rule;

(iii) the phrase marker itself is of a certain configuration, e.g. reflexivization applies in a simplex.

\section{Possessive Pronominalization}

By Possessive Pronominalization, we mean the pronominalization process by which the pronominal forms ìmì 'my', fò 'your', ésye 'his/her/its', ǹnyìn 'our', ìbùfò 'your (pl)', ḿm’̀ 'their' are derived in cases where they have coreferent interpretations, as in (1):

(1) a. àmì ńyòm ùdèmé ìmì

b. àfò òyòm ùdèmé fò

c. ènyé óyòm ùdèmé ésìe

d. ìnyìn ìyòm ùdèmé ǹnyìn

e. ìbù fò èyòm ùdèmé mìùfò

f. ḿṁ̀ éyòm ùdèmé ḿm
'I want my share'

'you want your share'

'he/she/it wants his/her/its share'

'we want our share(s)'

'you (pl) want your share(s)'

'they want their share(s)'

It should be noted that except in the singular, where there are minor differences in form, the personal and the possessive pronouns are the same in form.

Strictly speaking, it is only the third person possessive pronouns (ésie and ḿm ) which may be transformationally derived in the manner described in Section 5. The first and second person possessive pronouns, m̀mì, fì, ǹnyìn and m̀bùfò , characteristically occur in the base, or are derived by the Pronoun Conjunction Rule, as we shall see in Section 5.

\section{Analysis of Possessive NP's}

Within the standard transformational-generative theory, an English sentence such as (2a) is derived from a structure underlying (2b), which contains an embedded relative $\mathrm{S}$ :

(2) a. This is my book.

b. This is the book which I have.

We refer to this analysis as the "complex sentence" analysis. In Efik, 
however, there are strong reasons against the "complex sentence" analysis of possessive NP's such as idèmé ésǐe, ìdèmé mmò, etc. as we shall see presently. Since the grammatical function of possessive pronouns such as ésìe, immì, etc. is similar to that of the determiner, our derivation of possessive NP's will have to take this into account. For our purposes, we will call NP's such as ùdèmé éš̌e, úwém Atá 'Ata's life' "possessive NP's". In Efik, the possessor, for example, éše or Ata, follows the thing possessed, such as ùdèmé or úwém in the phrases ùdèmé ésìe and úwém Atá, respectively.

We present facts and arguments against the "complex sentence" analysis of possessive NP's. Consider the following examples:

(3) a. inś êyìp mónótò Ata 'a thief has stolen Ata's car' b. ?ìnó êyìp ḿmotò émì Àtá ényénédé

'a thief has stolen the car which Ata has'

(4) a. Bássèy ímáhá ǹdìtò ésìe

'Bassey doesn't like his children'

b. Bássèy ímáha ǹditò émì ènyé ényénédé 'Bassey doesn't like the children which he has'

(5) a. èkpàt ǹnyìn órò édi émi 'that $\underset{2}{1} \underset{1}{ }$ of ours $\underset{3}{\text { is this' }}$

b. *èkpàt órò émì ǹnyìn inyénédé édí émì 'the bag which we have is this'

First, there is the problem of the grammatical status of $(3 b)$ and $(5 b)$, which are questionable and ungrammatical respectively. The fact that the complex sentence paraphrases of the possessive sentences of $(3 a)-(5 a)$ kind vary in grammaticality is a strong.case against, deriving such possessive sentences from such complex sentences. Second, even in cases where the complex sentences are grammatical, there is a semantic problem, for (4a) and (4b), for example, are not paraphrases as such, as those who favor this kind of analysis would wish. For while (4a) merely states the fact that Bassey does not love or like his children, (4b) carries the implication that he does love other children. Similarly, even if $(3 \mathrm{~b})$ were grammatical, I am not at all sure whether it is semantically equivalent to ( $3 a)$.

Next, consider the following examples, which pose semantic problems of different sorts: 
(6) a. ké mbóp úfò̀ m̀mì

'I am building my house'

b. ké ḿbòp úfòk émì ńnyénédé 'I am building a house which I have'

(7) a. Atá óyòm níd dép ḿmótò ésìe 'Ata wants to buy his car'

b. Atá óyòm ńdídép ḿmótò émì ènyé ényénédé 'Ata wants to buy the car which he has'

(8) a. ḿmò íkwé úbók útòm ḿmò 'they haven't found their occupations'

b. ḿmò íkwé úbók útòm émi ḿm̀̀ ényénédé 'they haven't found the occupations which they have'

Although $(6 \mathrm{~b}),(7 \mathrm{~b})$ and $(8 \mathrm{~b})$ are syntactically well-formed, they are semantically anomalous, for úfj̀k 'house', ḿmótò and úbók útòm 'occupations' are "owned" though they do not in fact exist. ( $8 \mathrm{~b})$ is particularly problematic because of the apparent contradiction there-they have not yet found the occupations and yet they "have" them. However, these are problems for those who favor the complex sentence derivation of possessive NP's.

Syntactically, there are also convincing reasons against the complex sentence analysis. Consider personal names, for example, as in (9):

(9) a. Arìt Inyàng

b. Imé Akpàn

which in fact mean the following respectively: Inyang's Arit and Akpan's Ime. Support for this claim comes from such questions and answers as those in (10).

(10) a. Ùfàn ànie? 'whose friend?' Ans. Inyàng 'Inyang's'

b. éyén ànY̌e? 'whose child?' Ans. Akpàn 'Akpan's'

Note that personal names are similarly patterned, as the examples in (11) indicate.

(11) a. Arìt ànìe? 'whose Arit?' Ans. Inyàng 'Inyang's'

b. Imé ànǐe? 'whose Ime?' Ans. Akpàn 'Akpan's'

Observe that the order of these personal names is the same as for the ordinary possessive NP's: the possessor follows the possessed. If personal names of the kind in (9) could be regarded as possessive NP's of some sort, it would be simply ludicrous to derive them from such strings as (12):
a. *Arit émi lnyàng ényénédé
'Arit which Inyang has'
b. *Imé émì Ákpán ényénédé
'Ime which Akpan has' 
Perhaps the strongest case against the derivation of possessive NP's from complex sentences with an embedded relative $S$ with nyene 'have' can be seen from the following examples. First consider (13):
(13) a. Efffìong ênyéné ḿmótò
'Effiong has a car'
b. Effìong ênyéné ḿmótò ésìe
'Effiong has his own car'

where both ńyéné, which, according to the complex sentence analysis, is supposed to be the source of possession, and a possessive pronoun (esie) occur together. If nyéné is the source of possession, then (13b) should be paraphrasable as (14).

\section{(14) *Êffiong ênyéné mmótò émì ènyé ényéndédé}

'Effiong has a car which he (Effiong) has'

The above example, (14), shows that although nyéné may be a source of possession, it is certainly not the case that all possessive cases are derived from the nyéné source.

Second, consider the following:

(15) a. Bássèy ôkút jwán éyèn fò 'Bassey has seen your son's wifé If the complex sentence analysis is correct, then (15a) should be paraphrased as (15b) and derived from the structure underlying this example:

(15) b. *Bássèy ôkút owán émì éyén ényénédé émì àfò ènyénédé

'Bassey has seen the wife which the son has which you have'

Not only is (15b) ungrammatical but it is also semantically anomalous, since it means both the son and father have the same wife.

Third, the ungrammaticality of (16a) is significant:
a. *èkà Imé ${ }_{i}$ óyòm ènyé ${ }_{i}$
'Ime's mother wants him'

where ènyé refers to Imé . The ungrammaticality ${ }^{2}$ of the above sentence is easily accounted for by the fact that as a simplex the structure underlying it does not qualify as a proper analysis for simple pronominalization,

\footnotetext{
${ }^{2}$ In some dialects (16a) seems to be grammatical. In such dialects, then, simple pronominalization is not limited to the complex. Even so, (16b) is clearly preferable to (16a) is such dialects.
} 
which in Efik occurs only in complex and conjoined structures. If the structure underlying $(16 \mathrm{a})$ is a simple structure, then it cannot also be a complex structure at the same time. In other words, èkà Imé 'Ime's mother' is not in fact derived frum a sentential source. Incidentally, the way to save (16a) is not to pronominalize the object of the sentence, which is Ime, in the deep structure, as the grammaticality of (16b) shows. (16) b. èkà Imé óyòm Imé 'Ime's mother wants Ime'

Finally, from a general linguistic point of view, Lyons [1968:391-95] has argued that an analysis which derives possessive phrases such as 'John's book' from an underlying source in which the possessor noun like 'John's' is the deep subject and the verb 'have' is a deep structure verb is incorrect:

\footnotetext{
"In most of the transformational accounts of English syntax so far published, it has been assumed that phrases like John's book are to be derived from an underlying structure in which the 'possessive' noun is the subject of the verb 'have': in other words, it is assumed that have is a deep structure verb (like read, etc.), which differs, however, from the majority of transitive verbs in that (in possessive sentences) it cannot undergo the passive transformation (*A book is had by John). There are many reasons for believing that this account of the relationship between 'have' sentences and possessive phrases is incorrect" (p. 391).
}

In our analysis 'have', or nyene in Efik, is in fact not a deep structure verb but is transformationally introduced.

Interestingly, Lyons has shown, in support of his position, that expressions such as 'John's' above is a kind of adjective. But an adjective is a noun modifier. Although in Efik expressions such as Ime in the phrase èkà Imé 'Ime's mother' are not adjectival in function and syntax, they certainly act like a noun modifier, as we will show presently.

Enough has been given to show that there are very grave problems if one wishes to derive possessive sentences from complex sentences containing embedded relative clauses with nyene. The question then is, how best can they be derived? We think that possessive NP's should be derived in the base with the possessor NP as a constituent of the determiner system by the following expansion rules of the base: 


\begin{tabular}{|c|c|c|c|}
\hline (i) & NP & $\rightarrow$ & $\mathrm{N}$ DET \\
\hline (ii) & DEr & $\rightarrow$ & NOM ART \\
\hline iii) & NOM & $\rightarrow$ & NP \\
\hline
\end{tabular}

The possessor NP wili be dominated by the NOM of the DET. Given a possessive INP like èbé éše 'her husband', the structure would look like the following:

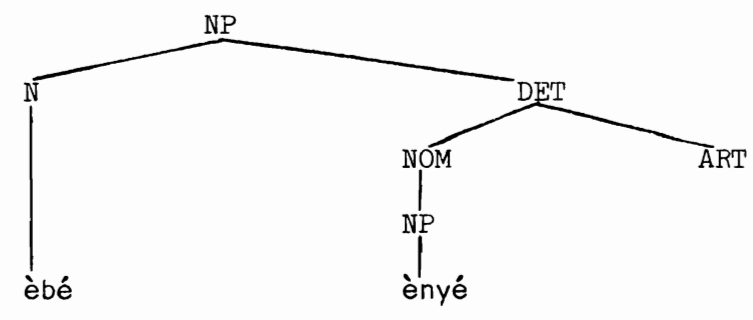

The analysis of possessive NP's as part of the determiner is justified on both syntactic and semantic grounds. There are two kinds of noun modifiers in Efik, namely pre-nominal modifiers like quantifiers and Wh-question morphemes, and post-nominal modifiers like demonstratives, the definite article and numerals, which together constitute the determiner system. Observe, for example, that (17a) parallels (17b): (17) a.

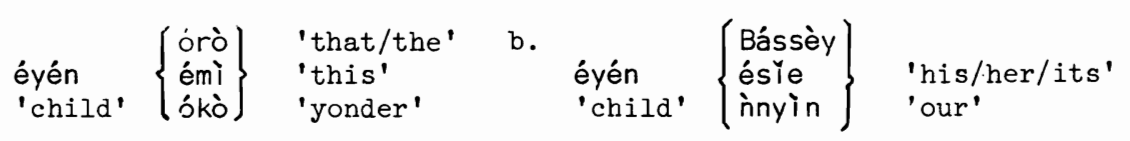

It is not only in Efik that possessor NP's behave like nominal modifiers.

In English, as shown above, Lyons has shown that NP's like 'John's' are adjectival in function in such phrases as 'John's book'. On the other hand, Postal [1966] has argued that elements such as 'my', 'our', 'him' in 'myself', 'ourselves', and 'himself' respectively "are of course articles, definite articles, in fact genitive type definite articles".

Semantically, the possessor NP, like the demonstrative or article, appears to definitize the NP in which it occurs. Thus, in (18), for example, where only definite NP's occur in the subject position, a possessive NP occurs as a subject.

(18) a. éyén Okón ésímà nidîtàn idém éti éti

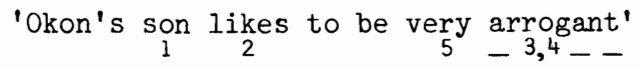


(18) b. éyén órò ésímà nítàn ídém ét 1 et i

'that child likes to be very arrogant'

c. Atá ésimà ńdîtàn ídém étl étl

'Ata likes to be very arrogant'

d. *éyèn ésimà niditàn idém étl ètl

'a child likes to be very arrogant'

\section{Compound Nominals}

As we have seen above, a possessive NP is a complex NP, by which I mean an NP dominating another NP (or other NP's). There are some nominals which look like possessive NP's and we wish to examine whether they do in fact qualify as possessive cases. Consider the following examples:
a. étó ńwèd
b. òkpókóró údǐa
c. úfòk ibjok

'a stick for writing'

'a table for eating'

'a house for medicine'

Syntactically, the NP's in (19) look like possessive NP's: there is a preceding and a following nominal in each case, just as in the possessive case. However, as even the English glosses show, there is no basis for a possessive interpretation of these NP's, from a semantic point of view. These NP's characteristically involve instrumentality or purpose: thus étó 'jweò' is 'a stick for writing' or 'a stick for the purpose of vriting'. A possessive g̃loss like 'a book's stick' for étó ńwèd is clearly unacceptatle. Similarly, an instrumental gioss for a possessive tF like éyén Bássèy 'Bassey's child' would be clearly unacceptable. Thus 'a child usea for Bassey' is clearly not a gloss for éyén Bássèy.

There are also syntactic differences between the NP's in (19) and possessive IP's. While the NP's in (19) may allow the plural morpheme rme, some possessive NP's do not, as (20) and (21) respectively show.
(20) a. ìmè étó jówèd
'pens'
b. ìmè òkpókóró údía
'dining tables'
c. ìmè úfj̀k íbj̀
'hospitals' 
(21) a. *immè j̀ivèd Okón

b. ìmè èkpàt éyèn òrò

c. ìmmè bîa ǹnyìn
'Okon's books'

'the boy's bags'

'our yams'

However, ìmè èté ńdito órò 'the fathers of those children' and àmè èbé íbàn órò 'those women's husbands' are grammatical, where both NP's are [+Human]. It should be noted that in (21), although the possessors are human, the things possessed are inanimate.

Secondly, while a possessive NP like èkpàt Bássèy émì 'this bag belongs to Bassey' or 'the bag belonging to this Bassey' is structurally ambiguous, as the phrase markers in (22) show, an NP such as étó ńwèd émi 'this pen' is not.

(22) a.

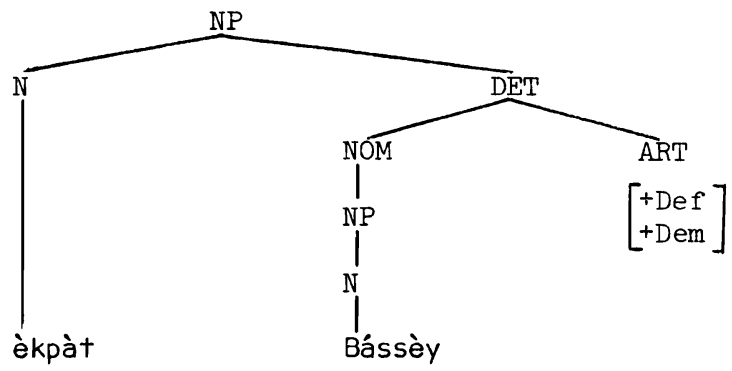

b.

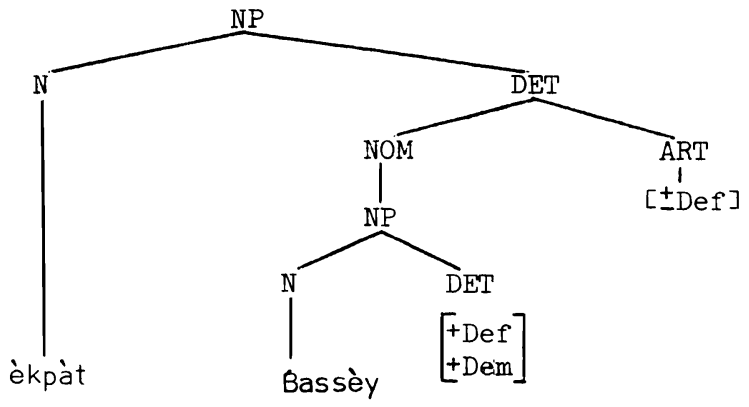

(22a) underlies the interpretation 'this bag of Bassey', while (22b) underlies 'the/a bag of this Bassey'.

Therefore, such NP's as étó j́wèd, úfj̀k íbj̀k, òkpókóró údìa are not not possessive, though they look like such NP's in form. Rather one may regard them as such English compounds as 'night show', 'play group', 'baby sitter', etc. We suggest therefore that they be analysed as compounds. 
We shall not attempt the analysis of compounds here. Langacker [1972:77] suggests that for such compounds as 'armchair', 'rattlesnake', etc. this rule will work:

"The meaning $\mathrm{N}_{1}$ with $\mathrm{N}_{2}$ can be expressed by a compound of the form $\mathrm{N}_{2} \mathrm{~N}_{1} \cdot "$

In Efik, however, the meaning $\mathrm{N}_{1}$ for $\mathrm{N}_{2}$ can be expressed by a compound of the form $\mathrm{N}_{1} \mathbb{N}_{2}$. For example, j̀wèd íkwò 'a book for songs' and íkpó ḿbrê 'a thing for play'.

Finally, on the differences between possessive NP's and compounds, observe that the former are a "conjunction" of NP's, if I may be permitted to use this expression in a rather special sense, whereas the latter are a "conjunction" of II's. This follows from our observation that whereas NP's like èkpàt Bássèy émì are structurally ambiguous, NP's like úfj̀k ńwèd émì 'this house for books', i.e. 'school' are not.

\section{Formulation of Possessive Pronominalization}

We shall now turn to the central concern of the paper, namely, the formulation of Possessive Pronominalization, which we shall sometimes refer to as the "possessive rule". Consider, for example, the simple sentence in (23):

(23) Imé éyényàm mmótò ésie 'Ime will sell his car'

(23) is structured as (24a), omitting the details:

(24) a.

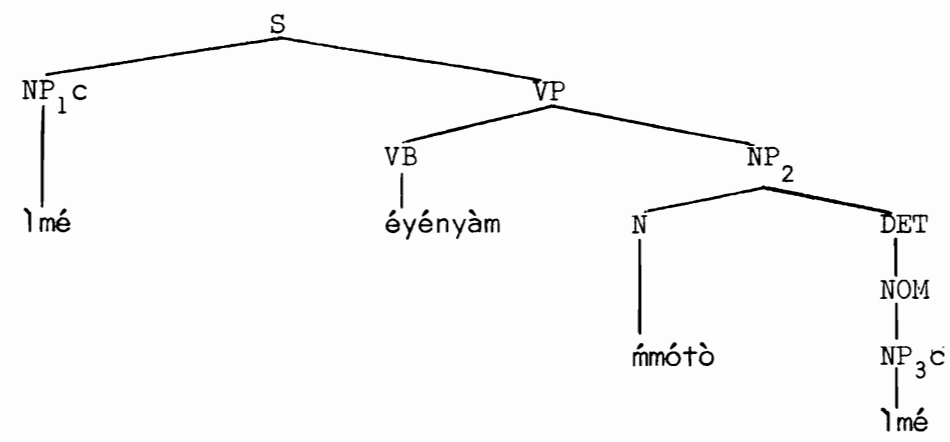

The possessive rule will apply to a configuration like (24a) provided:

(i) $\mathrm{NP}_{1}$ and $\mathrm{NP}_{3}$ are coreferential;

(ii) $\mathrm{NP}_{3}$ is immediately preceded by an $\mathrm{N}$; 
(iii) the $\mathrm{N}$ that immediately precedes $\mathrm{NP}_{3}$ must be the head noun of the DET that dominates $\mathrm{NP}_{3}$.

Let us suppose for the moment that the above conditions are not only necessary but also sufficient for the application of the possessive rule. But do these conditions guarantee that in a phrase marker like (24a) above, it is possessive pronominalization and not reflexivization that applies, since (24a) is after all a simplex? (Reflexivization is limited to the simplex in Efik).

We will answer this question by comparing a proper analysis for reflexivization, such as the phrase marker in (24b), with (24a).

(24) b.

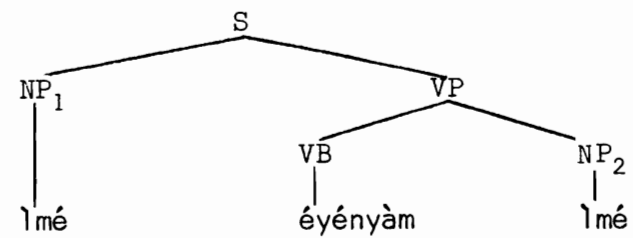

Reflexivization will apply to $(24 \mathrm{~b})$ if $\mathrm{NP}_{1}$ and $\mathrm{NP}_{2}$, which are subject and object respectively in a simplex, are coreferential. Doubtless, (24a) and (24b) are similar. But they also differ, in fact in a non-trivial way. Observe that in $(24 \mathrm{~b}), \mathrm{NP}_{2}$, which is identical with $\mathrm{NP}_{1}$, is the object of the simplex (being immediately dominated by the VP), whereas in (24a), $\mathrm{NP}_{3}$, which is identical with $\mathrm{NP}_{1}$, is not the object of the simplex as such. It is only part of the object $\mathrm{NP}, \mathrm{NP}_{2}$ (which is immediately dominated by the VP). Clearly (24a) is not a proper analysis for reflexiviation and the conditions for the application of the possessive rule seem to recognize this. So given the phrase marker such as (24a) and the conditions for the application of possessive pronominalization as spelled out above, reflexivization on such a phrase marker is ruled out. Observe that the conditions for possessive pronominalization make no mention of the simplex condition and although coreference is one of the conditions, it is not required that this hold between the subject and object in a phrase marker such as (24a). However, possessive pronominalization is blocked if the NP for this rule is part of the subject, as (25) shows. 


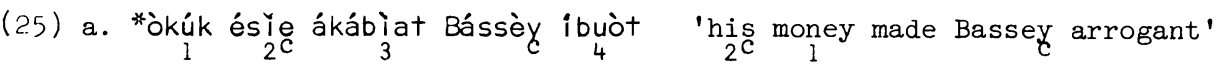

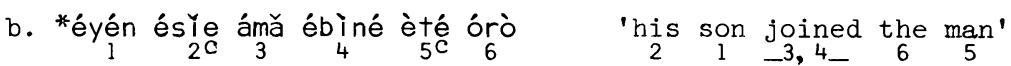

Apparently the constraint on backward pronominalization is violated here. However, it does seem as if the constraint does not affect (26) below.

(26) a. òkúk ésīe ké Bássècy ákábìat

'it is his money that Bassey wasted'

b. éyén ésǐe ké ètęc órò ékébìné

'it is his son that the man joined'

The constraint is not in fact violated since $(26 a, b)$ derive from $(27 a, b)$ :

(27) a. Bássèy ákábìat òkúk ésie ce

'Bassey wasted his money'

b. ètéc órò ékébinè éyén ésìe ce

'the man joined his son'

where the pronoun follows the antecedent, in obedience to the constraint. Even if (27) are not exact paraphrases of (26), there is no doubt that they are derived from the latter by a transformation that moves the object out of its normal position (Efik is a SVO language) to the position normally occupied by the deep subject, for topicalization.

In Efik it seems, therefore, that the constraint that does not permit a pronoun to precede the nominal to which it refers in a simplex is operative at the time the possessive rule is ready to apply. There is evidence, too, that this is also true of reflexivization, since (28a) is grammatical and yet the reflexive pronoun clearly precedes the NP Bassey to which it refers. (28) a. idém ésǐe ké Bássèy ótùk

'Bassey has cheated himself'

As in (26), the reflexive pronoun idém ésìe must have been moved to the front from its object position (at which time it obeyed the constraint), by the topicalization transformation, as it seems clear from (28b), from which (28a) is derived.

(28) b. Bássèy ótùk ídém ésìe

'Bassey has cheated himself'

If the constraint on examples such as (26), where the following NP in each case is [-Pro], is operative at the time the possessive pronominalization is ready to apply, it is not operative at all if the following NP is itself a pronoun as (29) are perfectly grammatical. 
(29) a. étè mì óyòm mi

b. èbé fò ámá $f \mathfrak{l}$

c. éyén ésǐe cókót ènyéc 'my father wants me'

'your husband loves you'

'his son has called him'

Let us return to the application of the possessive transformation, having seen the sort of configuration on which it operates and the conditions on which it operates. Given the phrase marker (24a) and the fulfillment of the conditions for possessive pronominalization, the rule will apply marking the feature [+Pro] and [+Pos] (Possessive) on the NP which is dominated by DET. If this NP is already [+Pro], the rule will simply mark [+Pos]. In the case of (24a), the NP will later be realized as éšle. In this way, (23) will be generated.

Next, let us take an example which involves both possessive pronominalization and reflexivization. Let us consider (30).

(30) Atá êkpép idém ésìe ìwed̀ yè òkúk ésĩe

'Ata has put himself through school with his money'

Underlying (30) is (3la).

(31) a.

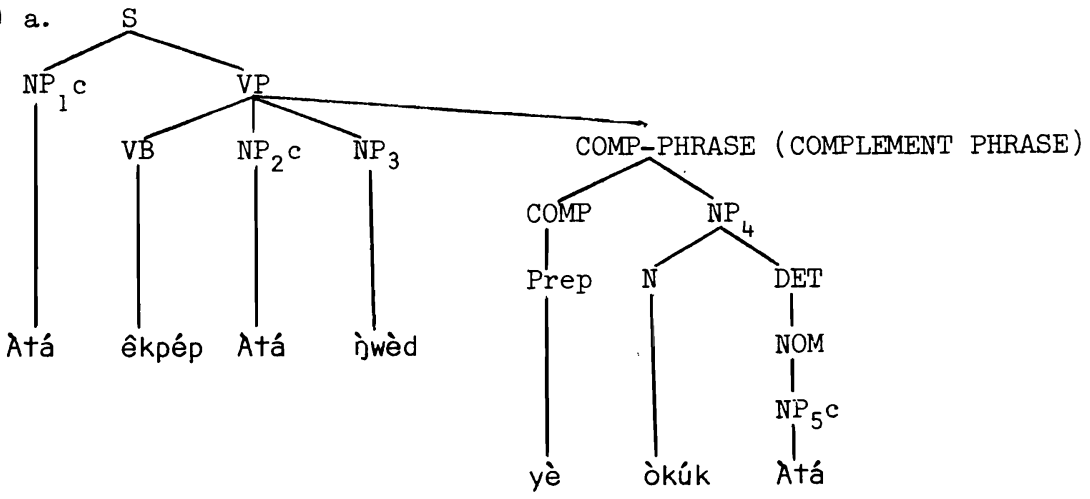

(3la) is a proper analysis for both reflexivization and possessive pronominalization. The question is, which of these two rules precedes the other? We suggest the rules be applied cyclically and that possessive pronominalization precede reflexivization, since the latter will not have to look back to embedded sentences in a complex structure. The application of possessive pronominalization generates (3lb).

(31) b. Atá êkpép Atá ìwèd yè òkúk ésìe

'Ata has put Ata through school with his money' 
When reflexivization applies, $(30)$ is generated.

So far we have been looking at possessive pronominalization in a simplex. Now, consider (32), which is a complex.

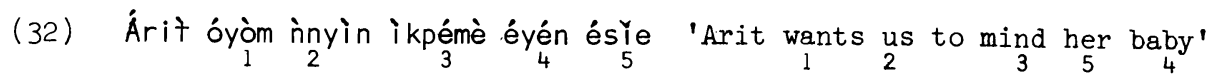
Underlying (32) is (33), omitting details:

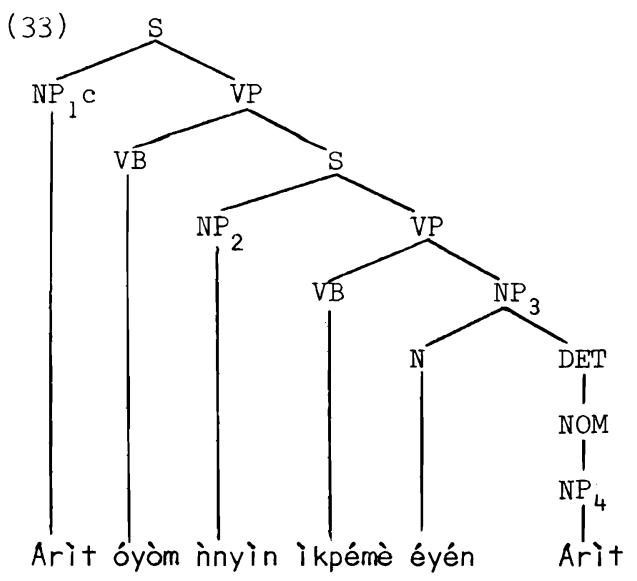

(33) fulfills all the conditions for the application of the possessive rule:

(i) there are two coreferent $\mathrm{NP}^{\prime} \mathrm{s}\left(\mathrm{NP}_{1}\right.$ and $\left.\mathrm{NP}_{4}\right)$;

(ii) one of the coreferent $\mathrm{NP}^{\prime} \mathrm{s}, \mathrm{NP}_{4}$, is immediately preceded by an $\mathrm{N}$ and dominated by a DET;

(iii) the $\mathrm{N}$ that immediately precedes $\mathrm{NP}_{4}$ is a left sister of the DET that dominates the same NP.

(33), therefore, is a proper analysis for possessive pronominalization and when the rule applies, (32) is generated. So possessive pronominalization applies in both simplexes and complexes, provided, of course, the necessary conditions are met.

Backward possessive pronominalization is not permissible even in environments where backward simple pronominalization is allowed. Thus (34). is ungrammatical.

(34) *èdíekè éyén éšl̨ édídé, ńyéš̌an Bássèy i if his son comes, I will tell Bassey' In fact, it seems to be the case that backward possessive pronominalization 
is not allowed whether in a simplex or complex. Recall that ever in (26), at the time the rule applied, it, applied in a forward direction. It was a later rule, Topicalization, which moved the objects, of which the possessive pronouns happen to have been a part, forward. It is orly in (29c), where the following coreferent NP is itself a pronciun, that prosessive pronominalization is apparently seen to have taken place in 2 backward direction.

In Section 2, we said that the first and second person possessive pronouns ìmi/ǹnyìn 'my/our' and fò/mbìtò 'your/your ( $p 1)$ ' characteristically occur in the base, or are derived by the Pronoun Conjunction Rule. Examples such as (35) are straightforward cases: the possessive pronouns occur in the base as àmi ' $I$ ' and àfò 'you', as the underlying structures in (36) show.

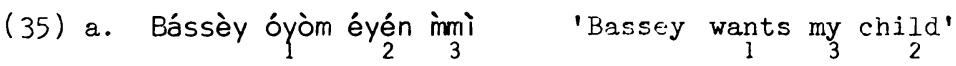

b. ènyé êwèt ényín fò ${ }_{4} \quad{ }_{1}$ he has written your name'

(36) a.

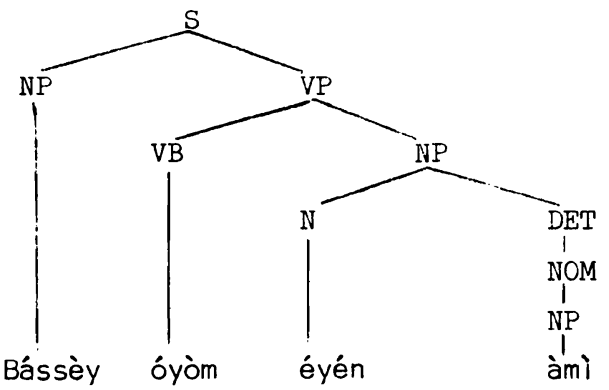

b.

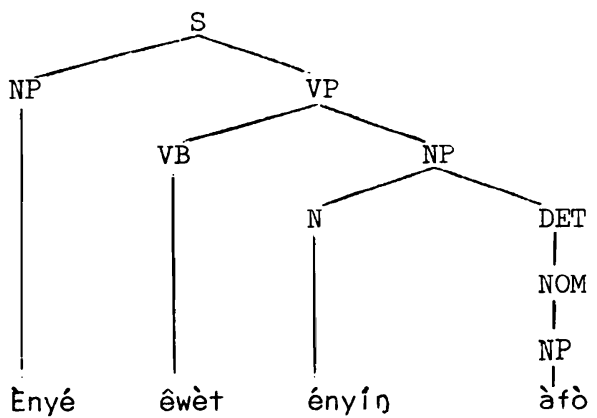




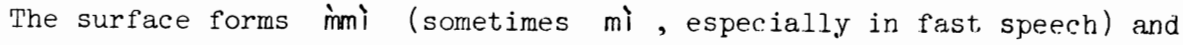
fò are derived by a morphophonemic rule. Observe that the morphophonemic rule is not necessary in the case of the plural possessives. Thus óbio ǹnyìn 'our country', óbǐo mibùfò 'your country', and óbǐo ḿmò 'their country' are derived from $(37 a),(37 b)$, and $(37 c)$ respectively.
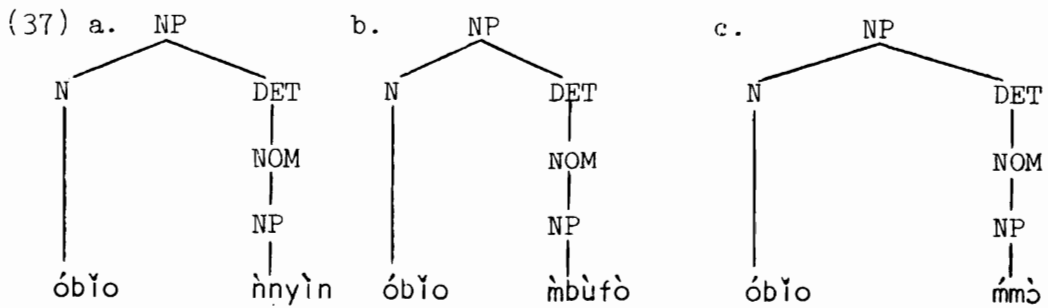

So the rule is required required to apply only in the case of [+Sing] pronouns in such structures as (36) and (37).

In the following examples, however, it seems that ǹnyìn and mbùfò are derived by the Pronoun Conjunction Rule:

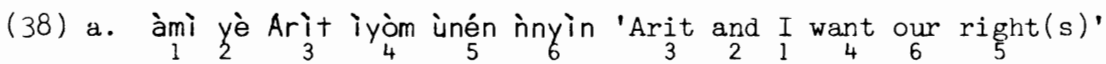
b. àfò yè Arìt èyòm ùnén m̀bùfò 'you and Arit want your right(s)'

The Pronoun Conjunction Rule derives, among other things

(a) The First Person Plural from a conjunction of the First Person (singular and plural) with either of the other persons or in fact both of these persons at the same time;

(b) The Second Person Plural from a conjunction of the Second Person (singular or plural) with the Third Person.

Thus we have the following:

(39) a. àmìnnyìn yè àfò/minuùfò 'I/we and you/you (pl)'

$$
\begin{aligned}
& =\text { innyìn } \\
& \text { 'we' } \\
& =\text { innyìn } \\
& \text { 'we' } \\
& =\text { ǹnyìn } \\
& \text { 'we' }
\end{aligned}
$$

b. àmîñnyìn yè Arìt 'I/we and Arit'
d. àmì/ǹnyìn yè àfò/ṁbùfò yè ènyé/Arìt/ḿmò = ìnyìn 'I/we and you/you (pl) and he/Arit/they' 'we'

e. àfò/'mbùfò yè ènyé/Árìt/mmò = ìbùfò 'you/you (pl) and he/Arit/they' 'you (pl)' 
The details of the Pronoun Conjunction Rule are discussed in Essien [1974a:158-60]. The point to note here is that certain conjunctions involving pronouns (and other non-pronominal NP's) can be reduced to single pronouns. The reduction is optional in some cases and obligatory in others.

Let us return to the examples in (38) and let us consider (38a) in particular. This sentence is derived from (40), omitting details. (40)

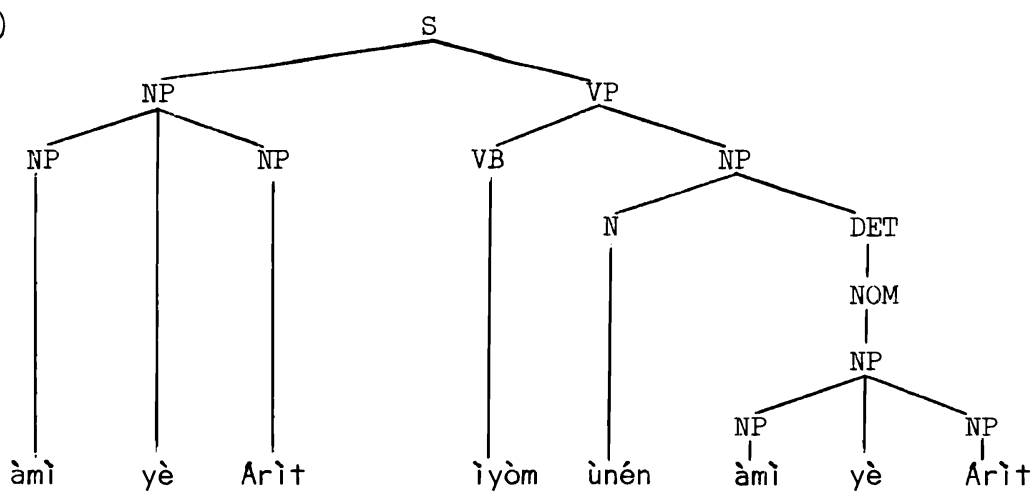

The Pronoun Conjunction Rule will apply to (40) obligatorily deriving ǹnyìn from àmì yè Arìt, which forms part of the object of the $S$. In this way, (38a) is derived. àmi yè Arit as the subject of the sentence can be optionally collapsed to derive innin, thus deriving (41):

(41) ìnyìn ìyòm ùnén ǹnyìn 'we want our right(s)'

6. Possessive Pronominalization and the So-Called Pict,ure Nouns

In English, the sentences such as (42) are considered as reflexive sentences.

(42) a. John saw a picture of himself

b. Mary told a story about herself

Some attempts have been made to analyse 'himself' and 'herself' in the above sentences within the general framework of reflexivization. Thus Jackendoff [1968:14f, 1975:135] suggests that the $\overline{\mathbb{N}}$ analysis of Chomsky [1970] would offer a solution to the derivation of the reflexives connected with nominals like 'picture' and 'story', which have come to be known as "picture nouns". 
In Efik, however, we want to say that the forms connected with the so-called picture nouns are not in fact reflexive pronouns derived as a result of reflexivization but lexical items generated in the base in possessive positions. There are a number of reasons for our analysis. First, although there are sentences like (43), there are also sentences like (44).

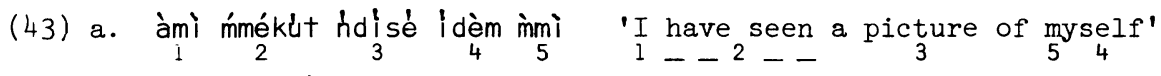

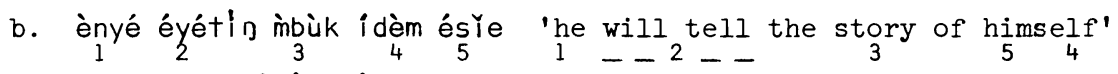
(44) a. àmi ḿmékút 'ndísé İ dèm fò 'I have seen a picture of yourself' b. ènyé éyétln mbùk idèm mì 'he will tell the story of myself' where ídém fò and àmì are not coreferential in (44a) and ídém m̀ni and ènyé are not coreferential in (44b). Surely the sentences in (44) do not qualify as reflexive sentences in our definition (cf. p. 13l, Section 5) and ídèm fò and idèm mmi in these examples cannot therefore be regarded as reflexive pronouns. If so, we ought to look at similar forms in (43) with suspicion, even though they may happen to be coreferential with the subjects of the sentences. For if the forms in (43) were truly reflexive pronouns, then (44) ought to be ungrammatical, where these forms and the subjects of the sentences are not coreferential.

Secondly, whereas the formatives ìmì, ésìe, etc. can be optionally deleted in a reflexive sentence without a change in meaning (cf. Essien $[1974 \mathrm{~b}])$, as (45) show, the possessive forms in (43) cannot be deleted, as the ungrammaticality of (46) show.

(45) a. ènyé ánàm idém éš̀e

b. ènyé ánàm idém

(46) a. *àmì ḿmékút hidisé İdèm

b. *ènyé éyétín mibùk idèm 'he is harming himself'
1 - $-2---1$
'he is harming himself'

'I have seen a picture of myself'

'he will tell the story of himself'

Thirdly, on the other hand, the deletion of idém in (45a), for example, which is a reflexive sentence results in one interpretation, while the deletion of idem in (43) and (44) results in a different interpretation of the sentences, as (47), (48) and (49) which correspond to $(45 a),(43)$ and $(44)$ respectively show. 
(47) ènyé ánàm éš̃e

'he is doing his'

(48) a. àmi ḿmékùt nidisé m̀mì

'I have seen my picture'

b. ènyé éyétín m̀bùk ésie 'he will tell his story'

(49) a. àmì ḿmékút ńdisé fò 'I have seen your picture'

b. ènyé éyétlo m̀bùk m̀mì 'he will tell my story'

Notice in particular that the effects of the deletion of idem in

(43) and (44) are the same. Semantically, (43) and (44) are different

from (48) and (49), respectively. For example, in (43a), nidisé idèm

ìmì means 'a picture of myself' or ('of my person'), whereas ńdisé ìmì

in (48a) means 'the picture that I own' (not necessarily of myself or

my person). In addition, whereas ńdisé in (43a) is indefinite,

ńdisé in (48a) is definite. Similarly in (44a), ńdisé idèm fò is

interpreted as 'a picture of yourself' (or 'your person'), whereas in

(49a) ńdisé fò means 'the picture belonging to you' (not necessarily

of yourself or your person). Again ndisé in (44a) is indefinite

while nidisé in (49a) is definite.

Fourthly, as a lexical item of the nominal class, idèm in (43) can

be preceded or followed by a nominal modifier, like any nominal in the language, but ídém as part of a reflexive pronoun does not allow any modifiers, as (50) and (51), respectively, show.

(50) a. àmì ḿmékút ńdisé èdịyè idèm m̀mì 'I have seen a picture of my pretty

b. ènyé éyétín m̀bùk idèm ésǐe órò 'he will tell a story of that self

(51) a. *àmi ḿményáná èdiyě idém m̀mi ${ }^{3}$ 'I have helped my pretty self'

b. *Bássèy ówòt idém ésĩe órò 'Bassey has killed that self of his'

In addition, the reflexive-like forms in (43) are freely used with non-picture nouns, as these examples show.

(52) a. ńyòm òkúk id dèm ìmmì

'I want my $\underset{3}{\operatorname{mansonal}} \underset{2}{-}$

3àmi ḿmékút èdiyě idèm m̀mì ké úkút ísó 'I have seen my pretty body in the mirror' is grammatical. But here idèm means 'body', not 'self'. 
(52) b. Atá idigé éyén idèm fò

'Ata is not your begotten child (i.e. is adopted)'

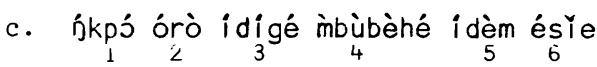

'that thing is not his personal affair'

where reflexive interpretations are highly improbable. Clearly ídèm ìmì , ídèm fó and ídèm ésie in (52) are possessive in form and meaning. This interpretation of the reflexive-like forms in (52) is clearly applicable to the same forms in (43) and explains the grammaticality of (44), where these elements are not coreferential with the subjects of the sentences.

Finally, the tone pattern on idèm indicates that idèm is in fact a possessor nominal, much like ébòt 'goat's' in the phrase isim ébòt 'a goat's tail' in (53c) below. It should be pointed out that in Efik, tones are used not only to distinguish lexical items but also to indicate certain syntactic relationships or functions. Now let us consider the following examples:
a. ènyó nótò
'a tree's top'
b. èbé éyèn
'a daughter's husband'
c. isim ébòt
'a goat's tail'

where the tones on étò, éyèn and ébòt are high-low. "Inherent" tones on these lexical items are high-high, as (54) show.
(54) a. étó
b. éyén
c. ébót

'a tree'

'a daughter'

'a goat'

That is the tones on étó, éyén and ébót are ordinarily high unless they are affected by some gramatical process or processes.

Now consider the tones on idèm in (43) (and also (44)). They are exactly like the tones on étò, éyèn and ébòt in (53), namely highlow (unless the high tone is slightly lowered by a preceding downstepped high as in (43a)). "Inherent" tones on the lexical item idèm 'body' or 'self' are high-high, as these examples show. 
(55) a. idém mimi iśruké 'my body/self is not well (i.e. I'm not well)'

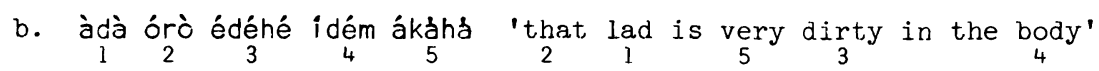

Like the "inherent" tones on étó, ébót and éyén, the "inherent" tones on idém can be affected by some grammatical processes. Note that the tone pattern on idèm in the reflexive sentences such as those in (30) and (45) indicates a different grammatical relationship from that indicated by the tone pattern on idém as a possessor nominal in (43) and (44).

The syntactic, semantic and the tonal arguments given above strongly support our analysis of the sentences in (43) as possessive rather than reflexive sentences. The difference between (43) and ordinary possessive sentences such as those in ( 1 ) in Section 1 is that the possessive sentences in (43) have two possessor NP's namely idém and a personal pronoun whereas those in ( 1 ) have only one possessor NP, namely the personal pronoun. Accordingly, (43) are derived from (56), omitting the details.

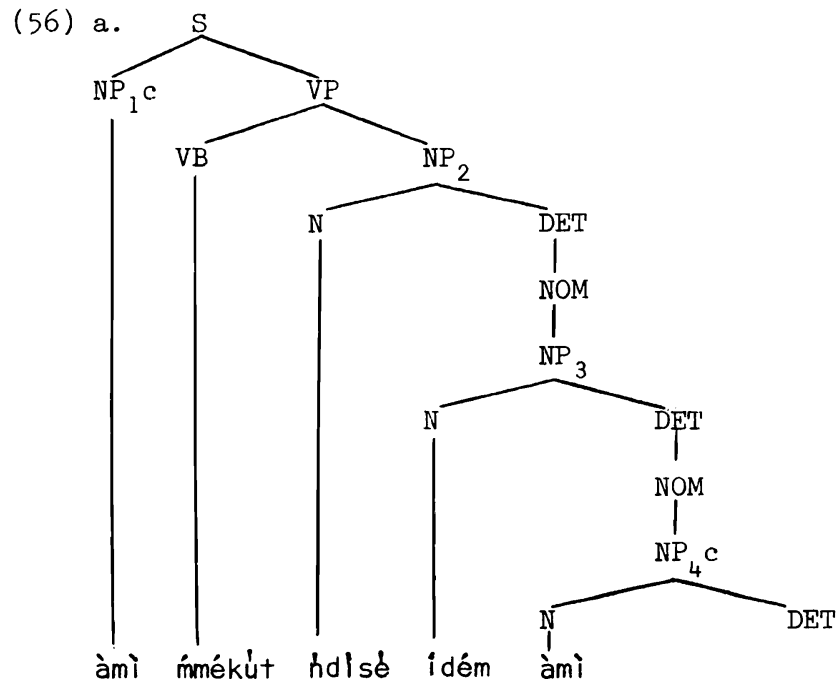


(56) $b$

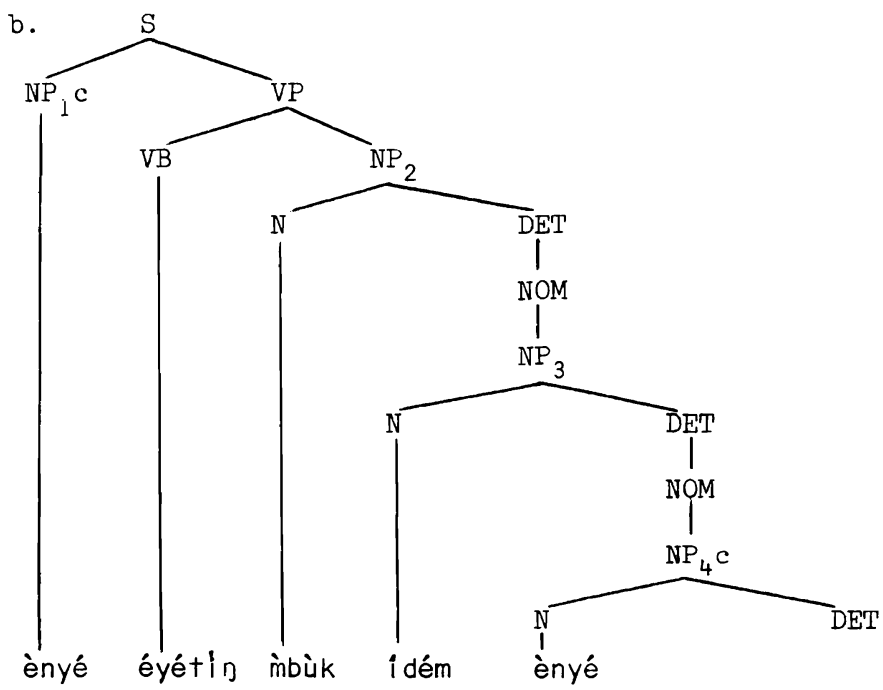

As (56a) and (56b) are proper analyses for possessive pronominalization, the rule will apply in the two structures deriving (43a) and (43b) respectively.

\section{REFERENCES}

Chomsky, N. 1970. "Remarks on nominalization." In R.A. Jacobs and P.S. Rosenbaum (eds.), Readings in English Transformational Grammar, pp. 189-221. Waltham, Mass.: Ginn and Company.

Essien, O.E. 1974a. "Pronominalization in Efik." Doctoral dissertation, Edinburgh University.

Essien, O.E. 1974b. "The reflexive in Efik." Journal of African Languages $11(2): 7-20$.

Jackendoff, R. 1968. "An interpretative theory of pronouns and reflexives." Mimeo, Indiana University Linguistic Club.

Jackendoff, R. 1972. Semantic Interpretation in Generative Grammar. Cambridge, Mass: M.I.T. Press.

Langacker, R.M. 1972. Fundamentals of Linguistic Analysis. New York: Harcourt Brace Jovanovich.

Lyons, J. 1968. Introduction to Theoretical Linguistics. Cambridge: Cambridge University Press.

Postal, P.M. 1966. "On so-called pronouns in English." In R.D. Jacobs and P.S. Rosenbaum (eds.), Readings in English Transformational Grammar, pp. 56-82. Waltham, Mass: Ginn and Company. 


\title{
ANOTHER LOOK AT META-RULES AND "FAMILY UNIVERSALS"*
}

Robert K. Herbert

Michigen State Unirersity

\begin{abstract}
This paper addresses the general question of languagespecific meta-rules within the setting of a reconsideration of recent proposals by Katamba [1977] concerning the articulatory mode of Luganda. In particular, it examines Katamba's claim that language-specific considerations can override universal marking values in phonology, producing segments which are counterpredicted by markedness theory. Developments such as the creation of geminate consonants lead Katamba to accept Lass' [1972] proposal that the universal basis of markedness theory be rejected and replaced by "family universals". This paper provides a reanalysis of certain data cited by Katamba in support of his analysis and also raises some general theoretical questions conserning the notion of phonological meta-rule. In Sections 4 and 5, Lass' proposal is examined in detail via the example of click sounds in Southern Bantu languages. It is demonstrated that, contrary to Lass' assertion that clicks are neither marked nor unmarked in click languages, the evidence of diachronic and synchronic language behavior clearly supports their marked status.
\end{abstract}

\section{Introduction}

In a recent article appearing in this journal, Katamba [1977] argues that the operation of synchronic and diachronic phonological processes in certain languages may be governed by meta-rules, i.e. general principles which determine the "phonetic mode" of the language. Katamba considers in detail some data from Luganda, a Bantu language of Eastern Africa, which he claims point to the fact that Luganda phonology is governed

\footnotetext{
*Although they have not had access to the present paper, I would like to thank Gillian Brown. Wolfgang Dressler, Roger Lass, and Arnold Zwicky for stimulating discussions on the nature of markedness and language universals, which discussions helped to shape the latter sections of this paper. Also, I am grateful to Martin Mould for critical comments and suggestions on the contents of Section 2. Naturally, all conceptual flaws and analytical errors remain my own responsibility.
} 
by two general tendencies: Vowel Lowering and Consonant istrenetheninf, In certain instances, e.g. the creation of geminate consonantes under certain well-defined conditions, scements which are counter-predicted by markedness theory are created. Such developments are cited in support, of Lass' [1972] claim that markedness theory is outlined by Chomsky and Halle [1968] is largely devoid of content as a theory of universal predictions. In place of universal markink values, Lass argues in favor of so-called "family universals", i.e. language- or lamily-speciric proposals for marked and unmarked values in phonology. In thi: pruper, Lass' proposal as well as Katamba's more specific analysis of lurrarda. are considered in detail. It will be argued that Liss' rundamential objections to the theory of universal phonetics are not well-founded and that the notion of meta-rule, at least insofar as it effects the "phonetic mode" of Luyanda, is without content.

\section{Vowel Lowering}

The first of the general principles governing Luganda phonology proposed by Katamba is Vowel Lowering. This meta-rule is demonstrated in two examples, one synchronic and one diachronic. The synchronic alternations involve the vowel of the prepref'ix of noun class markers. A partial list of the noun class prefixes and their respective preprefixes follows:

$$
\begin{array}{ll}
\text { 1. o-mu } & \text { 2. a-ba } \\
\text { 3. o-mu } & \text { 4. e-mi } \\
\text { 5. e-C } & 6 \cdot \text { a-ma } \\
\text { 7. e-ki } & 8 \cdot \text { e-bi } \\
\text { 9. e-N } & \text { 10. e-N } \\
11 . \text { o-lu } & \\
\text { 12. a-ka } & \text { 13. o-tu }
\end{array}
$$

The occurrence of the preprefix in a particular environment is determined by the syntax and does not concern the present argument. Historically, the preprefix was a copy of the pronoun or demonstrative of the class; this pattern still occurs in some closely related languages. ' Synchronically,

\footnotetext{
${ }^{1}$ For example, Lumasaaba has the following set of prefixes and preprefixes:
} 
however, the form of the initial vowel is most easily described in terms of a rule such as:

$$
\phi \rightarrow\left[\begin{array}{l}
\mathrm{V} \\
-\mathrm{high} \\
\text { alow } \\
\alpha \text { back }
\end{array}\right] / \text { \#_ }+\mathrm{C}\left[\begin{array}{c}
\mathrm{V} \\
\alpha \text { low } \\
\alpha \text { back }
\end{array}\right]+
$$

i.e. the initial vowel agrees with the prefix vowel in backness and lowness, but it will be [-high] if the prefix vowel is [+high].2 The important generalization is that only three vowels function as prefix vowels, /i u a/, and three vowels are preprefixal vowels, /e $\circ \mathrm{a} /$. Thus, all of the five synchronic vowels of Luganda are represented as initial or prefixal elements.

Katamba points out that the neutralization of non-low vowels in initial position in favor of $/ e \mathrm{o}$ is counterpredicted by the principle of maximum differentiation. That is, if the five-way opposition $/ \mathrm{i}$ e u $\circ \mathrm{a} / \mathrm{is}$ to be neutralized in favor of a three-member set, we expect the maximally distinct / $\mathrm{i} u$ a/, which occur in the prefixal set. However, since the rule of Vowel Lowering affects only noun class preprefixes so that initial $i$ and $u$ will always be followed by $i$ and $u$ respectively, this could be regarded as a dissimilation, for example, if a functional explanation is desired. It is important to maintain the distinction between state and process in explanation, a distinction which is obscured in much of Katamba's analysis. This distinction is discussed further in Section 3.

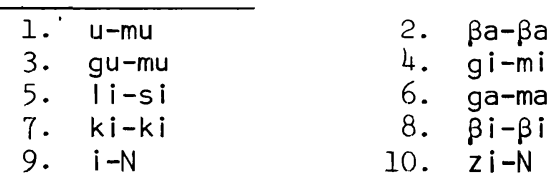

In all classes, except Class 1 , the preprefix is identical to the pronoun preceding the verb [Brown 1972:15-16]. Brown notes that this is consistent with Sir Harry Johnston's hypothesis that the Bantu prefix was primarily a classifier and the preprefix an abbreviated pronoun and demonstrative in the proto-language.

${ }^{2}$ The generality of such a rule could be used in an abstract analysis to argue for a synchronic prefix final /i-/ for Class 5 and $9 / 10$ prefixes. Historically, the Class 5 prefix is $* 1 j$ - and Class 9/10 *ni-/li-ni. Cf. footnote 9 . 
Katamba argues that rule (2) above points to the non-high vowel articulatory mode of Luganda. This explains why no words in Luganda may begin with high vowels although individual morphemes may, e.g. -iso 'eye' and -ungu 'vegetable marrow'. The question to be raised at this point is not whether the gap of word-initial high vowels represents a valid generalization, but rather what the explanation for that generalization may be. It does not seem that the postulation of a meta-rule constitutes an explanation in any real sense of the term. On the one hand, a meta-rule whose existence is demonstrated by only one process in the synchronic grammar of a native speaker is a rather suspect candidate for the category of "meta-rule". There is ro other process involving Vowel Lowering at work in the synchronic grammar of Luganda.

It is possible, on the other hand, to argue that Initial Vowel Lowering is not a synchronic process, especially since there is no evidence to suggest that preprefixal [e o] are underlyingly / $\mathrm{i} u /$ in the synchronic grammar. Apart from the nominal forms in which the initial consonant of the preprefix has been lost, there are few words which begin with vowels in Luganda. The only other examples would be second and third person verbal forms, e.g. ogula 'you buy', agula 'he buys'. Comparative evidence demonstrates that the o- prefix

represents a lowering t'rom an original *u-. There are, as was mentioned above, a fair number of individual morphemes with initial high vowels, but these typically derive from *j and *y. Many of the morphemes with initial mid vowels in Luganda have cognates in other languages with high vowels, and the reconstructed forms for these again indicate lowerings. Finally, it should be mentioned that final high vowels are also rare; the only notable exceptions to this generalization are the agentive suffix $-i$ and the adjective suffix $-u$, both of which derive from superclose vowels. Thus, there is good evidence to suggest, that Vowel Lowering can be invoked as a historical force in the shaping of Modern Luganda. However, the evidence for a synchronic meta-rule of Vowel Lowering is not strong, being contined to a single example, which can as appropriately be viewed as diachronic. In tact, a consideration of "secondary evidence" (cf. Dressler [1977]) also argues against 
assigning synchronic status to Initial Vowel Lowering. For example, Baganda exhibit no tendency to lower initial high vowels in second language learning. This kind of transfer would be expected if Vowel Lowering were a fact of Luganda phonology. The non-transfer of this pattern suggests that the absence of initial high vowels in the Modern Luganda lexicon may be viewed from the synchronic perspective as an accidental gap. ${ }^{3}$

The other example of Vowel Lowering cited by Katamba is a clearly historical process, not operative in the synchronic phonology. It concerns the merger of the original Bantu seven vowel system into the five vowel system of Luganda. Proto-Bantu had the seven vowels / i i e y u $\circ$ a /, which became Luganda / $i$ e $u \circ$ a/ by the following mergers : ${ }^{4}$

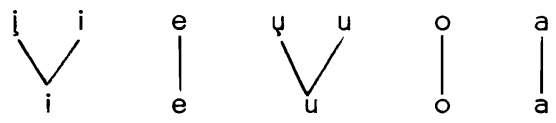

Thus, the so-called "superclose" vowels merge with the corresponding non-superclose vowels. Several points need to be noted here. First, merger in favor of any five vowel system other than that represented above would be extremely surprising, e.g. / i i 乡 u a/, /i e 乡 $\circ \mathrm{a} /$. Second, while the above reconstruction of seven vowels is solid, it has been proposed, at least informally, that this phonemic system may have

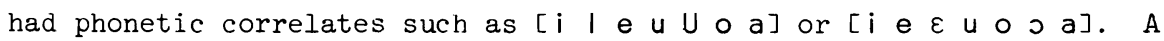
reduction of the latter system to five surface qualities would involve a merger of the non-low vowels and subsequent raising of the low vowels [Herbert 1976:115]. If this were the case, then the reduction is an instance of Vowel Raising, not Lowering. However, the issue of the phonetic values of the Proto-Bantu vowels is far from settled.

\footnotetext{
${ }^{3}$ The operation of word games, another frequently cited type of "secondary evidence", provides no information in this case since all medial syllables are $\mathrm{CV}(\mathrm{V})$ in the surface phonology, e.g. kijiiko is syllabified ki.jii.ko. Thus, a reordering of syllables will never produce initial vowels. Only idential sequences of vowels are permitted.

${ }^{4}$ The collapse of seven vowels into five is not confined to Luganda, but occurs in nearly all the Interlacustrine languages.
} 
By way of summary to the present section, it has been demonstrated that the existence of a meta-rule governing the mode of "non-high vowel articulation" in Luganda is rather suspect. The only possible synchronic example of such a rule is Initial Vowel Lowering of the preprefix, and it is far from clear what the content of the term meta-rule might be in such a case. The evidence in support of viewing the articulatory mode as a diachronic phenomenon. is certainly stronger. It needs to be remembered, however, that we are dealing in these cases with the phonetics of prehistory, and certain of the data cited in support of Vowel Lowering allow for alternate interpretation.

\section{Consonant Strengthening}

The second general principle which is said to govern the phonology of Luganda is Consonant Strengthening. There are three general processes, all active in the synchronic phonology, which are cited in support of such a meta-rule. These include: (I) the post-nasal hardening of $/ \beta \mid \mathrm{y} /$, (2) the output of Meinhof's Rule as a long nasal, and (3) the creation of geminate consonants in certain contexts. Each of these processes will be considered independently in the following sections.

3.1. Post-Nasal Hardening. Like all Bantu languages the nasal noun class prefix /N-/ of Class 9-10 assimilates in position to the following oral consonant, 5 e.g.

(4) Singular (Cl. 11)

a. Iuku

Iugalo

I usozi

lut indo

luviiri

I ufumo

$\begin{array}{ll}\begin{array}{ll}\text { Plural (Cl. 10) } \\ \text { nku }\end{array} & \text { '(piece of') firewood' } \\ \text { ngalo } & \text { 'finger (s)' } \\ \text { nsozi } & \text { 'hill(s)' } \\ \text { ntindo } & \text { 'stair (s)' } \\ \text { mviiri } & \text { '(a) hair' } \\ \text { mfumo } & \text { 'legend (s)' }\end{array}$

${ }^{5}$ This statement is not quite accurate since some languages no longer have a nasal in the class $9 / 10$ prefix. However, all languages with a nasal prefix exhibit assimilation of the nasal to the following consonant. The loss of the prefix-final /i-/ is very old, going back to Proto-Bantu. 
(4) cont.

$\begin{array}{lll}\text { b. Iuyola } & \text { njola } & \text { 'groove(s) in carving' } \\ \text { lulagala } & \text { ndagala } & \text { 'plantain leaf/leaves' } \\ \text { lußili } & \mathrm{mbili} & \text { 'palace(s)' }\end{array}$

In addition to position assimilation of the nasal prefix, the forms in (4b) also exhibit post-rasal hardening of the oral consonant. This hardening, Katamba claims, is part of the larger phenomenon of Consonant Strengthening. The same process occurs after the first person singular subject marker $/ \mathrm{N}-/$, e.g. $/ \mathrm{N}+$ laba/ ndaba 'I see', /N+yitaba/ ñjitaba'I respond'. This process is well-established, and for $/ / \mathrm{y} /$, it is not possible to argue that $\left[\begin{array}{ll}1 & y\end{array}\right]$ are simply the products of weakening since $[d j]$ also occur in this position: ludikya 'child's word game', lujegere 'chain', ndaliza 'I embroider' (cf. kudaliza 'to embroider'). However, whether the process also produces [b] of [mb] is open to question since the traditional analysis of the consonant system posits /b/. In fact, [b] and [ $\beta]$ are in free variation everywhere except postnasally where only the former may occur. This alternation has been treated in terms of a variable rule elsewhere [Herbert 1974] where the likelihood of $[\beta]$ is increased in less formal speech. The consultants upon whose speech the present researches are based had $[b]$ as often as $[\beta] .6$ This existence of $/ \beta /$ would be somewhat surprising in Luganda since the velar member of the voiced series is clearly $/ \mathrm{g} / .^{7}$ This counters the general expectation that the velar position is a "weaker" articulation, i.e. we would expect $/ \beta /$ only in the presence of $/ \gamma /$ in Luganda. There is no phonetic justification for $/ \gamma /$, however. In any event, postnasal hardening is clearly part of the grammar of Luganda, affecting at least $/ / \mathrm{y} /$.

${ }^{6} \mathrm{My}$ two major consultants are both natives of Kampala. It is possible to arrange the probability of $[\beta]$ in a hierarchy or scale of increasing likelihood [Herbert 1974:31]:

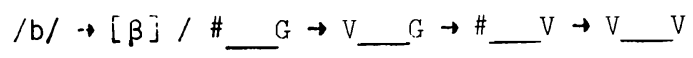

There is no parallel hierarchy for $/ / \mathrm{y} /$, e.g. / / is [d] only postnasally and when geminated.

${ }^{7}$ For the speech of my consultants, /g/ exhibits no tendency toward spirantization although Katamba [1974] mentions such a tendency for his own speech. 
The question then is whether the post-nasal hardening of $/ / \mathrm{y} /$ can be invoked as evidence for a language-specific phonetic mode favoring strong consonants. Several points bear on such a determination. First, the hardening of post-nasal / / y/ is very nearly universal when the nasal-oral sequence is to be realized as aprenasalized consonant, i.e. a unitarticulation exhibiting the surface duration of asingle consonant. In a survey of hundreds of grammars, no convincing cases of unit $\mathrm{nl}$ or $\mathrm{ny}$, where the $\mathrm{y}$ is not simply a secondary articulation, were found. Cases of unit $[\mathrm{m} \beta]$ are extremely rare as are many other nasal-continuant sequences. One of the very few examples of [n $\theta$ ] is that of Sherbro, cited by Ladefoged [1968:47]. The existence of [n $\theta$ ] is especially surprising since Sherbro also exhibits the fricatives $/ f \vee s /$, and none of these occur prenasalized. Interdental fricatives are rather rare as a class of sounds, however. Kikuyu has /ð/, but no [nð] since nasals are obligatorily deleted before all continuants; Kamba exhibits surface [nð] though.

What is surprising about Luganda, if indeed it is govererned by a meta-rule of Consonant Strengthening, is that prenasalized / $\mathrm{mf} \mathrm{mv}$ ns $\mathrm{nz} /$ all exist and exhibit no tendency toward strengthening. In a few languages, all consonants are hardened and voiced after nasal consonants so that there is a complete neutralization of oral consonants at each point of articulation in this environment, e.g.

(5) $\left\{\begin{array}{l}/ N+b i \\ i N+P / \\ / N+v / \\ / N+\beta / \\ / N+f i \\ / N+w /\end{array}\right\} \quad \rightarrow \quad[\mathrm{mb}]$

pointing to the unmarked status of nasal plus voiced stop sequences. However, this is a relatively infrequent situation. In some languages, the hardening is taken only as far as affrication. Thus, for example, $/ N+f / \rightarrow[m p f]$. The essential point of the present discussion is that Luganda hardens only / / y/, consonants which are almost universally hardened, but does not harden /f $v s \mathrm{z}$, which hardening would support 
the notion of meta-rule if it did occur.

3.2. Meinhof's Rule. The second process invoked by Katamba as evidence for the principle of Consonant Strengthening is the operation of Meinhof's Rule, also known as the Ganda Law. This rule has been the subject of much discussion which does not concern the present argument. The effect of the rule is to nasalize /b / y g/ when they occur as the oral component of a prenasalized consonant when a nasal occurs in the next syllable:
(6) $/ N+$ bengo' [mmengo] 'grind stones (cf. lubengo 'grind stone') $/ N+l i m i /$ [nnimi] 'tongues' (cf. Iulimi 'tongue') $/ N+$ yingilal [ññingila] 'I enter' (cf. kuyingila 'to enter') $/ N+$ gaana/ [ppaana] 'I refuse' (cf. kugaana 'to refuse') However, as Meussen [1963:25] has pointed out, the rule affects only /b 1 y g/ which can be traced to Common Bantu. 8

As has been discussed in previous treatments of Meinhof's Rule, Luganda is rather special in the operation of the rule in that the output is a long, i.e. geminate, nasal of which the first member is syllabic in initial position. Compare forms from Lamba, where the output is a simple nasal:

$$
\text { (7) } \begin{array}{rll}
/ i+N+\text { Bango/ } & \text { [imango }] & \text { 'bonds' } \\
/ i+N+\text { Bansa/ } & {[\text { imansa }]} & \text { 'tattoo' } \\
/ i+N+l \varepsilon m b o / & {[\text { inembo }]} & \text { 'courtyards' }
\end{array}
$$

The distinction ir outputs is explained by the fact that most Bantu languages have a general process $N N \rightarrow N$, which Luganda does not, e.g. Lamba $/ N+$ nat $+e / \rightarrow[$ pat $\varepsilon]$ 'let me snarl', Luganda $/ N+$ nool $+e / \rightarrow$ [pnoole] 'let me disapprove'. Thus, whereas other languages systematically

${ }^{8}$ There are extremely few exceptions to this generalization. Brown [1972:165-66] notes that in the Manjiya dialect of Lumasaaba, Meinhof's Rule applies to $/ \beta \mid y /$ as well as to voiced non-stops produced by a general weakening rule from $/ p+k /$, e.g. $/ i+N+p i m a /$ imima 'hyena', /i $+N+$ temu/ inemu 'snake'. Manjiya is innovative in this respect and the other Southern dialects preserve the order: 1. Meinhof's Rule, 2. Weakening. For a general discussion of the facts of Meinhof's Rule, see Herbert [1977b]. 
eliminate NN sequences, such sequences are processually produced in Luganda. Of course, this reflects the more general face that all consonants have geminated counterparts in Luganda unlike most Bantu languages. Thus, NN occurs within single morphemes as well, e.g. -mma 'grudge, withhold', -ñño 'tooth', -kinnimba 'walk proudly', -wannana 'give each other'. It would therefore be surprising for Luganda to simplify geminate nasals which appear as the output of Meinhof's Rule. The more surprising fact, and the most convincing evidence for a Consonant Strengthening mode, is the occurrence of geminate consonants in Luganda, regardless of their source.

\subsection{Geminate consonants. One of the most remarkably non-Bantu} features of Luganda phonology is the occurrence of surface geminate consonants. Historically, most of the present-day underlying geminates can be traced to sequences $* / j \mathrm{C} /$, e.g. * $-j \mathrm{j} \beta-$ 'steal' Luganda -bba , * $j+t a b i$ 'branch' Luganda -ttabi. In fact, the synchronic realization of the Class 5 noun prefix $(<* \mid j)$ is a gemination of the initial consonant: ${ }^{9}$

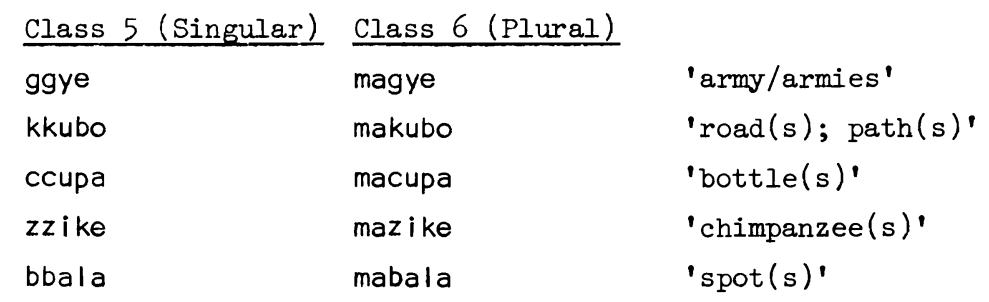

Long nasals also arise from the operation of Meinhof's Rule and also by prefixation of $/ \mathrm{N}-/$, the Class 9-10 prefix, to a nasal-initial stem, e.g. mmuli 'reeds' (cf. lumili 'reed').

9The fact that the prefix vowel was originally /i/ is demonstrated by the fact that the preprefixal vowel is /e/. Cf. Section 2. Also in a very limited set of marked stems beginning with a prenasalized consonant or a geminate consonant, the Class 5 prefix is $/ I \mathrm{i}-/$, e.g. I iñño 'tooth', I iggwa 'thorn'. Also before vowel-initial stems the prefix is ly-, e.g. Iyemvu 'ripe banana'. 
Katamba notes that long segments are marked and their existerice in Luganda points to the fact that a language may override the supposedly universal bases of markedness theory when it is governed by an articulatory mode counter-predicted by that theory. With regard to the geminates of Luganda, Katamba [1974:159] claims that "markedness theory would predict that they should be lost in the course of language change." However, contrary to universal predictions, the geminates of Luganda are not only stable, but are also produced by recent innovation. The innovation in question concerns another case of prefixal vowel loss, viz. the /u/ of the infinitive prefix / ku-/ so that there are the following alternations:

Standard dialect
kukola
kukima
kugoba

$\begin{array}{ll}\text { Innovating dialect } & \\ \text { kkola } & \text { 'to work' } \\ \text { kkima } & \text { 'to fetch' } \\ \text { ggoba } & \text { 'to drive away' }\end{array}$

i.e. the prefix vowel is deleted and / $k-/$ assimilates to the following consonant, thus producing a surface geminate。 In the dialect reported in Katamba [1977], this innovation occurs only before non-nasal velarinitial stems, 10 but Katamba [1974] notes that his younger brother also has forms such as ppima 'to weigh' (kupima), ttema 'to chop' (kutema), ssala 'to divide' (kusala)。

A phonetic explanation for this innovation is not hard to find. It has been documented elsewhere that the prefix vowels of Luganda are "extra short" in duration [Herbert 1974]. Given the articulatory similarities of $/ \mathrm{k} /$ and / $/$, it is not surprising that the prefix /ku-/ might be realized as a strengthening of non-nasal velars。The spread of this process to non-velar stems represents rule generalization, which may ultimately result in a morphological reanalysis of the infinitive prefix as /(o) C-/。

10 The restriction that the process applies only before non-nasal velars is absent if the prefix does not directly precede the verb root [Katamba 1974] :
$/ k u+b a+\mid a b a /$
bbalaba
'to see them'
$/ \mathrm{ku}+\mathrm{mu}+\mid \mathrm{aba} /$
mmu laba
'to see him' 
The real issue is not, however, how these geminates arise, but the fact that they arise at all. It has already been mentioned that this leads Katamba to accept Lass' [1972] rejection of the universal bases of markedness theory in favor of language-specific markedness, i。e. geminate consonants are not marked in Luganda hecause Luganda phonology is dominated by a particular articulatory principle. If it were not, we should expect geminate consonants to be lost rather than increase. Lass' theory is discussed in greater detail in Section 4. It will suffice to point out here that markedness theory does not claim that geminate consonants will never develop in the course of a language's history or that they will quickly die out in the course of linguistic evolution. Rather, it claims that such sounds are "less favored". It predicts that a context-free change from geminate to simple consonant should be common whereas the reverse process:

$$
\mathrm{C}_{\mathrm{i}} \rightarrow \mathrm{C}_{\mathrm{i}} \mathrm{C}_{\mathrm{i}}
$$

should be uncommon. The Luganda case does not fit the above schema; the "spread" of the geminate consonants poses no problems for markedness theory since it does not result from the spontaneous strengthening of normal consonants。

3.4. Summary. By way of provisional summary, Katamba's three examples of Consonant Strengthening have been examined in some detail. The case of post-nasal hardening was inconclusive since not all consonants are hardened in this position and the hardening of // y/ in this environment is a near-universal process. Obviously, a process which is universal can have no value in arguing for a language-specific phonetic mode. Even if the process were merely inherited from Proto-Bantu, it can have no more value in this regard than it can in arguing for the degree of genetic relatedness of two languages.

Meinhof's Rule, the second of Katamba's examples, was shown to be an instance of geminate consonants. The existence of geminates in Luganda is an uncharacteristically Bantu trait. The question is whether the existence of such a trait is in itself evidence for a phonological meta-rule. All of the geminates of Luganda. can be traced 
to either a diachronic or synchronic sequence of segments. It would seem that the existence of geminate consonants does not really say anything about an articulatory mode unless we find a general preference for strong consonants, which we do not。ll Indeed, if anything, it would seem that the opposite approach to the question of articulatory mode may be more profitable in this situation. That is, in languages which systematically eliminate surface sequences of consonants, regardless of their source and whether they carry morphological information, there may exist better evidence for a phonological principle governing the CV structure of these languages. However, there are some general conceptual problems with the notion of meta-rule as well as the notion of "family universal", some of which are reviewed below.

\section{Family Universals}

The theory of markedness in generative phonology is an attempt to establish a universal evaluation measure for phonology which is based on an assumption of "intrinsic content" assigned to every phonological feature. In addition to specific marked and unmarked values for features, the theory as articulated by Chomsky and Halle [1968] and Postal [1968] includes a "linking" principle which relates these feature proposals to conditions on the output of phonological rules. This theory claims that a universal phonological structure of rules converts abstract marked and unmarked values into a less abstract matrix consisting of + and - specifications. It is claimed that for every feature in every context one such feature value is "natural" and costless, the other "unnatural" and with a cost [Postal 1968:167].

The various types of considerations which are methodologically involved in the assignment of marked and unmarked values are well-known

${ }^{11}$ In fact, there are several natural assimilatory processes which regularly give marked segments, e.g. vowel nasalization:

$$
\mathrm{V} \rightarrow[+ \text { nasal] / [ [nasal }]
$$

However, these changes always occur in a restricted environment and the increase in marked segments is therefore modest. It would not be profitable to argue that languages with such natural rules are governed by meta-rules of Vowel Nasalization. 
[Greenberg 1966]; they include such data as statistical frequencies, diachronic mergers, synchronic neutralizations, etc. However, it is important to remember that the considerations as a group represent only a class of observations. In this sens, there is nothing "intrinsic" about the theory of markedness as a theory of conterit. The theory is one of observation and therefore probability:

Accepting such a theory commits one to determining for each feature value in each context grounds for a nonarbitrary choice of $M$ or $U$ representation。o. Such a theory does not claim that in every case the Unmarked phonetic element will actually appear in the position of neutralization. It claims only that this will be the case in the majority of instances since, if it is, no special language particular rule is required。

[Postal 1968:168]

The critical value of such a theory is significantly weakened, not by the infrequent instances in which its predictions do not obtain, but rather by the total lack of explanation which is incorporated into the theory. For example, it is known that the unmarked value for nonback vowels is [-round]. This is captured in the formulation proposed by Chomsky and Halle [1968:405]:

$$
[\alpha \text { round }], \rightarrow\left\{\begin{array}{ll}
{[\alpha \text { round }] / \overline{[\alpha \text { back }]}} & {[-1 \text { - }]} \\
[- \text { round }] / \overline{[+10 w}]
\end{array}\right\}
$$

That is, vowels which are $\left[\begin{array}{l}\text {-back } \\ \text {-rourid }\end{array}\right]$ are in some sense less costly than those vowels which are specified as $\left[\begin{array}{l}\text {-back } \\ \text { +round }\end{array}\right]$. There is no explanation for this fact within the theory. As Postal points out [1968: 170-71], we may hope that physiological and perceptual investigations will ultimately provide evidence for the assignment of $M$ and $U$ values。 Lass [1972] has examined this particular proposal concerning the roundness of vowels in detail and attempted to show that in some language families, e.g. Germanic, marking conventions for vowel roundness reduce to a statement of very weak probabilities. Lass claims on this basis that marking conventions have no predictive value in such cases since the "more costly" grammars of Germanic languages with front rounded vowels function as well as those of Germanic languages without such 
vowels and as well as the grammars of language families in which the convention is almost absolute, e.g. Bantu。 There is no explanation for the failure of marking conventions in Germanic. Therefore, Lass is 1 ed to reject markedness theory in its universal form and to substitute family-specific conventions。 12 The only alternative is to inject content and explanation into the original theory; this does not seem realizable at the moment.

It is clear, as Lass maintains, that markedness theory fails rather severely as a theory of intrinsic content. However, it does represent a successful prelude to such a theory. It has been demonstrated elsewhere [Herbert 1977a] how content is to be injected into the foundation of the theory in certain instances in a non-arbitrary fashion and the true explanatory value which results therefrom.

Lass' basic objection to the current theory is that it fails to reconcile meta-theoretical considerations of simplicity with languageinternal economy of individual phonological systems. Markedness theory claims that front rounded vowels, clicks, geminates, etc, will be rare among the languages of the world. How then, Lass asks, are we to reconcile these universal considerations with the sound systems of Swedish, Zulu, and Luganda? According to the theory, not only should unmarked segments be favored in synchronic neutralizations, but they should predominate in diachronic developments as well。 Lass interprets this to mean that unmarked sounds will always gain ground at the expense of the marked sounds and that new marked sounds will not develop. Of course, such was not the serious intent of the theory; this would be equivalent to claiming that all phonological evolution is directed toward the development of an optimal sound inventory consisting of a single consonant and single vowel. In this case, all linguistic utterances would have the phonetic shape $[p a \beta a \beta a . .$.$] . Nevertheless, Lass goes on at$ great length in his discussion of front rounded vowels to demonstrate

${ }^{12}$ Although the fact that there are any exceptions should invalidate the family-specific generalizations proposed by Lass. For example, Kiyanzi, a Bantu language cited by Welmers [1973:21], contrasts front rounded and unrounded vowels / $\mathrm{i}$ e $\ddot{i} \ddot{o} \ddot{u}$ u o a/. 
that they do indeed persist and develop anew in Germanic. Lass' choice of this example is less than felicitous, however. In addition to the coloration of these vowels, other considerations such as length and tenseness play an important role in their history, Thus, the interaction of various features is more complex than Lass presents.

Lass' dismissal of the theory on these grounds as being devoid of any interesting theoretical considerations seems a bit hasty, In the following section it will be demonstrated that even for language inventories which are highly marked in generative terms, the theory is not devoid of content. The case to be considered is not that of front rourided vowels in Germanic, but another cited by Lass several times, viz, the click sounds of Southern Bantu.

\section{Clicks in Bantu}

The basic assumption of the present discussion is that the click sounds are indeed marked segments. 13 They occur only in certain restricted Southern Bantu languages and in Khoisan, from which they were originally borrowed into Bantu. On the one hand, the fact that Zulu and other languages should have incorporated clicks into their phonological systems is a point which weighs heavily against markedness theory. Historically, we know that Bantu had no clicks and that they were introduced during a period of particularly intense sociological contact in which Khoisan women were taken as wives by the invading Bantus. Larham [1964:383] describes the system of polygamy practiced by the Bantus and notes that the father was only an "occasional visitor" to his families. Therefore, the greater influence during the child's early years was that of the mother, and it was only later that the influence of the father and the extended family began to be felt. This type of situation differs considerable from the canonical varieties of language contact, which may explain the extraordinary linguistic results.

13 The unmarked airstream mechanism is the pulmonic egressive one. That is, glottalic egressive (ejectives), glottalic ingressive (implosives), and the velaric (clicks) are all marked mechanisms. It is unclear what, if any, is the relative markedness of the latter three types. 
For example, fully 17 of the present 47 consonant phonemes in Zulu were introduced from Khoisan. Lanham places the original contact between the Bantu and Khoisan peoples between five and seven centuries ago。 This is the point of departure for the following discussion.

Were we to assume an unmarked status for the click sounds in Nguni, for example, we would have no way of accounting for the reduction of click oppositions in many languages since other consonant oppositions make use of the same points of articulation. There are five click types in the Khoisan languages:

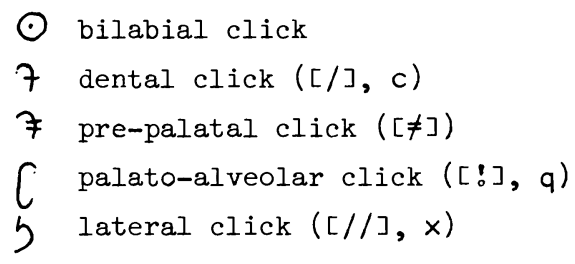

All the Bushman languages exhibit four types, but the labial click occurs rather infrequently [Bleek 1939]. We do not find any Bantu language which makes use of the full range of oppositions.

Zulu and Xhosa exhibit the most extensive incorporation of clicks into sound inventories. Both languages distinguish three main click types: the dental click, palato-alveolar click, and the lateral click。 Lanham [1964:382] reports that fully one-seventh of Zulu words and onesixth of Xhosa words contain clicks。 These are, of course, mainly words which are borrowed from Khoisan. Bantu words which exhibit clicks come mainly from the hlonipa vocabulary。HIonipa (also hlonipha) is a process whereby taboo words undergo various phonetic alterations。 These alterations include the substitution of:

(13) a. a non-click for a non-click

b. a click for a non-click

c. a click for a click

d. a non-click for a click

Faye [1923-25] provides a detailed discussion and numerous examples of the process.

Pedi [Stopa 1960:23] is reported to distinguish two clicks: the 
pre-palatal and a retroflex fricative. Ziervogel [1952:8] reports a contrast between the dental and palato-alveolar types in Swazi. Thus, Zulu amaxolo 'bark' may be found in Swazi as emacolo, Emaqolo, Emagcolo, Emagqolo. However, Stopa and Lanham both claim that Swazi has a single click type, which is substituted for all other varieties. Similarly, in Sutho [Tucker 1929:63] there is only one click, the palato-alveolar, and in the other Sutho-Tswana languages the clicks have disappeared entirely。

Knowing, as we do, extremely little about the routes and chronology of click incorporation into various Bantu languages, we might attempt to explain the number of types in any language as an inverse function of the directness of borrowing. That is, those languages which borrowed directly from Khoisan should exhibit the greatest number of distinctions and those which borrowed via other Bantu languages should show reduced inventories. This would constitute an argument supporting the marked status of the clicks, albeit a rather weak argument. Such an argument would, of necessity, make socio-historical claims about contact which cannot be substantiated since we are dealing with pre-history. Additionally, a much stronger argument in favor of the marked status of clicks in Bantu would be forthcoming if we suppose that languages may previously have had a wider range of clicks than they evidence at present. This would be especially powerful since we know of no cases of languages independently increasing the number of clicks in their inventories.14 of course, just as there is no evidence that the clicks were introduced indirectly into some languages, there is no evidence that all the Bantu click languages previously had the full series of clicks or even the number of oppositions presently displayed in Zulu. However, there is evidence that at least some languages have reduced their click inventories and that in some languages the clicks have been eliminated entirely. Stopa [1960:23] cites Elmslie's observation that among the older Ngoni

${ }^{14} \mathrm{~A}$ fundamental difference is assumed between languages without clicks incorporating them into their sound systems and languages with click sounds increasing their inventories. 
[sic] people, all the clicks are attested as in Zulu. Apparently, the dental click replaced the other types in normal speech and a "new dialect" appeared which had various combinations of consonants as substitutes for clicks. In Northern Transvaal Ndebele, there are no clicks, but older language consultants "remember times" when clicks were used in speaking [Ziervogel 1959:33]. A very f'ew plant names still show the clicks, e.g. mugqugols, nqaxi. For the most part, however, this dialect of Ndebele has non-click sounds corresponding to clicks in other languages. For example, [kx'] is the normal development of Bantu *nk, but there are cases pointing to $\left[k x^{\prime}\right]$ as the development of the palato-alveolar click, symbolized as $q$ in the Zulu orthography: (14)

$\begin{array}{lll}\frac{\text { Ndebele }}{\text {-kx'wala }} & \text { Zulu } & \\ -\varepsilon \eta k x ' \varepsilon l a & -q a l a & \text { 'begin' } \\ -k x^{\prime} e d z a & -\varepsilon q a & \text { 'jump over' } \\ - \text { likx'anda } & -q \varepsilon d a & \text { 'get finished' }\end{array}$

Similarly, a nasal click is most often represented as [o] in Ndebele:

\begin{tabular}{|c|c|c|}
\hline$-\operatorname{man} \varepsilon$ & $-n \operatorname{can} \varepsilon$ & 'small' \\
\hline - & $-\varepsilon n \times \varepsilon \tilde{n} \varepsilon$ & 'elsewhere' \\
\hline -not'ula & -nqodula & 'pull out' \\
\hline
\end{tabular}

There are no known cases of the reverse substitution, i.e. of clicks for non-clicks in normal linguistic evolution. 15

Notice that this type of evolution is exactly what markedness theory would predict. Lass claims that there is nothing "unnatural" about clicks in Zulu, voiceless lateral affricates in Nahuatl, front rounded vowels in Swedish, etc. Yet, we have seen that Lass' notion of family universal cannot be maintained. Clicks may be "natural" in some Southern Bantu languages in that they exist in these languages; in this regard markedness theory is not a theory of "naturalness evaluation". The grammars of Zulu and Xhosa work as well as the grammars of non-click

15 It has already been mentioned that the only candidate for such a substitution is hlonipa. 
Bantu languages. However, the evidence points to the clicks being more "complex", more "costly", or simply secondary in those languages where Lass claims they are natural.

The marked value of clicks is evidenced not only in diachronic ievelogments. .m. and dialectal varieties of Zulu, the clicks are replaced systematically by other consonants and that the lateral click is aisappearing in general. Also, clicks are among the last sounds acquired by Zulu children, being replaced by the corresponding non-clicks [Louw 1964; A. Nkabinde, personal communicationJ. In fairy tales, the speech of animals, usually represented as baby talk, is devoid of clicks [Jakobson 1958:35].

\section{Conclusion}

On the whole, Lass' notion of family universal and languagespecific markedness seems to contribute little to the solution of the general questions which markedness theory was designed to address. Lass claims that for non-click languages like English and Chinese, the clicks are neither marked nor unmarkea; they are simply not part of the inventory, i.e. they are like teeth in chickens. Similarly, there is nothing unnatural about clicks in click languages; these languages are simply "that kind of beast". However, the evidence presented in Section 5 clearly points to the clicks being marked in the Southern Bantu click languages. ${ }^{16}$ It would be difficult to explain the data of diachronic developments, synchronic replacement, child phonology, etc. otherwise. This points to an inherent difficulty in Lass' revision of markedness and would seem to be a vindication, on a rather small scale,

16 Even in those languages where clicks are original elements, Bushman and Hottentot languages, there are distributional restrictions on the occurrence of clicks [Greenberg 1970:67]. Bleek [1939:61] reports that many Bushman words with clicks coexist with clickless variants and that certain words with clicks in the speech of older speakers have lost these clicks with the younger speakers. Finally, she observes that "most words that are very often in use such as pronouns, demonstratives and verbal particles, have no clicks in all the languages" indicating a "tendency to drop the clicks." 
of the more orthodox tieory of markeaness. Despite the explanatory gap in the theoretical foundation or the theory, its predictions are borne out by the synchronic and diachronic language data.

Similarly, the Lugarıda data concerning geminates do not represent a significant inaictment of markeảness theory. As was snown in section 3.3, all the geminates are attributable either diachronically or synchronicaliy to an original sequence of segments. 'That Meinhof's Law and the process of infinitive prefix reduction give rise to surface geminates is not surprising since geminates are otherwise an important part of the Luganda sound system. What requires explanation is the fact, that Luganda tolerates surface geminates, regardless of their source.

Katamba attempts to explain the presence of geminates by reference to the articulatury mode of the language. However, as was demonstrated in section 3, the only evidence for the mode of Consonant Strengthening is the existence of geminate consonants. Thus, the reasoning involved in the anaiysis is inherentiy circular: the geminates exist because of a particular phonetic mode and the evidence for the phonetic mode is the existence of geminates. Similar reasoning is involved in the justification of the phonetic mode of Vowel Lowering.

I do not mean to suggest here that the concept of articulatory mode is inherently devoid of content. Obviously, this issue cannot be decided on the basis of data drawn from a single language. It seems plausible that the phonology of a language might be governed by general preferences for certain types of phonetic outputs in the same way that several processes in a language may corspire to produce CV syllable structure. However, the question is then how many processes define a meta-rule. Two? Three? Seven? It would not seem that the existence of a single process or single state can be used to argue for such general principles. In the absence of any theory of intrinsic content or an explanation for the existence of geminates in Luganda, all we can do at present is to note that Luganda is "that kind of beast", or, to make further use of Lass' metaphor, geminates in Luganda are like gizzards in chickens, i.e. simply part of the inventory. 
Bleek, D.F. 1939. "A short survey of Bushman languages." Zeitschrift für Eingeborenen Sprachen 30:52-72.

Brown, Gillian. 1972. Phonological kules and Dialect Variation. Cambridge: The University Press.

Chomsky, Noam and Morris Halle. 1968. The Sound Pattern of English. ivew York: Harper and kiow.

Dressler, Woifgang. 1977. "Morphologization of phonological processes." in A. Juilland (ed.), Linguistic Studies of fered to Joseph Greenberg, pp. 313-37. Saratoga: Arima Libri.

Faye, C.U. i92j-2'. "The influence of 'Hlonipa' on the Zulu clicks." Bulletin of the School of Oriental and African Studies 3:757-82.

Greenberg, Joseph H. 1966. Language Universals. The Hague: Mouton.

Greenberg, Joseph H. 19\%. The Languages of Africa. Bloomington: indrana Unıversity Research Centre in the Language Sciences.

Herbert, Robert K. 1974. "Selected topics in the phonology and acoustic siructure of Luganda." Unpublished M.A. thesis, Ohio State University .

Herbert, Robert K. 1976. "A reanalysis of Luganda vowels: evidence for an abstract distinction." Afrika und übersee 59:113-24.

Herbert, Robert K. 1977a. "Language universals, markedness theory, and natural phonetic processes: the interactions of nasal and orai consorants." Unpubiished Hh.D. dissertation, Ohio State University.

Herbert, Robert K. 197\%b. "Phonetic analysis in phonological description: prenasalized consonants and Meinhof's Law." Lingua 43:339-73.

Jakobson, Roman. 1958. "What can typological studies contribute to historical comparative linguistics?" Proceedings of the Eighth International C'ongress of Linguists, pp. 17-35. Oslo: 0sio University Press.

Katamba, Francis $z$. 1974. "Aspects of the grammar of Luganda." Unpublished Ph.D. dissertation, University of Edinburgh.

Kataruba, Francis. 1977. "Un meta-rules in phonology." Studies in African Linguistics 8:33-47.

Ladefoged, Peter. 1968. A Phonetic Study of West African Languages. Cambridge: The University Press.

Lanham, L.W. 1964. "The proliferation and extension of Bantu phonemic systems influenced by Bushman and Hottentot." Proceedings of the Nintir International Congress of Linguists, pp. 383-391. The Hague: Mouton.

Lass, Roger. 1972. "How intrinsic is content? Markeaness, sound change, and "family universals'." Edinburgh Working Papers is Linguistics $i: 4 \hat{c}-67$. [Also in D.L. Goyvaerts and G.K. Pullum (eds.), Essays on the Sound Pattern of English, pp. 475-504. Ghent: Story-Scientia, 1975.] 
Louw, J.A. 1964. "The consonantal whonemes of the lexical root in "Zulu." Afrıka und Übersee 48:127-52.

Meeussen, A.E. 1963. "Meinhof's Kule in Bantu." African Language Studies 3:25-29.

Postal, Paul. 1968. Aspects of Phonological Theory. New York: Harper and kiow.

Stopa, Roman. 1960. The Evoiution of Click Sounds in some African Languages. Kraków: Nakładem Universytetu Jagiellıńskiego.

Tucker, A.N. 1929. The Comparative Phonetics of the Suto-Chuana Group of Bantu Languages. London: Longmans, Green and Co. [Reprinted 1969. Farnborough: Gregg International Publishers.]

Welmers, Wm. E. 1973. African Language Structures. Berkeley: University of California Press.

Ziervogel, D. 1952. Grammar of Swazi. Johannesburg: Witwatersrand University Press.

Ziervogel, D. 1959. A Grammar of Northern Transvaal Ndebele. Pretoria: J.L. van Schaik, Ltd. 



\author{
WHAT' SORI' OF' 'IONE: LANCUACE' IS MENDH:?* \\ David Dwyer \\ Michigran State University
}

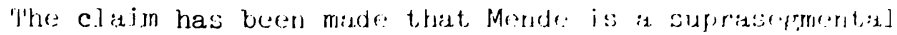
torse languagre requiring an independent ropresentation of tomis and segmential information in the lexicon. (m)ly in thi:s wisy, it is claimed, can the true nature of Mende tene be urederstood: that the surfiace tonal patterre; of Mrende rian be reduced to t’jve baisic uriderlyine melodies (L, H, l,ll, l,ll, l,Hl,). Arpunents, buth syrehronic and diachronie, are prosernted in this paper which demonstrate that this arady:siaj j:s incorrect and that Mende is not such is tonal larsuape. Insisciad, an alternative "tersion" model, based on an autosconment,isl model, has been proposed which demorstrates how the relevirnt lid ta of the language, both synchrouje: and diachronic, cart be most adequately explained. 'l'be paper does not claim that supr:asegmerital languages do rot exist, rather that, Mende jis rut, such a tone language, thereby refining, the notion of what is a suprasegmental tone lariguage.
\end{abstract}

\title{
1. Introduction
}

The question raised in the title of this paper is not asking simply for the specific inventory of tonal types and processes of the Mende grammar but rather the principles by which these inventories are shaped. Such principles, if they exist and when they are correctly identified, will not only lead to the answer of this taxonomical question "what sort of tone language is Mende?" but will also lead more directly to a descriptively adequate analysis of the language under consideration.

*This paper is a rewritten version of a manuscript originally presented to the Seventh annual conference on African linguistics (University of Florida, April, 1975) entitled "What is a supra-segmental tone language?" This latter version has profited from the comments from a number of scholars, but particularily from Herbert Stahlke and from William Leben. 
One such answer to this question has been proposed by Leben [1973] who claims that some languages, including Mende, require a different type of lexical representation; one in which the phonological information is separated into two distinct and completely autonomous components. For Mende the tonal "melody" is stored in the "suprasegmental" component and the remaining phonological information in the segmental component. At some point in the derivation of the phonetic form of these morphemes, these tones are assigned to the tone-bearing segmental units according to a set of formal tone-mapping rules. After this mapping process, these languages function in the same way as others which do not have this "suprasegmental" lexical component, such as Thai and Chinese.

Thus while all tone languages are "segmental" in this sense, not all tone languages are "melodic". Implicit in this taxonomy is the claim that melodic tone languages require a more complex formalism because they exhibit properties which cannot be adequately explicated in "non-melodic" terms. Leben has repeatedly claimed for example that Mende is such a language requiring a melodic analysis and partially on the basis of this claim, he has made a case for the general validity of the melodic hypothesis. Yet there is evidence that Mende does not support these claims. In this paper, the predictions of the "melodic" proposal are compared against an alternative proposal which claims that the tones of Mende are never completely independent of the supporting segmental string.

\section{Two Theories of Tone}

2.1. The nature of the suprasegmental "melodic" claim. Specifically the suprasegmental proposal claims that the observed segmental patterns in Mende can be accounted for by positing five suprasegmental tonal melodies. These melodies ( $, \mathrm{L}, \mathrm{HL}, \mathrm{LH}, \mathrm{LHL}$ ) are termed suprasegmental because they describe the segmental tonal patterns of Mende morphemes regardless of number of syllables. At some point in the derivation, these tones are mapped onto the segments producing segmental tone patterns according to a set of specific tone-mapping principles. The following have been proposed by Leben [1973:65] for Mende:

(1) a. If the number of level tones in the pattern is equal to or less than the number of vowels in the word possessing the pattern, put 
the first tone on the first vowel, the second on the second, and so on; any remaining vowels receive a copy of the last tone in the pattern.

b. If the number of level tones in the pattern is greater than the number of vowels in the word possessing the pattern, put the first tone on the first vowel, the second on the second, and so on; remaining tones are expressed as a sequence on the last vowel available.

(2) a. Tone Melody Number of syllables in morpheme

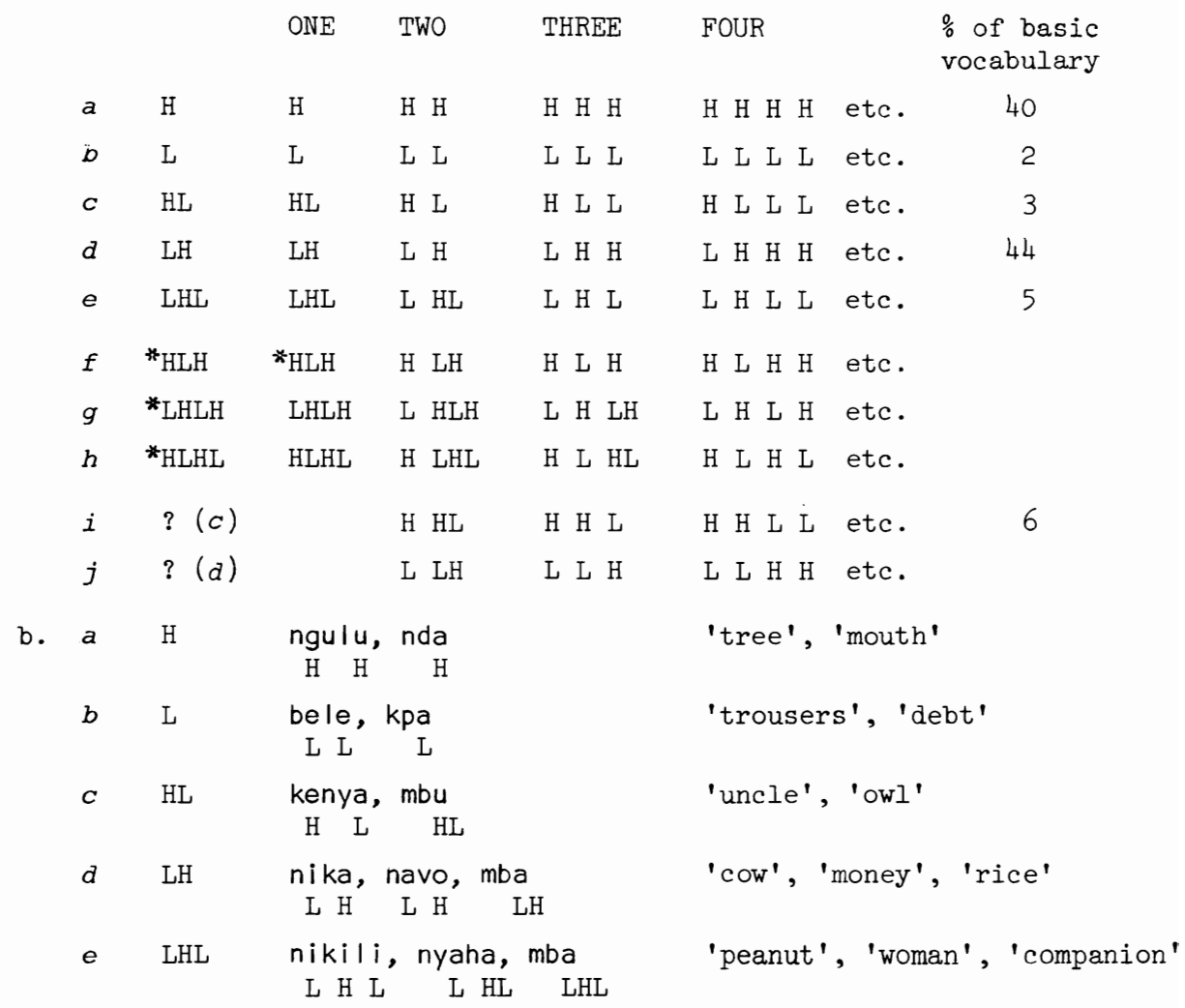

Given these procedures, the five Mende melodies will be mapped onto morphemes of various syllable length producing the segmental patterns $a, b$, $c, d$, and $e$ of (2a). Examples from Mende of these tone patterns are given in $(2 b)$. According to the theory, segmental patterns $f, g$, and $h$ will not be produced, because these tonal melodies do not exist in the language, and patterns $i$ and $j$, while corresponding to the melodies HL and LH respectively, 
cannot be derived by the existing tone mapping rules.

Given the formalism of the suprasegmental proposal, it is possible to make three specific predictions, (3), about the nature of Mende tonology which a corresponding segmental theory could not:

(3) a. that certain tone patterns do occur which are not likely to be predicted by segmental theories (see section 3.1);

b. that certain tone patterns do not occur in Mende because they reflect a constraint against an underlying tone melody (these non-occurring patterns are defined here as "structural gaps", see section 3.3 );

c. that certain segmental tone patterns do not occur in Mende because they are expressly and intentionally forbidden by the way in which the theory was formulated (these proposed non-occurring patterns are defined as "formal gaps", see section 3.2).

These claims contrast with those of a less radical, non-melodic hypothesis of Mende tonology, an example of which is given in 2.2 .

Because there are a variety of possible proposals for the representation of tone, both segmentally and suprasegmentally, I prefer to label this particular suprasegmental proposal by its principal characteristic, the melodic claim. Henceforward this theory shall be termed the "melodic" hypothesis.

2.2. The tension-based alternative. In contrast to the suprasegmental melodic hypothesis, I would like to put foreward a competing hypothesis which asserts that the tonal information of a word is never completely disassociated from the segmental information of a word. This alternative proposal if correct does not claim that Mende is not a suprasegmental tone language, only that Mende is not a suprasegmental tone language of the type described in 2.1. As mentioned earlier, this alternative is not incompatible with other "suprasegmental" models such as that put forward by Goldsmith [1975, 1976] which claim a closer relationship between tone and segment. The essential aspect of this alternative claim, (4) is that the tonal patterns can only be understood in relation to the segmental string.

(4) In an underlying representation, any tone-bearing ([+ syllabic $]$ ) segment must be assigned at least one, but not more than two distinct tones. 
Thus the possible tone patterns for any syllable are four, given in (5a). Tone patterns specifically prohibited by this statement are given in ( $5 b)$.

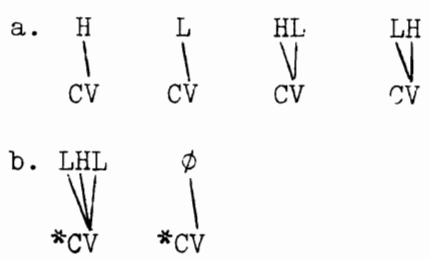

Given this hypothesis, the number of tonal patterns of Mende words is a simple function of the number of syllables in the string. This means four possible monosyllabic tone patterns, sixteen possible disyllabic tone patterns and so on. Because this alternative is based on the permissable relationships between tones and tone-bearing segments, I have termed it the "tension" hypothesis.

\section{The Suprasegmental Claim and the Data}

This section compares evidence from the synchronic tone patterns of Mende in order to test the accuracy of the suprasegmental claim that all Mende tone patterns are attributable to five underlying tone melodies. On the basis of the evidence, it is shown that none of the predictions given in (3) can be sustained and therefore that the melodic hypothesis is likewise unsupportable.

3.1. Three tones on a single syllable. One of the predictions made by the suprasegmental tone hypothesis is that if a suprasegmental melody exists, it ought to be manifested on morphemes of any given syllable length. On the basis of disyllabic morphemes such as ngètê 'pestle' and trisyllable words such as nikili 'peanut' the melodic hypothesis would claim the existence of a LHL melody (see (2)). Furthermore, since this LHL melody is found on disyllabic and trisyllabic morphemes, it ought to be found on monosyllabic morphemes as well. The alternative hypothesis (2.2), on the other hand, strictly prohibits three tones from occurring on a monosyllable (see 4b)). Thus the issue of a short vowel with a LHL tone pattern is of great importance in determining which of the two hypotheses under consideration here is an accurate reflection of the data.

Leben provides one example from Spears [1967] of a purported threetoned monosyllable: mbàâ 'companion'. However, this example is contestable 
for a number of reasons. First, the morpheme is transcribed by Spears with two vowels although Spears clearly states that the use of two vowels does not "necessarily" indicate length and that the use of two vowels is often used as an orthographical tone-marking device.

A second reason for contesting the LHL claim for Mende monosyllables is the fact that Innes [1969] records the contested morpheme with a long vowel. This is not true only for 'companion' but for every example listed in Spears [1967] as $c \hat{v} \hat{v}$ and which also appears in Innes [1969]. Furthermore, my own data agrees with Innes in this regard. Thus there is no clear evidence that this morpheme is short and some solid evidence to indicate that it is long.

Finally this form is cognate with Kpelle bārân and was presumably present in Proto Southwestern Mande, also as *bärân. The anticipated Mende reflex of this proto form should be *mbàla (based on the rules given in Dwyer [1974]). The loss of a medial I to produce mbàa (with a long vowel) is a common Mende rule (see Spears [1967]) and for that matter a common Western Mande rule (see Welmers [1975]). Were the loss of the medial I to become obligatory as is often the case, the Mende reflex of this morpheme would be mbàa (with a long vowel). Leben was aware of this problem as the following quote indicates:

"If the vowel is long, this still does not affect my argument insofar as the argument seeks to establish that the permissable and impermissable tone patterns are the same as for other words. If $\mathrm{mba}$ originates synchronically from a disyllable, then another instance of a monosyliable with a LHL would have to be sought." [Leben 1973:50]

Yet there appear to be no uncontestable examples of such morphemes in Mende, and, I would venture, no such examples in Mende.

3.2. Structural gaps. The claim that there are no HLH patterns in Mende is representative of the sort of restrictions that are statable under a suprasegmental framework. This claim incorporates the segmental statements that the sequences $\mathrm{HLH}, \mathrm{H} \mathrm{LH}$, do not exist in Mende, with the implication that these non-occurrences are the consequence of a single underlying structural gap. This claim could be successfully refuted by showing either that such tone melodies do occur, or that the particular gaps in question are a fortituous collection of gaps which are the consequence of other events. 
The non-melodic alternative explains the absence of a HLH pattern in a monosyllable as a consequence of the constraint against three different tones appearing on the same tone-bearing segment, the same constraint that prohibits LHL monosyllables. The alternative hypothesis, does not prohibit HLH sequences in trisyllabic morphemes, and ample evidence is available to support not only HLH patterns, but also HLHL patterns as is shown in (6) below.

a. HLH patterns
yámbùwú 'tree ( $\mathrm{sp})$ '
Iánsàná proper name
IÉnà
b. HLHL patterns
náfàlê 'raphia clothed clown' njéngùlû 'tarantula' dúmbèékà 'star'

In addition to the above clear-cut examples of the HLH and the HLHL tonal patterns, there are a number of other examples involving a downstepped high tone (marked here as $' H$ ) which could be interpreted as counter-examples to the proposed HLH constraint because the surface downstepped high tone could have been derived from an underlying or historical HLH or HLHL melody. This argument is elaborated on in section 6.

A second possible source for the sequence of $\mathrm{H}^{\prime} \mathrm{H}$ is suggested by the morpheme vód'nú 'last year' because this form is rendered in my transcriptions as vóònú with a long initial syllable. Spears [1967] has pointed out for Mende a rather common west African rule, called LOW RAISING by Hyman and Schuh [1974] which raises a low tone between two high tones to a downstepped high tone, e.g. vóònú $\rightarrow$ vóónú and gbúeí $\rightarrow$ gbúél 'yesterday'.

3.3. Formal gaps. The prediction of formal gaps is a consequence of the form of the suprasegmental theory of tone representation. Specifically, formal gaps result from the condition that a given melody can be mapped onto a sequence of tone-bearing segments in only one way. Thus the claim that a language has only five possible suprasegmental tone melodies predicts that Mende monosyllabic morphemes will exhibit only five tonal patterns, that Mende disyllabic morphemes will exhibit only five tonal patterns and so on. The form of a particular pattern is a consequence of the particular melody it represents and the proposed mapping rules. 
Patterns $i$ and $j$ of ( $2 a$ ) are formal gaps in Mende because they cannot be derived from the patterns $\mathrm{HL}$ and $\mathrm{LH}$ from the existing tone mapping rules. While it is possible to redefine the tone mapping rules in order to incorporate $i$ and $j$, this redefinition of the mapping rules would automatically render tone patterns $c$ and $d$ of (2a) as formal gaps. This is, after all, the intent of the suprasegmental melodic theory.

The coexistence of two competing sets of tone patterns, in Mende either $c$ and $i$ or $d$ and $j$, would contradict the predictions of a suprasegmental tone theory and force the conclusion that Mende is not amenable to this analysis. The following list of morphemes representing both $c$ and $i$ and $d$ and $j$ tonal types, based on Spears [1967], provides the apparent counterexamples to the claim that Mende is a suprasegmental tone language.

(7) pattern illustrated by $c$

kálì 'hoe'
ngílà 'dog'
ngámà 'eye'
kúsì 'cushion'
mbélà 'father', 'brother-in-law'
kpúlò 'bird (sp)'
kpówò 'shout'
félàmà 'junction'
wóòmà 'back'
mólìmò 'Muslim'
kúhàmà 'far away'
kóbàà 'northern rice'
híinà 'that is so'

pattern illustrated by $d$ pattern illustrated by $i$

$\begin{array}{ll}\text { kónyô } & \text { 'friend' } \\ \text { hókpô } & \text { 'navel' } \\ \text { mbémbê } & \text { 'circle' } \\ \text { náhî } & \text { 'so that' } \\ \text { pókô } & \text { 'imitate' } \\ \text { tókplâ } & \text { 'anus' } \\ \text { ngóngô } & \text { 'tooth' } \\ \text { séwúlò } & \text { 'rodent (sp)' } \\ \text { kókólì } & \text { 'seek' } \\ \text { géógbè } & \text { 'absolutely nothing' } \\ \text { símbíti } & \text { 'spider' } \\ \text { wúámà } & \text { 'faint' } \\ \text { kpóngbóni } & \text { 'palsy' } \\ \text { símént i } & \text { 'cement' } \\ \text { lóólù } & \text { 'five' } \\ \text { náni } & \text { 'four' }\end{array}$

bj̀ndó 'okra'
nàvó 'money'
gbèhé 'bench'
bèté 'plasas'
bùbá 'dashiki'
ndèndél 'shade'
ndàvúlá 'sling'
bèésí 'pig'

pattern illustrated by $j$

$\begin{array}{ll}\text { nìkă } & \text { 'cow' } \\ \text { pèlě } & \text { 'path' } \\ \text { kàlỳ } & \text { 'snake' } \\ \text { kpity } & \text { 'grass' } \\ \text { mahǎ } & \text { 'chief' } \\ \text { lèlèmá } & \text { 'praying mantis' } \\ \text { fààlé } & \text { a name } \\ \text { kòlòbé } & \text { 'none' } \\ \text { làsimó } & \text { 'amulet' }\end{array}$


The underlying representations of the disyllabic patterns $d$ and $j$ in (7) above are considered by Leben to all represent pattern $d, e \cdot g$. LH and their different surface alternations are considered to be governed by a diacritic feature.

3.4. Possible suprasegmental explanations of the counterexamples. The data presented thus far have been termed "apparent counterexamples", because there are a number of arguments which could be used to resolve the contraditions. These include (1) faulty transcriptions, (2) morphological complexity, (3) borrowing, and (4) statistics.

3.4.1. Reanalysis. Leben has noted that words having a segmental tone pattern of the type LH H, e.g. běsí 'swine', cannot be transcribed by the existing tonal rules, which would predict *bèsí. However, the problem can be remedied if the initial vowel is treated as long, bèsí. The LH tone melodies will be correctly mapped on to the segmental tonebearing segments. To this Leben [1973:85] remarks, "It is not clear whether these vowels are phonetically short." Here Leben is referring to the fact that the rising tone of this morpheme is transcribed by Spears with two vowels but that this fact does not indicate that the rising tone is necessarily long. My own transcriptions show these rising tones to be long. This problem was also encountered in section 3.1. However, contesting the length of the vowel in these examples automatically weakens the claim of shortness in morphemes such as mbàa .

3.4.2. Morphological complexity. To be sure, many of the examples found in the Mende lexicon are morphologically complex, though Spears [1967] made every effort to identify entries which were obviously morphologically complex, so that the remaining examples, if they are morphologically complex, are not completely convincing. For example, the word séwúlò 'cutting grass' (a rodent resembling a groundhog) represents a possible example of a morphologically complex word. While a convincing meaning cannot be Identified for sé, wùlǒ might be identified as the morpheme 'little'. In support of this analysis is the observation that the tone pattern of this word is what would be anticipated were it a normal compound, e.g. sé+wùlǒ $\rightarrow$ séwúlò (in this paper, the two boundary symbols + and - are 
used to mark compound divisions and affixes respectively). However, until convincing meanings can be established for each element of the compound, and the resultant meaning of the compound shown to be derivable from the individual constituent meanings, the tone patterns displayed by séwúlo and the like must be considered legitimate examples which must be reckoned with by any empirical based theory of tone.

A word such as kpóngbónì 'palsy' is also suspiciously complex, although I have been unable to identify any of the possible constituent morphemes. If we consider this word to be entered into the lexicon as morphologically complex, i.e. kpóngbó-ni, then it is possible to explain why this particular example is an exception to the predictions made by the suprasegmental hypothesis. Yet allowing any apparent counterexample to the suprasegmental hypothesis to be broken into smaller tonally acceptable constituents without the supportive evidence to suggest that these constituents are morphemes can only serve to weaken the suprasegmental position even further for it will no longer be possible to provide counterexamples to the theory which cannot be explained away through ad hoc morphologizing.

A related problem concerns reduplicated (or apparently reduplicated) morphemes such as ngóngô 'tooth'. Leben analyzes these as compounds, e.g. ngó+ngó $\rightarrow$ ngó+ngô. This analysis presents two problems. First, if this word is a true compound composed of two occurrences of the morpheme ngó, then the second occurrence of the morpheme ng ought to begin with a weak consonant, e.g. *ngóws . Secondly, morphemes referring to body parts do not undergo tonal changes when in compounds.

Historically, the development of a H HL disyllabic tone pattern appears to have been the result of the loss of a final vowel of a trisyllabic word, e.g. $\mathrm{H} \mathrm{H} \mathrm{L} \rightarrow \mathrm{H}$ HL $\phi$. The body parts 'tooth' and 'nose', transcribed by Spears as ngóngô or ngóngóli and hókpô respectively, are transcribed by Innes as ngóngóu and hókpóù (and apparently represent a slightly different dialect). If indeed these H HL patterns represent reduced trisyllabic words, then the reduplication analysis is diachronically incorrect and in view of the other synchronic objections which have been raised against the analysis of these words as reduplicants, this analysis appears to be equally incorrect synchronically. 
It will be recalled that the original intent of the reduplicative analysis of these words was to explain the occurrence of a tone pattern $\mathrm{H}$ HL which the suprasegmental hypothesis expressly excluded, and given that the reduplicative analysis is incorrect, then either a new explanation will have to be sought or the suprasegmental hypothesis abandoned. For example, the suprasegmental hypothesis could be maintained if the above examples were analyzed according to the supposed diachronic development, e.g. ngóngó-ù, except that the deleted vowel is represented lexically as a floating low tone, e.g. ngóngó- $\phi$ in the suprasegmental notation. A rule could be written which would assign a floating low tone to the preceding syllable and as such would provide an explanation why $\mathrm{H}$ HL surface tonal patterns are not true exceptions to the claims of the suprasegmental hypothesis.

The objections to the proposed analysis parallel those of the one based on reduplication: there is virtually no synchronic evidence in the dialect described by Spears to warrant words such as ngóngô as being morphologically complex. As mentioned above, this sort of morphologizing can serve only to weaken the suprasegmental claim, for as it permits the explaining away of any complex non-conforming tonal pattern, it looses its ability to explain why other non-conforming tonal patterns such as ${ }^{*} \mathrm{H}$ LH do not occur. Secondly, such an analysis must explain why other observed complex tonal patterns should not also be analyzed in this way, such as $\mathrm{L}$ HL being derived from $\mathrm{L} H-\mathrm{L}$ and $\mathrm{LHL}$ being derived from LH-L, and for that matter ultimately from L-H-L. Because this alternative analysis presents more problems than it solves, it, too, must be abandoned leaving the suprasegmental hypothesis at a loss to explain certain complex tonal patterns that it predicts ought not to occur. Furthermore, if applied with equal rigor to all morphemes of three or more syllables, this extremely powerful and virtually unchecked type of morphologizing would eliminate practically all of the morphemes of three syllables in length or more (other than obvious borrowings) from consideration and reduce the number of trisyllabic and quadrasyllabic morphemes to such point that their tonal patterns, whatever they were, would be statistically insignificant. Thus, the impact of this kind of morphologizing is to reduce the domain of the suprasegmental melodies to monosyllabic and disyllabic morphemes, 
principally those found in Proto Southwestern Mande. This Leben is willing to do:

"The corresponding prediction involving the pattern LH applied to words of three syllables is problematic since Innes [1969] gives a number of instances of words with the prohibited contour and $I$ have been unable to find an adequate way of analyzing these." [Leben 1963:67]

The elimination of morphemes of more than two syllables reduces the predictive power of the suprasegmental claim severely, for the number of tonal combinations of $\mathrm{H}$ and $\mathrm{L}$ in one and two syllabled words is considerably less than that of a system also containing morphemes of three and four syllables and therefore much less distinct from the predictions of the alternative claim.

\subsubsection{Borrowing. Although many of the tonal counterexamples to the} suprasegmental theory can be dismissed through a plea to morphological complexity, this is not possible with borrowings. Borrowings such as síménti 'cement' would not be treated as morphologically complex (even if they were) by the borrowing language. Yet, this morpheme cannot be assigned a tonal pattern by the existing mapping mules. To change the existing rules to permit HHL morphemes would as argued above automatically exclude certain morphemes with a HLI tone pattern. Thus, the tonal patterns displayed by borrowings, which parallel those of non-borrowings, provide incontrovertible evidence that the tonal patterns of Mende cannot be accomodated by only five underlying tonal melodies.

While it is tempting to preserve the suprasegmental claim by weakening it slightly by proposing that borrowings belong to a special class ana are subject to different rules, such proposals are extremely unrevealing. For example, one might propose that these morphemes, because they are borrowings involve a different tonal mapping mule, possibly related to penultimate stress such that for English borrowings, high tones are assigned from left to right up to and including the penultimate syllable and a low tone is assigned to the ultimate. This rule seems applicable to a number of morphemes, (8a), but clear counterexamples also exist as well, $(8 b)$. 
(8) a. kópà 'penny' siméntì 'cement' pláímínísà 'prime minister'
pénsù 'pencil' hóspítù 'hospital'
lámbù 'lamp'
b. kòfí 'coffee' máísí 'match'
mikì 'milk'
sùkù

The absence of a consistent pattern among English, or other borrowings for that matter, makes the argument about borrowings belonging to a special class untenable.

3.4.4. A statistical argument. It is also possible to weaken the claim, as Leben is prepared to do [personal communication], that while the melodic hypothesis does no', apply to $100 \%$ of the lexicon, it does account for roughly $90 \%$ of the Mende basic vocabulary and therefore the suprasegmental claim ought to have some validity.

In response to this, a number of comments are worth making. First, the $90 \%$ figure relates to the basic vocabularly only, reflecting what I claim in section 6 to be an historical fact. Were the entire lexicon to be included in the pattern/frequency count, the patterns described by the suprasegmental melodies would constitute a much lower percentage.

Secondly, and more importantly, this $90 \%$ claim is considerably weaker than the original claim since it is now impossible to provide counter examples to the proposal; it is only possible to quibble about the percentage of entries which fall within the melodic claim.

Thirdly, originally Leben established a dichotomy between segmental languages (those which do not have a suprasegmental melodic component) and suprasegmental languages (those which do). Now there appear to be languages which are only partly suprasegmental, having some lexidal entries with suprasegmental tone and some lexical entries with segmental tone.

Finally, it is now unclear how this weakened suprasegmental melodic claim differs from the alternative tension-based claim, since both hypotheses assert that the tonal patterns in Mende are diverse. What does the melodic claim now reveal about the nature of Mende tone that the non-melodic claim does not? This issue will be taken up in section 7 . 


\section{Implications of the Counterexamples}

On the basis of the data presented in tuis section, a number of important conclusions can be drawn. First, it has been shown that the constraint against HLH melodies in Mende is false. Since the issue concerns the correctness of a constraint, it would hardly appear to be a serious criticism of the suprasegmental position, yet, upon further examination this is not the case.

First, the elimination of the constraint against HLH melodies creates a new problem for the suprasegmental position, for now there is no reason why a HLH melody cannot be mapped onto a morpheme of one syllable, yet there are no uncontested examples of any monosyllabic morphemes with more than two tones. From a suprasegmental standpoint, the lack of such examples, as well as the parallel lack of monosyllabic morphemes with a LHL melody, cannot be explained.

A second problem caused by the elimination of the constraint against the HLH melody arises from the fact that the *HLH constraint is the only substantial suprasegmental gap that could be found in Mende. Thus the loss of this constraint virtually eliminates the ability of the suprasegmental theory to make any true, relevant statements of structural tonological gaps in Mende. While it might be possible to make a claim against a LHLH or a HLHLHL melody, the theory would be competing with a segmental theory in explaining why four to six tones could not appear on a single tone-bearing unit for mono- and disyllables on one hand and would take advantage of the paucity of morphemes of three or more syllables to explain gaps on the other. The fact that the theory can make no unique claims of structural gaps does not destroy that theory, but it does considerably weaken its descriptive value.

A second criticism of the theory concerns what I believe to be the false prediction of three tones occurring on a single tone-bearing segment. While the existence of such a tone pattern would constitute a very strong supportive argument in favor of the suprasegmental position, the lack of such a tone pattern likewise weakens this position for now it is at a loss to explain this gap as anything but an accident unless it puts forward an additional constraint against more than two different tones being assigned to the same syllable thus incorporating the essence of the non- 
melodic alternative. Were this to be done, two things would happen. First, the number of unique predictions of the melodic hypothesis would be reduced. Second, the melodic theory would have to become more complex and less distinct from the competing alternative model.

The final and most crucial criticism, however, concerns the formal gaps predicted by the suprasegmental theory. The theory was constructed in order to make the co-occurrence of certain tonal patterns such as $\mathrm{HHH}$ and HLL impossible (because only one of these segmental patterns can be derived from an underlying melody in a given language). The existence of both patterns in Mende is clear indication that the formalism of the suprasegmental theory excludes Mende as a suprasegmental tone language.

Clearly from this evidence, the claim that Mende is a language with five underlying melodies is unsubstantiated, and an alternative explanation to Mende tonal phenomena must be sought. In the next section, those aspects of Mende tone which are thought to be synchronically relevant are presented from a segmental point of view. The following section provides a diachronic explanation for those facts which are not considered to synchronically relevant.

\section{The Tension Hypothesis and the Data}

In this section, the predictions of the tension hypothesis are compared with the data. As pointed out in section 2.2, this hypothesis predicts four monosyllabic tone patterns, sixty-four trisyllabic tone patterns, etc.

5.1. Monosyllabic tone patterns. The tension hypothesis predicts four and only four monosyllabic tone patterns, specifically those given in (3a). Mende displays precisely these four monosyllabic tone patterns, (9). See section 3.1 for arguments against a possible fifth monosyllabic tone pattern.

(9) $\begin{array}{lll}\text { H } & \text { nda } & \text { 'mouth' } \\ \text { L } & \mathrm{kpa} & \text { 'debt' } \\ \mathrm{HL} & \mathrm{mbu} & \text { 'owl' } \\ \mathrm{LH} & \mathrm{mba} & \text { 'rice' }\end{array}$

While the complex tones of this series rarely appear on the surface as complex, reflecting a Mende constraint against surface-level complex tones, 
both analyses agree that these complex tones do exist in these underlying representation. The basis for this claim is that these complex tones exhibit phonological alternations, which are given in (10a) with examples given in ( $10 \mathrm{~b})$.

(10) a. 1) utterance finally (before \#)
2) before a low-toned segment (before L)
3) before a high-toned segment (before H)

\begin{tabular}{|c|c|c|c|c|}
\hline b. & $\begin{array}{l}\text { underlying } \\
\text { representation }\end{array}$ & $\begin{array}{l}\text { surface } \\
\text { before \# }\end{array}$ & $\begin{array}{l}\text { surface } \\
\text { before L }\end{array}$ & $\begin{array}{l}\text { surface } \\
\text { before } H\end{array}$ \\
\hline $\mathrm{H}$ & ndá & $\begin{array}{l}\text { ndá } \\
\text { 'mouth' }\end{array}$ & $\begin{array}{l}\text { ndá-fèlé } \\
\text { 'two mouths' }\end{array}$ & $\begin{array}{l}\text { nd } \varepsilon-i \\
\text { 'the mouth' }\end{array}$ \\
\hline L & kpà & $\begin{array}{l}\text { kpà } \\
\text { 'debt' }\end{array}$ & $\begin{array}{l}\text { kp̀à-fèlé } \\
\text { 'two debts' }\end{array}$ & $\begin{array}{l}\text { kpغ̀-l' } \\
\text { 'the debt' }\end{array}$ \\
\hline $\mathrm{HL}$ & mbû & $\begin{array}{l}\text { mbû } \\
\text { 'owl' }\end{array}$ & $\begin{array}{l}\text { mbú-fèlé } \\
\text { 'two owls' }\end{array}$ & $\begin{array}{l}\text { mbú-l' } \\
\text { 'the owl' }\end{array}$ \\
\hline $\mathrm{LH}$ & njă & $\begin{array}{l}\text { njă' } \\
\text { 'water' }\end{array}$ & $\begin{array}{l}\text { njă-fèlé } \\
\text { 'two rivers' }\end{array}$ & $\begin{array}{l}n j \grave{k}-l^{\prime} \\
\text { 'the water' }\end{array}$ \\
\hline
\end{tabular}

5.2. Disyllabic tone patterns. The non-melodic hypothesis predicts that if four tone patterns are possible or morphemes of one syllable, then sixteen tone patterns will occur on disyllabic morphemes. These patterns are given in (1l), those which have been attested are circled.

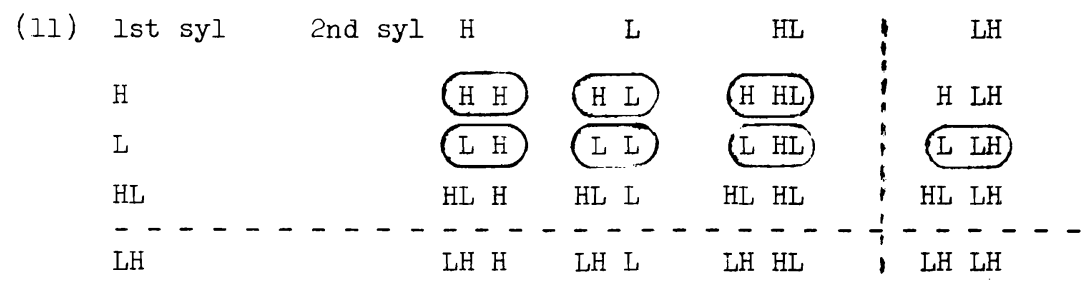

Clearly, there is a discrepancy between the observed and predicted tonal patterns. If a segmental analysis is to have any validity, it ought to provide a convincing explanation of these gaps. In the following analysis, these gaps are shown to be a consequence of two independent factors: (1) the uniqueness of the rising tone and (2) gaps caused by non-alternating complex tones. Temporarily setting aside the problem of the distribution of morphemes involving rising tones, let us turn our attention to the apparent lack of non-final falling tones. These tones have not been observed because were they to exist either underlyingly or historically, 
they would he modified by the proposed tonal rules. Since these falling tones are in a non-final position, their environment is fixed and alternation is impossible. Were the following falling tones HL H, HL L, and HL HL to function like morpheme-final falling tones, their surface manifestation would be as follows: $\mathrm{HL} H$ would appear on the surface as $\mathrm{H}$ ' $\mathrm{H}$; HL L would be indistinguishable from $\mathrm{HL}$; $\mathrm{HL} \mathrm{HL}$ would appear on the surface as $\mathrm{H}$ 'HL.

Words with these surface patterns do exist as evidenced by the morphemes tátb' 'start' and góné' 'cat', providing evidence of more tonal patterns than those given in (II). With the addition of these entries, the $3 \times 3$ inner matrix of (11) is completed as shown in (12).

\begin{tabular}{|c|c|c|c|c|c|}
\hline (12) & lst syl & 2nd syl & $\mathrm{H}$ & $\mathrm{L}$ & $\mathrm{HL}$ \\
\hline & $\mathrm{H}$ & & $\begin{array}{l}\text { ngúlú } \\
\text { 'tree' }\end{array}$ & $\begin{array}{l}\text { ngílà } \\
\text { 'dog' }\end{array}$ & $\begin{array}{l}\text { ngóngô } \\
\text { 'tooth' }\end{array}$ \\
\hline & $L$ & & $\begin{array}{l}\text { nàvó } \\
\text { 'money' }\end{array}$ & $\begin{array}{l}\text { bદેl દે } \\
\text { 'trousers' }\end{array}$ & $\begin{array}{l}\text { ngètê } \\
\text { 'pestle' }\end{array}$ \\
\hline & $\mathrm{HL}$ & & $\begin{array}{l}\text { tátó' } \\
\text { 'start' }\end{array}$ & $\begin{array}{l}\text { (same as } \\
\mathrm{H} \mathrm{L} \text { ) }\end{array}$ & $\begin{array}{l}\text { gડ่ı̂́ } \\
\text { 'cat' }\end{array}$ \\
\hline
\end{tabular}

Therefore, with the exception of the rising tone, which is severely limited in its distribution, the number of disyllabic tonal patterns is a function of the number of possible syllabic tonal types (3) and the number of syllables.

5.3. Trisyllabic tonal patterns. Again setting aside the short-rising tone, a segmental analysis when applied to trisyllabic morphemes, would predict $3^{3}$ or 27 tonal types, save for six redundancies, listed in (13d), caused by the nature of the falling tone. However, because of the limited number of trisyllabic morphemes in the language, which are not apparent reduplicated morphemes or morphologically complex (possible compounds), it is difficult to find clear manifestations of each of these tonal patterns. Nevertheless, the search for trisyllabic tone patterns revealed that in addition to the five trisyllabic tonal patterns predicted by the suprasegmental theory, (13a), Mende has seven additional trisyllabic tonal patterns, (13b), which are not predicted by the suprasegmental tone theory but which are predicted by the segmental theory. Despite the nine unattested patterns, $(13 c)$, which must be viewed as accidental gaps, the 
observed data is clearly more in line with the predictions of the segmental theory than with the suprasegmental theory.

(13) a. predicted by both the segmental and suprasegmental theories $\mathrm{H} \mathrm{H} \mathrm{H}$ fóníngé 'young man'

L L I. gòmòn 'slothín'

H L L félèmà 'junction'

L $\mathrm{H} H$ ndèndélí 'shade'

L H L fàkáli 'pawpaw'

b. predicted by the segmental but not by the suprasegmental theory

H L II lánsàná proper name (structural gap in ss theory)

H L HL kónùgû 'centipede' (structural gap in ss theory)

H HL H másì 'matches' (structural gap in ss theory)

L HL H máto' 'add to' (structural gap in ss theory)

I I H làsimó 'amulet' (formal gap in ss theory)

H H L símbitì 'spider' (formal gap in ss theory)

L L HI nòmòli 'statuette $(\mathrm{sp})$ ' (formal gap in ss theory)

c. predicted by the segmental but not the suprasegmental theory

i H HL does not occur L HL HL does not occur

$\mathrm{HL} \mathrm{H} \mathrm{H} \mathrm{does} \mathrm{not} \mathrm{occur} \mathrm{HL} \mathrm{H} \mathrm{L} \mathrm{does} \mathrm{not} \mathrm{occur}$

$\mathrm{HL} \mathrm{H} \mathrm{HL} \mathrm{does} \mathrm{not} \mathrm{occur} \mathrm{HL} \mathrm{HL} \mathrm{H}$ does not occur

$\mathrm{HL} \mathrm{HL} \mathrm{HL} \mathrm{does} \mathrm{not} \mathrm{occur} \mathrm{H} \mathrm{H} \mathrm{HL}$ does not occur

$\mathrm{H}$ HL iLl does not occur

d. redundant tone patterns

$\mathrm{H} \mathrm{HL} \mathrm{L} \mathrm{same} \mathrm{as} \mathrm{H} \mathrm{H} \mathrm{L}$

L HL L same as $\mathrm{L} H \mathrm{H}$

HL HL L same as HL H L

$\mathrm{HL} \mathrm{L} \mathrm{H} \mathrm{same} \mathrm{as} \mathrm{H} \mathrm{L} \mathrm{H}$

HL L L same as H L L

$\mathrm{HL} \mathrm{L} \mathrm{HL} \mathrm{same} \mathrm{as} \mathrm{H} \mathrm{L} \mathrm{HL}$

5.4. The distribution of the rising tone. From the data presented so far, it is clear that the distribution of the polarized (rising tone) is nonrandom. As originally pointed out by Spears [1967] this tone is always 
preceded by a low tone, a fact which the segmental theory has failed to capture. There is a reason for this, although it is not synchronically relevant. In the next section, the peculiar distribution of the polarized tone is seen to be a simple consequence of the historical evolution of Western Mande.

6. The Historical Evolution of Southwestern Mande (SWM) Tone Classes

6.1. Tone classes. The tonal patterns described by Leben's five tonal melodies account for at least $90 \%$ of the modern Mende morphemes, and probably $98 \%$ of Proto Southwestern Mande, a fact which demands an explanation. However, in order to facilitate the discussion, I would like to reclassify the Mende tonal patterns given in (2) into the following tonal types:

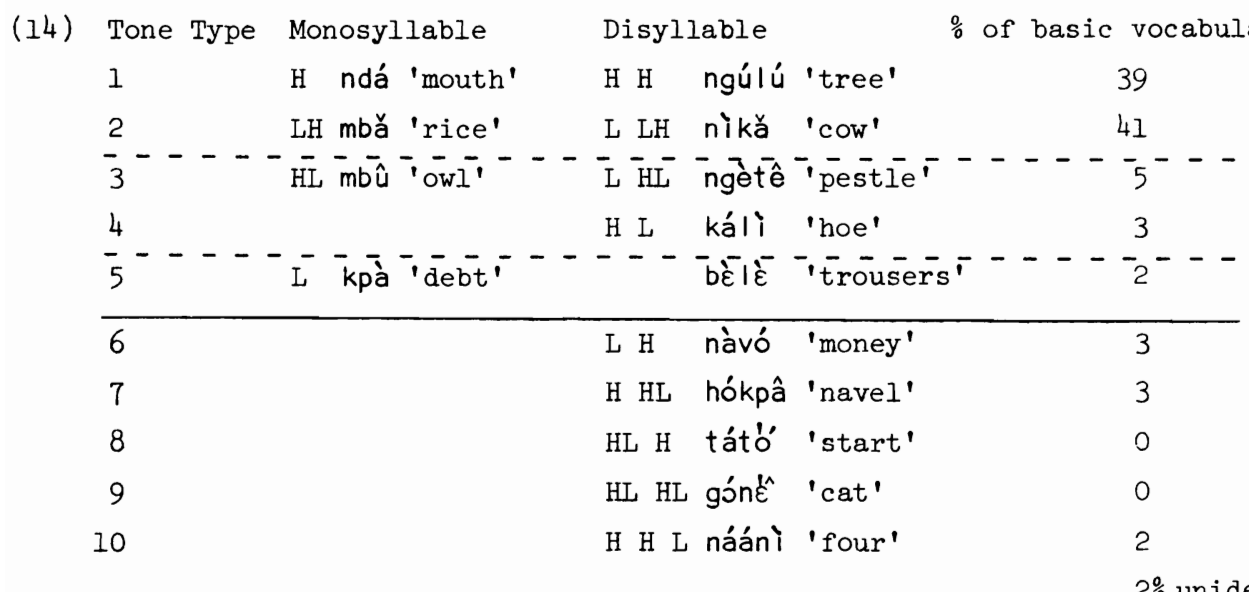

$2 \%$ unidentified

(At this stage in the discussion, the haček found over type-two words is to be interpreted as a diacritic used to mark "polarized" tones. See text for details. Section 7 argues that this tone has an underlying short-rising tone.) The numbering of these tonal classes is not arbitrary; it represents their order of appearance in Mende. Tone classes 6 through 9 include the most recent additions to Mende; they show no consistant cognates with other SWM languages, even the near dialects, Bandi and Loko.

The remaining tone classes are more frequent than the others, comprising the bulk of the basic vocabulary of Mende and demonstrating a consistent 
phonological correspondence in all the SWM languages. Therefore, these tone classes most likely comprised the tone patterns of Proto SWM. Examples of these correspondences are given in (15) below:

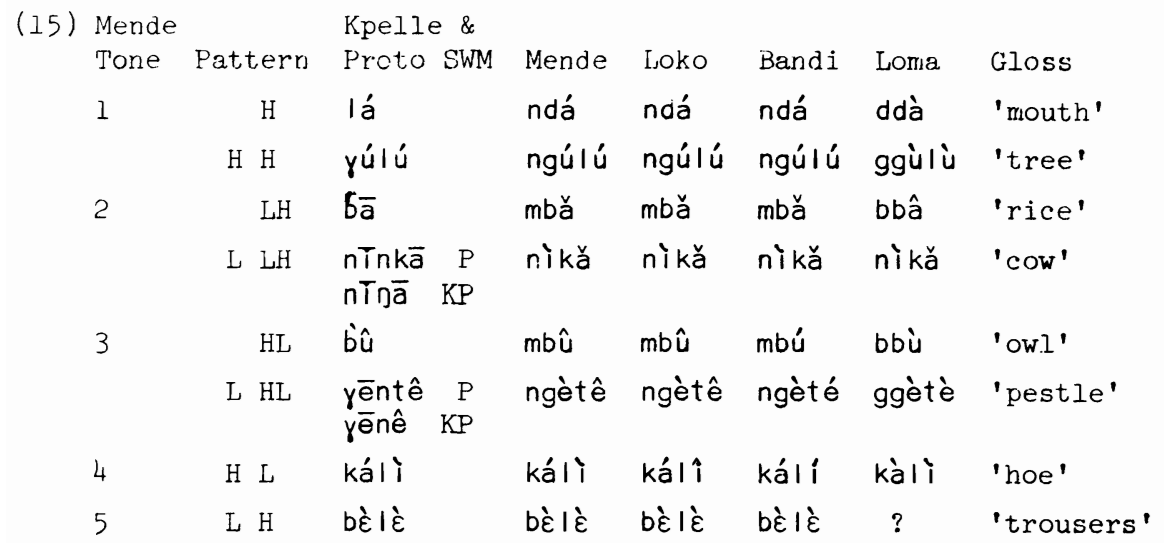

\subsection{Class 5 morphemes. Welmers [1961] clearly demonstrated that class} 5 nouns in Kpelle represent borrowings. His arguments cite both (1) phonological idiosyncracies (unlike classes 1 through 4, a large percentage of class 5 morphemes have non-mutating initial consonants) and (2) syntacticidiosyncracies (all class 5 morphemes are nouns). But class 5 nouns appear in all of the modern SWM languages, and what is more, they show the same medial consonant correspondence as do the first four noun classes, namely a Central SWM prenasalized medial consonant corresponding to a Kpelle medial nasal as shown in (16).

\begin{tabular}{|c|c|}
\hline Gloss & Mende \\
\hline 'trousers' & bદેl \\
\hline 'hat' & bذ̀lذ̀ \\
\hline 'chisel' & tònd̀̀ \\
\hline 'Sande' & sàndè \\
\hline
\end{tabular}

Morphemes more recently borrowed do not show this medial consonant development, e.g. Me lámbò , KP lámpù 'lamp'. Furthermore, the arguments used by Welmers for Kpelle can be extended to include the Central SWM languages with the conclusion that class 5 nouns as a type were present in Proto-SWM, but represent the most recently acquired tonal class. This 
hypothesis explains why this class is present in all of the SWM languages and why this class displays a medial consonant development which is consistent with the first four noun classes.

The lack of cognates between SWM class 5 nouns and Northern Mande nouns further suggests that this tonal class was acquired by Pre-Proto SWM after it separated from Northern-Western Mande. And if the nouns of class 5 are Pre-Proto SWM borrowings, then a number of the peculiar characteristics of this class become understandable, such as (1) why this class contains such a small percentage of the number of common SWM nouns, (because they are borrowings), (2) why only nouns belong to this class (borrowed words are always nouns) and (3) why words in this class begin with a stressed low tone (perhaps because they represent a new morphological class acquired through borrowing). It is also possible that since the establishment of class 5 nouns in Pre-proto-SWM that additional members of this class have been subsequently acquired through borrowing.

6.3. The mid tone. At some time after its divergence from Proto Western Mande and prior to the acquisition of class 5 nouns, Pre-Proto-SWM had only four tonal classes. At that time, the mid and low tones were in complementary distribution: low tones occurred following high tones and mid tones occurred elsewhere. The lower allotone may well have been the result of downdrift. Whatever the explanation, Pre-Proto-SWM was a language with only two contrastive phonemic tones while Kpelle has three, (17). Pre-Proto SWM Kpelle Mende

\begin{tabular}{|c|c|c|c|c|}
\hline \multirow[t]{5}{*}{ Class } & 1 & $*(\mathrm{H}) \mathrm{H}$ & $(\mathrm{H}) \mathrm{H}$ & (H) $\mathrm{H}$ \\
\hline & 2 & *(L )L & $(\mathrm{M}) \mathrm{M}$ & (L) $\mathrm{LH}$ \\
\hline & 3 & *(L) HL & (M) HL & (L) HL \\
\hline & 4 & $* \mathrm{H} \mathrm{L}$ & $\mathrm{H} \mathrm{L}$ & $\mathrm{H} \mathrm{L}$ \\
\hline & 5 & -- & L L & $\mathrm{L} \mathrm{L}$ \\
\hline
\end{tabular}

At some point between Pre-Proto-SWM and modern Kpelle a mid tone developed, e.g. *(L)L > (M)M and *(L)HL > (M)HL. When this developed is unclear although it is undoubtedly a response to the acquisition of class 5 morphemes which have the same tonal pattern as class 2 morphemes. This 
restructuring of central SWM of class 2 morphemes from LI to L LH may represent a parallel response.

6.4. Class 1 and 2 morphemes. Class 5 nouns are not the only tone class that fails to show any correlation with Northern Mande. In fact, all the cognates which have been established between these two subbranches on segmental grounds consisteritly belong to SWM tone classes 1 and 2. Furthermore, their Northern Mande reflexes display the same consistent tonal patterns with similar but not identical tonal alternations.

\begin{tabular}{|c|c|c|c|}
\hline Gloss & Reconstructed & Proto-SWM & Susu [Houis, 1963] \\
\hline 'medicine' & *sálé (1) & & sérí \\
\hline 'tree' & *wúlú & & wúrí \\
\hline 'rat' & *nyíná (1) & & nyéné \\
\hline 'root' & *sánké (1) & & sąké \\
\hline 'cow' & *ninkā (2) & & nìgé \\
\hline 'chief' & *mänsā (2) & & mągé \\
\hline 'monkey' & *küla & & kùlé \\
\hline 'chicken' & $* t \bar{e} \cdot \bar{e}$ & & tèxé \\
\hline 'bird' & 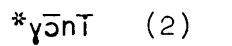 & & xòní \\
\hline
\end{tabular}

Furthermore, it has been observed that these two tonal classes represent the predominant tonal classes in Western Mande. They comprise $80 \%$ of the basic vocabulary in Mende for example. For these reasons, Proto Western Mande, the ancestor of Mende and Southwestern Mande, appears to have been a language of two tonal classes: 1 and 2. While Class 1 morphemes can be characterized as having all high tones, the characterization of class 2 morphemes, because of its phonological alternation requires further discussion.

6.5. Class 2 morphemes. The alternation of morphemes of this class takes one of two basic forms as represented by Bambara and Mende. In both languages, the final tone is $\mathrm{H}$ before a following $\mathrm{L}$ and $\mathrm{L}$ before a following $\mathrm{H}$ (hence the term polarized), but in Bambara, the tone is $\mathrm{L}$ utterance finally, while in Mende and the other central SWM langauges the tone is $\mathrm{H}$ utterance finally. 
These surface forms are given in (19) below:

$\begin{array}{cllll} & \begin{array}{l}\text { Bambara } \\ \text { disyllables }\end{array} & \text { monosyllables } & \begin{array}{l}\text { Mende } \\ \text { disyliables }\end{array} & \text { monosylables } \\ \text { Before H } & \text { L L-H } & \text { L-H } & \text { I L-H } & \text { L-H } \\ \text { L } & \text { L H-L } & \text { LH-L } & \text { L H-L } & \text { H-L } \\ \text { \# } & \text { L L\# } & \text { L \# } & \text { L H\# } & \text { H \# }\end{array}$

Because polarization appears in each branch of Western Mande, there is good reason to suppose that polarization was a fact of Proto Western Mande. Furthermore, because both branches of Western Mande exhibit the Bambara type of alternation (Kpelle for SWM) there is good reason to believe that the Bambara type of alternation represented the type of alternation found in Proto Western Mande class 2 morphemes. Therefore, the Mende type of alternation, found in all SWM languages but Kpelle, represents the innovative form. From this information Proto Western Mande appears to have been a "partially free pitch-accent system", to use McCawley's [1967] terminology, of two tonal types: type one morphemes (consisting of all high tones) and type two morphemes (consisting of a string of zero or more low tones followed by a morpheme-final polarizable tone). Furthermore, it is an important historical fact that throughout the course of its development into SWM, this polarized tone has maintained its unique association with tone class (2) despite the acquisition of new tone classes. It is these factors that account for the highly restricted distribution of the polarized tone in all the SWM languages: the polarized tone appears (1) only morpheme finally and (2) only when preceded by a non-high tone. Thus, the highly restricted nature of the polarized tone has a very understandable historical explanation.

6.6. Class 4 morphemes. Because class 4 nouns also have no cognates in Northern Mande, because of low percentages (3\% of the basic Mende vocabulary) of this class in Proto-SWM and because this tonal class shows no evidence of morphological complexity, this class, too, most likely consists of borrowed morphemes. The source of these borrowings has not been established.

6.7. Class 3 morphemes. Prior to the acquisition of class 4 nouns, the 
tonal system of an earlier stage of Pre-SWM contained only three tonal classes. Class 3 nouns also have no cognates with Northern Mande nouns, but in this case, their acquisition by SWM may not have been due exclusively to borrowing. Class 3 nouns have the tonological appearance of nominal compounds which are composed of class 1 and/or class 2 monosyllabic constituents.

The tonal rules of Proto-SWM and modern Kpelle are such that any compound composed of any combination of class 1 and 2 monosyllabic nouns would produce a class 3 tonal pattern as is illustrated in (20).

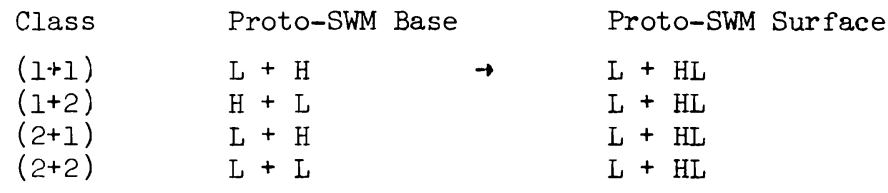

If class 3 nouns are fossilized compounds constructed from class 1 and 2 nouns, then at this stage of development of Proto-Southwestern Mande, there are only two true tonal classes: class 1, (H)H, and class $2(L) L$. This conclusion ties in very neatly with the observation that only SWM tonal classes 1 and 2 have cognates in Northern Mande.

An objection to the hypothesis that class 3 nouns are fossilized compounds is the lack of convincing morphological evidence to back it up. What evidence there is is suggestive, but not totally convincing.

The Mende examples given in (2l) suggest the possibility of being compounds although there is considerable inconsistency in the tones.

\begin{tabular}{|c|c|c|c|c|}
\hline (21) ndòpô & 'child' & ndó + po & 'child' & $?$ \\
\hline nyàápò & 'mistress' & nyàhâ + po & 'woman' & $?$ \\
\hline hì índò & 'male' & hin + ndo & 'male' & 'child' \\
\hline ndàáyà & 'spittle' & ndá + yă & 'mouth' & 'water' \\
\hline ngèéndà & 'morning' & ngèlě + ndá & 'sky' & 'mouth' \\
\hline ngèwว́ว̀ & 'God' & ngèlě + wólj & 'sky' & 'bigl' \\
\hline ndámbá & 'crocodile' & ndá + mbá & 'mouth' & $' b i g_{2}$ ' \\
\hline ng’̀mbû & 'fire' & +ngכ̌n + bù & 'fire' & 'under' \\
\hline nyàhâ & 'woman' & nyá + hâ & 'my' ? & 'female' \\
\hline nìkàhâ & 'cow' & nì kà + hâ & 'cow' & 'female' \\
\hline njòláà & 'potato leaf' & njòwǒ + láwá & 'potato' & 'leaf' \\
\hline
\end{tabular}


Some of the class 3 nouns may not be true compounds but borrowings, but because they have the tonal contiguration of a nominal. compound, they represent an acceptable surface tonal pattern in Proto SWM and could, therefore, have been borrowed with that tonal pattern as a "pseudo" compound.

Whatever the explanation of the origin of class 3 nouns, they do not, as far as can be determined, have cognates in any of the northern Mande languages and therefore must have been acquired since Northern-Western Mande split into Southwestern and Northern Mande.

At the time of this split, then, there were two tone classes: class 1, * $(\mathrm{H}) \mathrm{H}$, and class $2{ }^{*}(\mathrm{~L}) \mathrm{L}$ (with the final polarizing tone). The development of the third tonal class is closely linked to the tonal patterns of nominal compounds. Either the class 3 tonal patterns, (L)HL, represent fossilized compounds, or the tonal patterns of nominal compounds may have broken the constraint that morphemes are all high or all low, thereby paving the way for class 4 words, *HL, and class 5 words, *LL, with true low tones. The development of the five SWM tone classes from Proto-Northern-Western Mande is summarized in (22) below with the percentages of representation of the first 5 types in the Mende basic vocabulary.

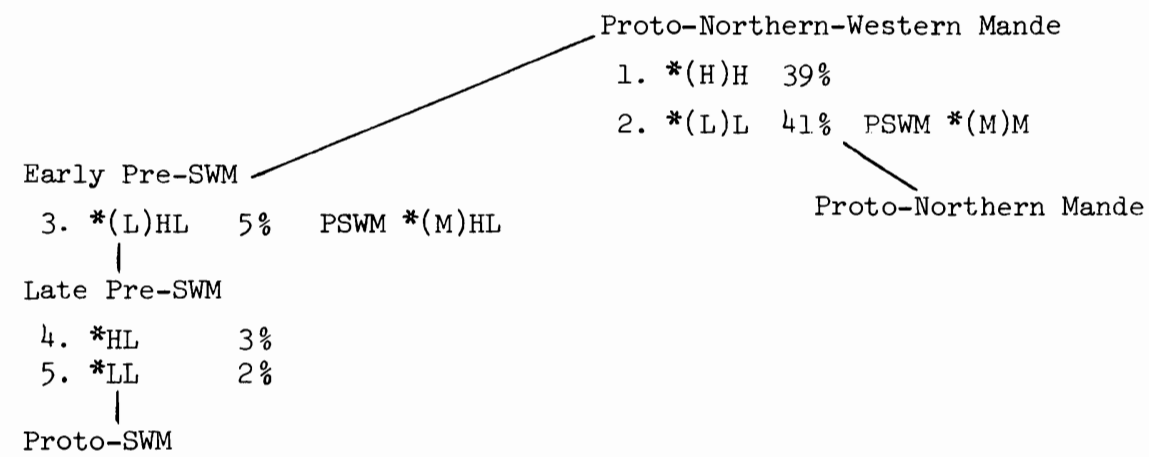

This analysis does not include the development of morphemes of more than two syllables for the reason that no consistant cognates either within SWM or between the two branches of Western Mande have been identified. Thus, it is reasonable to conclude that trisyllabic morphemes largely, if 
not completely, comprise borrowings, a fact supported by their relatively small numbers in these languages ( $4 \%$ in the basic vocabulary).

Yet although the tonal patterns Leben claims for Modern Mende are incomplete, they appear to be a more accurate description of the tone patterns thought to exist in Proto SWM and seem to be a consequence of the break-down of a suprasegmental tone system of the type classified by McCawley [1967] as a partially-free tone-accent system. And since Proto SWM accurately conforms to Leben's five melody hypothesis, it provides a test for the suprasegmental claim. If Proto SWM is on its way to being a true (segmental) tone language, then the descendants of Proto SWM such Mende would be expected to continue this trend and fill the structural and formal gaps predicted by the suprasegmental theory. On the other, if Proto SWM is a suprasegmental tone language, then the constraints ought to hold, and we should expect new acquisitions by Mende to "fit" into existing categories. In the next section, evidence is presented to test this hypothesis.

From a historical point of view, the tone patterns of SWM appear to be the result of the breakdown of a two-toned partially-free pitchaccent system. Proto-SWM appears to be a language which could be described by a five melody suprasegmental phonology of the type envisioned by Leben for Mende. This raises the question: Is the fact that the tonal patterns of Proto-SWM can be characterized by the five tonal melodies a significant synchronic tonal fact, or is it a vestage of the diachronic development of this language? If this is a synchronic fact, then it ought to have some significance, that is, it ought to act as a constraint against new tonal patterns appearing in the language. Thus, one would expect if this constraint were true, that new forms would have to adjust their tonal patterns to meet the demands of the constraint in the same way that most borrowings conform to the structural conditions of a language. By this reasoning, accidental gaps would be filled, structural gaps would not be filled and formal gaps could not be filled without a total restructuring of the theory. Because Mende no longer reflects the limited tonal patterning of Proto-SWM, we must conclude either that conditions predicted by a suprasegmental theory of phonology did not exist in 
Proto-SWM, or that they did, but had very little effect on the future development of the language. At this time it is very difficult to understand the meaning of an extant, albeit ineffectual, constraint as being significantly different from a claim that no constraint exists.

7. Rule Evidence for the Melodic Hypothesis?

The melodic hypothesis has been offered as an explanation of the tonal patterns of modern Mende. As such, it has offered a tonal typology for the world's tonal languages: those which are segmental and those which are also suprasegmental, i.e. those which have a premapping component. If this scheme is designed only to account for the patterning of a language's tonal types, something which it does not do very convincingly for Mende, it has very little merit. If, on the other hand, this classification offers new insights into the nature of Mende tone beyond that already discussed and beyond that of a non-melodic hypothesis, the utility of the melodic hypothesis would be substantiated.

There are three areas in which the melodic hypothesis could make unique predictions concerning the tonal properties of Mende: first, if there is a rule which can best be stated at a pre-mapping level; second, if there is a rule at the post-mapping level but which requires the tonal patterns generated by the mapping rules; third, if there are diachronic processes which can best be stated using a premapping rule. In this section, the melodic hypothesis is examined with respect to each of these areas.

7.1. A premapping tone rule? A premapping tone rule, called "LOW SPREADING" by Leben [1973], was tentatively put forward and subsequently rejected because of its failure to accurately predict the facts. Consequently, as we shall see, the rule was demoted to a post-mapping rule.

The context in which the apparent melodic tone rule appears involves the common Western Mande phenomenon of polarization, mentioned in 6.4 above. Both the melodic and tension approaches agree that class 2 monosyllables are best analyzed having in the underlying segmental representation a short-rising tone, e.g. LH as in njă, with the melodic view making the additional claim that this segmental representation was derived from an 
underlying rising, LH tonal melody via the tonal mapping rules given in (la) and (lb). With respect to the underlying segmental representation (post mapping) of class 2 disyllables, however, these two views do not agree: the tension view proposing a L LH underlying segmental representation, e.g. pèlè 'path', and the melodic view claiming a L H segmental representation, e.g. pèlé 'path', following the mapping of a LH tonal melody on to the disyllabic morpheme.

Each of these segmental representations follow logically from within the context of their respective theoretical views with the key point of difference being the dirlering interpretations of the concept o distinctiveness [Chomsky and Halle, 1968]. The concept states that segments having identicai surface manifestations must have identical underlying representations. Thus, if two segments show the same surface tonal alternation, they must have the same underlying tonal representation.

From this stanapoint, the tension-based argument is clear. If the final syllable of class 2 monosyllables exhibits a specific tonal alternation and is analyzed as having an underlying short-rising tone, then the final syllable of class 2 disyllables which exhibits the same type of alternation must also have a short-rising tone. Thus the underlying representation of class 2 disyllables must be L LH.

The melodic viewpoint also uses the distinctiveness argument to support its position, claiming that distinctiveness can also apply to tonal patterns prior to their being assigned to specific segments. From this perspective, if both monosyllabic and disyllabic morphemes display the same tonal alternation then they must have the same underlying melody. Because monosyllables have a rising suprasegmental tonal melody, disyllables exhibiting the same tonal alternation must also have the same rising suprasegmental melody. Given this suprasegmental rising melody and the tonal mapoing rules ( $1 a$ ) and (lb) class 2 morphemes must have an underlying segmental tone pattern of $\mathrm{L} \mathrm{H}$. While it is possible to revise the suprasegmental mapping rules ( $\mathrm{la}$ ) and ( $\mathrm{lb}$ ) so that an underlying LH melody could be mapped onto a disyllabic morpheme to produce the same L LH segmentai pattern claimed by the tension view, this revision cannot be done without destroying the simplicity of the mapping system. 
Given these underlying representations, the task of the phonological rules is to eliminate the $\mathrm{H}$ of the $\mathrm{L} \mathrm{LH}$ melody when it is followed by another $H$ in the subsequent morpheme. Interestingly, Leben [1973] initially attempted to formulate this mule, called LOW SPREADING, but found that it would not work at this level. The argument runs as follows:

(23) LOW SPREADING

\begin{tabular}{|c|c|c|c|}
\hline e.g. & UNDER LY ING & ${ }^{\mathrm{L}} \mathrm{H}_{n \mathrm{nika}-{ }^{\mathrm{H}}} \mathrm{i}$ & $\mathrm{LH}_{\text {nika }}$ \\
\hline & LOW SPREAD & $\mathrm{L}_{\text {nika- }}{ }^{\mathrm{H}} \mathrm{i}$ & (not applicable) \\
\hline & MAPPING & nìkà-i & nìká \\
\hline & SURFACE & $n \grave{k} \varepsilon-i$ & nìká \\
\hline & Gloss & 'the cow' & 'a cow' \\
\hline
\end{tabular}

As a premapping rule, LOW SPREADING provides an explanation for the observation that polarization only occurs in morphemes with a surface $(L)_{1}^{n} H$ tonal pattern since this group of words all have an underlying LH melody and it is to this melody that LOW SPREADING applies.

However, as a premapping rule, LOW SPREADING makes an incorrect prediction about the tonal alternations of tri-syllabic morphemes which are claimed to have a LH melody. According to this prediction, such morphemes, e.g. ndèndélí 'shadow', ought to have a definite singular tonal pattern in which the high tone has been displaced two syllables, i.e. ndèndélí-í, as the following derivation illustrates:

\begin{tabular}{|c|c|c|c|}
\hline \multirow[t]{5}{*}{ (24) } & Underlying & & 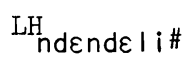 \\
\hline & LOW SPREADING & $\mathrm{L}_{\text {ndend }} \mid \mathrm{i}-\mathrm{H}$ & \\
\hline & MAPPING & ndèndè li-í & ndèndé। í\# \\
\hline & Predicted surface & *ndèndèlì-í & ndèndélî\#\# \\
\hline & Observed surface & ndżndélí-í & ndèndźl î\# \\
\hline
\end{tabular}

There is no evidence that a high tone is ever displaced more than one syllable in this context and in fact, no evidence that this rule can work at a premapping level, and consequently there is no evidence of a pre-mapping rule. 


\subsection{LOW SPREADING as a yost-mapping rule? Although LOW SPRE'ADING}

has been demoted to a post-mapping rule, if correct, it is still. supportive of the melodic hypothesis because it requires the toral patterns generated by the current mapping rules as injlit. Yet even at the post-mapping level, the LOW SPREADING rule is less explanatory, more complex and inaccurate. The rule is less explanatory for it fails to explain why only morphemes with a (L) $\mathrm{H}$ tone pattern undergo polarization. To show the relative complexity and inaccuracy, the LOW SPREADING must be contrasted with a competing analysis, one based on phonological tension.

\subsubsection{A tersion-based interpretation. The tension-based interpreta-} tion emphasizes the relationship between the number of distinct tones and the tone-bearing urits of the phonological string. In section 2, the number of possible underlying tonal patterns was claimed to be a function of principle (4) which stated that underlyingly, no more than two different tones may be associated with a single tone-bearing segment. The surface tone patterns and alternations can be shown to be the consequence of a parallel surface-level constraint:

(25) At the surface level, only one tone may be associated with a single tone-bearing unit. The only exception is utterance finally where a falling tone may remain.

The rules needed to derive this surface alternation function to resolve the contradiction between surface level and underlying constraints; that is, complex underlying tones have to undergo "tension releasing" processes.

In the case of the polarized tone, these processes are as follows:

(26) HIGH TONE ABSORPTION
$\hat{\mathrm{LH}} \rightarrow \mathrm{L} / \longrightarrow \mathrm{H}$
e.g. $\left.V_{m b-i}^{L H} \rightarrow\right|_{m b a-i} ^{I H}$

(27) LOW LOSS

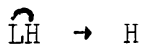

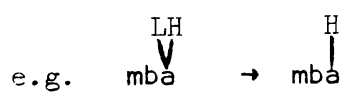


Interestingly, the falling tone undergoes a similar alternation and is subject to a parallel set of rules LOW TONE ABSORPTION and LOW LOSS:

(28) LOW TONE ABSORPTION<smiles>[13CH]CC=[13CH]</smiles>

(29) LOW LOSS

$\hat{\mathrm{HL}} \rightarrow \mathrm{H}$ (except finally) e.g. $\underset{\text { mbu-ngaa }}{\mathrm{H}} \bigwedge_{\text {mbu-ngaa }}^{L}$

e.g. $\underset{m b u-i}{H L} i^{\prime H} \rightarrow L^{H} !^{\prime H}$

The parallel nature of these two sets of rules suggests a broader generalization: that these rules can be integrated to produce a simpler rule set and a neater generalization. These rules are ALPHA TONE ABSORPTION and SIMPLIFICATION:

(30) ALPHA TONE ABSORPTION

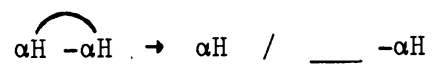

(31) SIMPLIFICATION

$$
\mathrm{L} \rightarrow \phi /\left\{\frac{\mathrm{H}}{\mathrm{H}} \text { except finally }\right\}
$$

7.2.2. A comparison of the two analyses. The two analyses differ with respect to only one rule. This difference stems from a difference in the underlying representation of class 2 disyllabic words. It will be recalled that class 2 disyllabic morphemes are represented as cìcv́ by the melodic analysis and as cìc $\bar{v}$ by the tension analysis hypothesis. These differences of representation necessitate different rules. The alternation of class 2 disyllables cannot be handled by HIGH TONE ABSORPTION since the final syllable does not contain a complex tone. Consequently a new rule, LOW TONE SPREADING is required: 
(32) LOW SPREADING

$\mathrm{H} \rightarrow \mathrm{L} / \mathrm{L}$ $\# \mathrm{H}$

Each of these rules produces a slightly different set of derivations, given in (33):

(33) Based on the Melodic Hypothesis

$\begin{array}{lllll}\text { a. underlying } \\ \begin{array}{l}\text { LOW SPREADING } \\ \text { SIMPLIFICATION }\end{array} & \begin{array}{l}\text { mbà-íl } \\ \text { surface }\end{array} & \text { mbă\# } & \begin{array}{l}\text { pèlé-í } \\ \text { pèlè-í }\end{array} & \text { pèlé\# } \\ \text { gloss } & \text { 'the rice' 'rice' } & \text { 'the path' 'path' }\end{array}$

b. Based on the Non-melodic Hypothesis

\begin{tabular}{|c|c|c|c|c|}
\hline underlying & mbă-i & mbǎ\# & pèlě-í & pèlě\#\# \\
\hline ABSORPTION & mbà-í & & pèlè-í & \\
\hline SIMPLIFICATION & & mbǎ\# & & pèlé\# \\
\hline surface & $m b \grave{\varepsilon}-\hat{i}$ & mbá\# & pèlè-í & pèlé\# \\
\hline gloss & 'the rice' & 'rice' & 'the path' & 'path' \\
\hline
\end{tabular}

7.2.3. Criticisms of LOW SPREADING. While LOW SPREADING is a possible rule for either system, it is more complex from the perspective of the tension model. For to choose LOW SPREADING over HIGH TONE ABSORPTION 
means, first, selecting a rule which does not conform to the surface constraint and second, to breaking the symmetry of the ALPHA TONE ABSORPTION rule. Thus, the selection of the optimal rule is a choice dependent upon the form of the underlying representation of disyllabic class 2 words which, as we have seen, is in turn a consequence of the underlying assumptions about the nature of Mende tone. Inversely, the empirical adequacy of each rule is therefore a reflection of the adequacy of the supporting hypothesis. In this regard, LOW SPREADING has some serious difficulties which further detract from the potential value of the melodic hypothesis.

First, the melodic hypothesis makes wrong predictions. As the rule is now formulated, it predicts that some trisyllabic morphemes ought to undergo a tonal alternation:

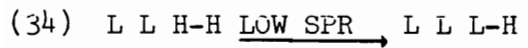

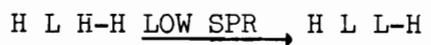

While morphemes of this type have been shown to exist in Mende (section 3) these morphemes do not alternate as predicted by the melodic hypothesis. While the lack of alternation on these forms can be explained by a ruleblocking diacritic, such an ad hoc explanation competes poorly with that of the tension analysis which does not predict these aberrant alternations in the first place. Since these tonal patterns do not represent complex tones, the tension hypothesis does not predict a tonal alternation. Secondly, the LOW SPREADING rule fails to provide an explanation as to why disyllabic morphemes with an underlying $\mathrm{L} H$ tone pattern do not alternate. In addition to the disyllabic morphemes which display tonal polarization Mende (class 2) also has another set of disyllabic morphemes with a L H tonal pattern (class 6) which do not display tonal polarization.

Both analyses agree that the underlying tonal representation of class 6 morphemes must be $L \mathrm{H}$. This representation causes no difficulties for the tension-based analysis because class 2 and class 6 are 
phonemically distinct ( $\mathrm{L} \mathrm{LH}$ and $\mathrm{L} H$ respectively). However, the melodic hypothesis does not represent these two types of morphemes as tonally distinct and consequently is forced to distinguish between these two tonal alternations using a diacritic feature. Because class 6 is numerically smaller than class 2, Leben [1973] has suggested that class 6 morphemes be marked with the diacritic feature.

Customarily diacritic features have been used to distinguish one class of morphemes from another which would otherwise have the same underlying representation but which display different surface realizations. The use of such diacritic features marks an "unnatural" period of development of a language such as borrowing. Thus the use of a diacritic feature in this case would suggest something such as the following: that all class 6 morphemes are borrowed while all class 2 morphemes are not. While the evidence does show that all class 6 morphemes appear to be recent acquisitions, many class 2 morphemes also appear to be recent borrowings. This being so, the meaning of this diacritic feature is unclear.

One of the indicators of a recent borrowing in Mende is the initial consonant. The comparative evidence, given in Dwyer [1974], shows that recent Mende borrowings begin with one of the following consonants: $b$, $d, g, g b, v, s$, while native Mende morphemes do not. The fact that class 2 morphemes can be found which begin with one of the above consonants, as given in (35) below, indicates that tone class 2 includes recent borrowings and consequently that the proposed diacritic feature does not distinguish native words from borrowings.

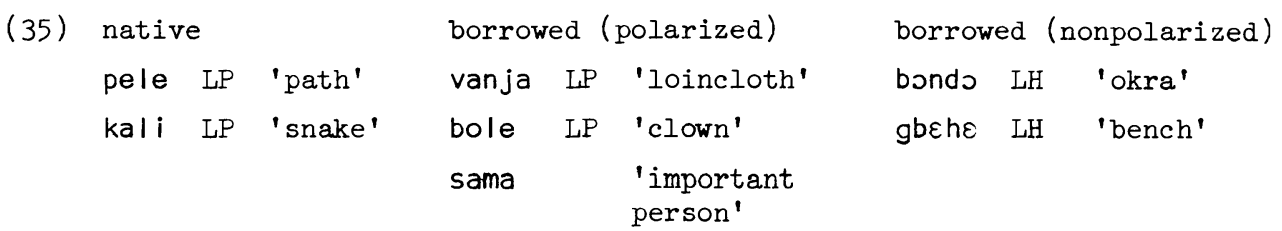

And while an explanation other than borrowing might be found to explain the use of the proposed diacritic feature, no such explanation has been offered nor appears likely. But the diacritic feature analysis also suffers from a second major difficulty. Unlike natural segmental features, diacritic 
features are suprasegmental (morpheme level) features which are mapped onto each segment in the morpheme. The intent behind this chomsky and Halle [1968] formalism was not only to distinguish diacritic features from natural features, but to make it possible to generalize about a series of otherwise unrelatable events. For example, borrowings frequently fail to undergo a series of unrelated rules or frequently display a special set of word-forming properties. These facts which are ungeneralizable using natural segmental features can be shown to be related through the use of a single diacritic feature. Thus, one of the ways of arguing in support of the use of a particular diacritic feature is to show that its use relates at least two independent facts.

The diacritic feature proposed for Mende to distinguish class 2 and class 6 morphemes has the weakness that it does not relate any such facts, its usage is in the strictest sense of the term "ad hoc" for it only marks the exceptionality of type 6 morphemes with respect to the polarization mule (LOW SPREADING). Many of the morphemes identified as borrowings on the basis of their initial consonant or their membership in tone class 6 (see above) are not exceptions to the other phonological rules in Mende such as FRONTING, CONSONANT MUTATION, and HIGH TONE COPYING (these rules are discussed in detail in Dwyer [1973]). In each of these cases, the question of whether a borrowing undergoes a rule or not can be answered by referring to the specific rule's structural description. Thus no independent evidence can be found to support the existence of the proposed diacritic.

7.2.4. Criticisms of the tension analysis. Despite what appear to be clear advantages of the tension analysis it has been subject to criticism, however. Part of Leben's reason for choosing a suprasegmental analysis instead of a tension based (rising-tone) analysis of polarization was due to four apparent weaknesses which he found in the segmental analysis which are summarized below (from Leben [1973:63]).

(36) i. This argument ignored the fact that although regular phonological features were being employed ... they were being employed diacritically, in the sense of Kiparsky [1968].

ii. That the distinction is used solely to permit the grammar to 
predict which nouns would and which nouns would not undergo tone deletion (i.e. ABSORPTION).

iii. This analysis had no account of the fact that words like navo (LH) are extremely rare, while words like nika (LP) are common.

iv. Finally, the analysis failed to observe that the abstract rising sequences posited for nouns like nika were always preceded in the same word by an $L$ on the first syllable.

If the tension analysis is correct, it ought to be able to provide answers to each of the criticisms raised against it.

Absolute neutralization is not to be confused with abstractness, a similar but quite distinct phenomenon. Whereas the principle of absolute neutralization argues against using a phonological feature for diacritic purposes, it does not claim that an underlying representation of a phoneme must be one of the observed surface level allophones. In this regard, the melodic hypothesis admits to an abstract representation of type 2 monosyllables for the underlying short-rising tone which appears on the surface as either a low tone or a high tone, but never a rising tone. Thus the issue is not that of abstractness but rather that of absolute neutralization. Furthermore, the use of an underlying shortrising tone as part of monosyllabic or disyllabic morphemes does not violate Kiparsky's condition of absolute neutralization. Kiparsky introduced the condition to prevent the use of phonological features to set up "underlying distinctions for the sole purpose of classifying segments which do and those which do not meet the structural analysis of a rule" [Kiparsky, 1968:9]. Kiparsky gives the following example:

$$
\begin{aligned}
& \mathrm{A} \rightarrow \mathrm{B} / \mathrm{C} \\
& \mathrm{D} \rightarrow \mathrm{C} \text { (everywhere) }
\end{aligned}
$$

Kiparsky referred to a rule such as $D \rightarrow C$ as a case of "absolute neutralization". His claim was that by eliminating absolute neutralization, it would be possible to eliminate the diacritic use of phonological features. Kiparsky by no means implied that the use of phonological features should not be used to describe what he called "contextual neutralization", for this is the kind of neutralization which results in what is often called morphophonemic alternation. He cites several examples of contextual neutralization including the classic English write writer, 
and the German bunt bunde as examples warranting phonological rather than diacritic analyses.

To contrast the tension analysis proposed above, which does not make a diacritic use of a phonological feature, the following analysis, which does, is offered:

(38) 1. Polarized tones are high tones that appear on voiceless vowels, e.g. nikA, nonpolarized tones are high tones that appear on voiced vowels, e.g. bj̀ndó .

2. Low spreading applies only to high tones on voiceless vowels.

3. After, which, all voiceless vowels become voiced.

The objection raised in (36ii), which questioned the lack of independent motivation for the rising tones, is also wrong, for the motivation of the underlying rising tone was well established for monosyllables [Dwyer, 1971], a conclusion which both the melodic and tension-based analyses agree with.

And, as was argued above (7.2) on the basis of the segmental viewpoint and the concept of distinctiveness, that the postulation of a shortrising tone on the second syllable of class 2 morphemes follows directly from the conclusion that the final syllable of monosyllables having a short-rising tone exhibits the same tonal alternation.

The third criticism (36iii) argues that the grammar provides no account of the fact that morphemes of the type binds are extremely rare in Mende, even though they are segmentally simpler. While it is true that the tension-based analysis does not provide a synchronic explanation of this fact, it claims that this observation is not relevant to a synchronic grammar. It was shown in (13) that class 6 words (bj̀ndó, nàvó) all appear to be relatively recent borrowings, but it is not clear that this historical information could be gathered by a native speaker of Mende from the synchronic data at hand. And if it cannot, then how can this kind of information be included in a synchronic grammar of Mende?

The fourth claim (36iv) that ABSORPTION analysis fails to explain why polarized tones are always preceded by low tones is correct. It is also true, as pointed out above, that the melodic hypothesis cannot explain this fact either. However, as argued above, this fact is of historical relevance only and would not be considered to be synchronically meaningful to a Mende speaker. 
Although the segmental synchronic analysis would not attempt to include the kind of information raised in (36iii) and (36iv), its diachronic counterpart would predict that on the basis of simplicity, more class 6 morphemes $\mathrm{I} \mathrm{H}$ will be acquired through borrowing in the future than morphemes of the type L LH, thereby increasing the ratio of $\mathrm{L} \mathrm{H}$ morphemes to $\mathrm{L} \mathrm{LH}$ in the language. It would also predict that more morphemes like kpúkpùa will be acquired and that the apparent constraint against high tones preceding a polarized tone will be lost.

7.3. Premapping diachronic rules? A third prediction that the melodic hypothesis could make concerns the types of possible diachronic tone changes. Since the specific tonal patterns of a language are determined by the types of possible underlying tonal melodies and mapping rules, then some types of diachronic tonal developments ought to be characterizable in terms of these elements. For example, were a melody to restructure, then the surface tonal patterns of monosyllabic, disyllabic, trisyllabic morphemes which have this melody would be affected. Alternatively, if a given mapping rule were altered, then the location of the existing tonal "notes" would be likewise altered.

Importantly, however, the noted diachronic Southwestern Mande tonal changes do not reflect any melodic principles at work, rather they reflect events that are better understood using a tension-based model. Two such diachronic developments in SWM will serve to illustrate this point. The first is the restructuring of class 4 tonal patterns in Mende and the second is the restructuring of class 3 and class 4 tonal patterns in Bandi.

These developments can be detected by examining the tonal correspondences given in (16) of section 6.1 .

7.3.1. Mende class 4 restructuring. The development of $\mathrm{H} H L$ to $\mathrm{HL}$ in Mende (see Dwyer [1977] for details) cannot be characterized as a change in melody, for in this development, the melody remains the same. Therefore, the development would have to be characterized as a change in mapping rules. However, to change the mapping rule to produce the right tonal patterns on class 4 morphemes would inadvertently produce the wrong tonal pattern on the remaining tone classes (unless of course two 
different sets of mapping rules are used, a move which undermines the original simplicity of the melodic hypothesis).

As pointed out in Dwyer (1977), this development when viewed from the perspective of a tension-based hypothesis can be seen as a variety of ABSORPTION rule, one in which the tones are preserved, but the tension in the morpheme is reduced.

7.3.2. Bandi tonal class restructuring. A second Southwestern Mande tonal development involves the restructuring of Bandi morpheme-final falling tones to simple high tones. This development affected tonal classes 3 and 4 as is shown in the following comparison of Bandi and Loko (39) (Loko being used to represent the earlier state of Bandi before the tonal restructuring).

$\begin{array}{llll}\text { Class } & \text { Loko } & \text { Bandi } & \text { Gloss } \\ 1 & \text { ngúlú } & \text { ngúlú } & \text { (no change) } \\ 2 & \text { nikǎ } & \text { nìkǎ } & \text { (no change) } \\ 3 & \text { ngètê } & \text { ngèté } & \text { 'pestle' } \\ 4 & \text { kálî } & \text { kálí } & \text { 'hoe' } \\ 5 & \text { bj̀lò } & \text { bذ̀lò } & \text { 'trousers' (no change) }\end{array}$

Since this change involves the loss of a note, it cannot be characterized as a change in mapping mules and it must be seen as change in melody. Importantly, from a melodic standpoint, this development affects only those LHL morphemes which are of one and two syllables in length only. Morphemes of three syllables or more in length with a LHL pattern remain unaffected. This diachronic development cannot be stated using premapping tone values.

From the perspective of the tension-based hypothesis, this change is a perfectly natural development, following along the same lines as SIMPLIFICATION (31). What appears to be happening here is that the surface-level constraint (25) is becoming an underlying constraint.

Thus, an examination of two diachronic tonal developments in Southwestern Mande has revealed events which at best are only awkwardly described by a melodic hypothesis and which are easily understood given a tensionbased perspective. Again then the melodic hypothesis has failed to reveal any new insightful comments about the nature and development of Mende tone, 
and the tension-based analysis has shown these developments to be within its range of prediction.

7.3.3. More support for the short-rising analysis. Interestingly, when classes 3 and 4 restructured, the surface patterns class 4 ( $\mathrm{H} \mathrm{HL}>\mathrm{H} H$ ) became tonally indistinguishable from class 1, reflecting the fact that these two tonal classes have merged and have developed the same underlying tonal representations. When class 3 restructured ( $\mathrm{L} H \mathrm{HL} \mathrm{L} \mathrm{H}$ ) it did not merge with tone class 2 .

If class 2 disyllabic morphemes are represented as $L \mathrm{H}$, e.g. niká 'cow', as proposed by the melodic analysis, then the simplification of class 3 disyllabic morphemes to $\mathrm{L} \mathrm{H}$, e.g. ngèté 'pestle', ought to result in a merger of these two classes. If on the other hand, class 2 disyllabic morphemes are represented as $\mathrm{L} L \mathrm{LH}$ as proposed by the tension-based analysis, then the simplification of class 3 disyllabic morphemes ought not to result in a merger of these two classes. The fact that these two classes do not merge supports the low-rising analysis of the tension-based analysis. The non-distinctness of Bandi classes 1 and 4 and the distinctness of classes 2 and 3 are shown in (40):

$\begin{array}{lllll}\text { class } 1 & \text { class } 2 & \text { class } 3 & \text { class } 4 & \\ \text { ndàmbá-ngí } & \text { nikà-í } & \text { nyàhà-í } & \text { ngìlá-í } & \text { noun + 'the' } \\ \text { ndàmbá+nínâ } & \text { nikà+nìnâ } & \text { nyàhà+nínâ } & \text { ngìlá+nínâ } & \text { noun + 'new' } \\ \text { 'crocodile' } & \text { 'cow' } & \text { 'woman' } & \text { 'dog' } & \end{array}$

8. Conclusion: What Sort of a Tone Language is Mende?

The conclusion of this paper is clear: Mende is not a melodic tone language of the type envisioned by Leben [1973]. The original claim that Mende tonal patterns could be explained by positing just five underlying tonal melodies and a mapping rule were shown to be inadequate because of a significant number of counterexamples. Furthermore, the melodic claim was examined further to see if there were other types of generalizations that could be made at the premapping 
level or which required the tonal patterns generated by the proposed tonal melodies and mapping rules. The evidence, both synchronic and diachronic, again demonstrated the inutility of the melodic hypothesis.

If Mende is not a melodic tone language then the question remains, "What sort of tone language is it?" In answer to this question a tension-based hypothesis was advanced which claimed that the tonal phenomena of Mende could only be understood by reference to the relationship between tonal and segmental units, specifically the number of permissable tonal units assignable to a given tone-bearing segment. In both the case of Mende tonal patterns and Mende tonal processes, both synchronic and diachronic, this tension-based model provided a principled interpretation as to why Mende functions tonally the way it does and thereby answers the question raised in this paper.

REFERENCES

Chomsky, N., and M. Halle. 1968. The Sound Pattern of English. New York: Harper and Row.

Dwyer, D. 1971. "Mende tone." Studies in African Linguistics 2:117-30.

Dwyer, D. 1973. "The comparative tonology of Southwestern Mande nominals," Doctoral dissertation, Michigan State University.

Dwyer, D. 1974. "The historical development of Southwestern Mande consonants." Studies in African Linguistics 5:59-94.

Dwyer, D. 1978. "Idiosyncratic, suprasegmental processes in Mende." Studies in African Linguistics (forthcoming).

Goldsmith, J. 1975. "Tone melodies and the autosegment." In Robert K. Herbert (ed.), Proceedings of the Sixth Conference on African Linguistics, pp. 135-47. Working Papers in Linguistics, no. 20. Columbus: The Uhio State University Department of Linguistics.

Goldsmith, J. 1976. "An overview of autosegmental phonology." Linguistic Analysis 2:23--68.

Houis, M. 1963. Études déscriptive de la langue Susu. Dakar, Memoires de L'IFAN, No. 67.

Hyman, L., and R. Schuh. 1974. "Universals of tone rules: evidence from West Africa." Linguistic Inquiry 5:81-115.

Innes, G. 1969. A Mende-English Dictionary. Cambridge: The University Press. 
Kiparsky, P. 1968. "How abstract is phonology?" Bloomington: Indiana University Linguistics Club.

Leben, W. 1973. "Suprasegmental phonology." Doctoral dissertation, Massachusetts Institute of Technology.

McCawley, J. 1964. "What is a tone language?" Paper presented at the summer meeting of the Linguistic Society of America.

Spears, R. 1967. Basic Course in Mende. Evanston: Northwestern University Press.

Welmers, Wm. 1961. "Internal evidence of borrowing in Kpelle." General Linguistics $4: 1-9$.

Welmers, Wm. 1975. "Historical implications of the Vai consonant system." In Robert K. Herbert (ed.), Proceedings of the Sixth Conference on African Linguistics, pp. 124-84. Working Papers in Linguistics, no. 19. Columbus: The Onio state University Department of Linguistics. 
PAPERS FROM THE EIGHTH CONFERENCE ON AFRICAN LINGUISTICS

University of California, Los Angeles, April 1-3, 1977

The following papers were presented in the Language Planning Working Group at the 8th Conference on African Linguistics. 



\author{
Rachel Angogo \\ University of Texas at Austin
}

\title{
1. Introduction
}

In June 1976 a protest of African school children from SOWETO, a Johannesburg township, triggered a series of bloody riots that spread to several other South African cities. The children were protesting a government decision to replace English with Afrikaans as the medium of instruction for certain subjects in African secondary schools. Although the language issue did anger the students, the underlying cause of the riots was the racial policy of the white minority government, a policy in which language has played a crucial role.

\section{Cultural and Lingistic Situation}

South Africa is a multi-cultural society, and to properly understand the linguistic situation, it is best to first look at the peoples that constitute that society and what part each plays in the present social system.

South Africa has a population of about 21 million people, of whom $83 \%$ are non-white. The following is a breakdown of the population by race: African, $70 \%$; White, $17 \%$; Coloured ${ }^{1}, 10 \%$; Asian ${ }^{2}, 3 \%$.

The two official languages of South African are English and Afrikaans. Afrikaans is a Dutch-based language that developed among the whites of Dutch descent (called Afrikaaners) and the coloureds. It has borrowed from both African and Malaysian languages. An understanding of the importance of this language to the Afrikaaner in his striving for political power and cultural recognition is essential if one is to comprehend the present situation in South Africa.

"Coloured" is a term used in South Africa to describe those of mixed blood, particularly between Whites and Hottentots.

2 The Asian population is mainly Indian, the descendants of workers brought to South Africa in the $1800^{\prime}$ 's to harvest sugar cane. 
About $53 \%$ of the white population speaks Afrikaans as a first language. English is the mother language of 37\%. The remaining whites speak Greek, Portuguese, German, etc. as first languages. Less than 2\% of the whites come from homes in which both official languages are used, a figure which serves as a good indication of the strictly limited relationship between the two white communities.

The linguistic situation among the non-whites is more complex. The mother tongue of $90 \%$ of the coloured South Africans is Afrikaans. As a first language, more than $80 \%$ of the Asian population speak Indian languages, the most prominent ones being Tamil, Hindi, Gujarati and Urdu.

Most Africans speak Bantu languages as their mother tongues, and these languages can be divided into two main groups: Nguni and Sotho. About $60 \%$ speak $\mathrm{Nguni}$ languages while speakers of Sotho languages number $35 \%$. The following is a list of the languages that make up each group:

1)

$\begin{array}{ll}\text { NGUNI } & \text { SOTHO } \\ \text { Zulu } & \text { Tswana } \\ \text { Xhosa } & \text { Pedi } \\ \text { Swazi } & \text { Southern Sotho } \\ \text { Ndebele } & \end{array}$

Although the two language groups are structurally related, they are not mutually intelligible. No such problem exists, however, within each group. A Zulu speaker has no trouble understanding a Swazi speaker, and a Tswana speaker can easily understand a speaker of Pedi or Southern Sotho.

\section{Historical Sketch of South Africa}

The Bantu people were living in what is now South Africa when the first Dutch and French Huguenot settlers arrived in the 1600's. These settlers came to South Africa at a time of religious oppression in Europe, and they left their motherland to escape from such oppression. The nature of their first constitution, which is indeed a democratic constitution, clearly indicates their purpose. In those early years, the Africans and the settlers lived peacefully together. However, this peace was eventually shattered as the population grew and demand for land increased.

The British first arrived in the late $1700^{\prime} \mathrm{s}$ and from the very beginning, they were at odds with the Afrikaaners, whom they found there. There followed a long series of wars that ended in the 1870's with the white settlers' final subjugation of the Africans. The English-Afrikaaner conflict, however, steadily increased. In the early 1900's a war broke out between the two groups, largely because of British interest in discoveries of gold and diamonds. Britain achieved a pseudo-victory in this war and shortly afterwards, the two groups united the British and Afrikaaner colonies and declared their independence. 
The basically rural South African society changed rapidly after the discovery of gold and diamonds in the last quarter of the nineteenth century. These discoveries and the rapid industrialization that they triggered created a great need for unskilled labour, a need that could easily be filled by the vast number of African labourers. To get Africans into the labour force, the government passed a number of bills such as the hut tax. To obtain money to pay such taxes, Africans sought work in gold and diamond mines and in the cities that sprang up around them.

\section{Group Conflicts}

As already noted, Afrikaaners have been at odds with the English since the latter arrived in South Africa. This feeling of resentment is still an important factor in South African society. Besides opposing what they regarded as "British imperialism," Afrikaaners have felt the pressure of the Africans, who greatly outnumber them. As a reaction to such insecurity and as a defense of the Afrikaaner culture, (one that had developed its own distinctive social structures, religious institutions and language), a strong Afrikaaner nationalism developed. This nationalism has centered around the recognition of Afrikaans as a national language of equal status with English.

The English-Afrikaaner language debate began in earnest at the time independence was granted in 1910. When representatives met to draw up the constitution, the Afrikaaners were successful in getting Afrikaans named as an official language. In the 1920's numerous political and cultural organizations sprang up whose main purpose was the promotion of the Afrikaans language and culture. ${ }^{3}$ The creation of these organizations reflected the surge of Afrikaaner nationalism, a nationalism whose cornerstone was the Afrikaans language. Although the Afrikaans-speaking whites far outnumber the English-speakers, the Afrikaaners did not get control of the government until 1948, a date that marks a turning point for South Africa. From that time, the segregation and racial discrimination which has always been present in South Africa in various forms, became official government policy known primarily under the name of separate development, or "apartheid".

\section{Apartheid}

The Afrikaaner political party (National Party) came to power in 1948 with a promise to strengthen and safeguard the white supremacy that had been built up over 300 years of white settlement. Apartheid, the policy devised to maintain that supremacy, is described in the 1947 election Manifesto of the National Party as follows:

${ }^{3}$ One of these organizations, the South African Bureau of Racial Affairs (SABRA), is responsible for developing the principle of separate development. 
In general terms our policy envisages segregating the most important ethnic groups and subgroups in their own areas where every group will be able to develop into a self-sufficient unit. We endorse the general principle of territorial segregation of Bantu and whites...the Bantu in urban areas (white areas--BR) should be regarded as migratory citizens not entitled to political or social rights equal to those of the whites... The process of detribalization should be arrested."

In keeping with the policy, South Africa has been divided into white and African areas. The whites who make up $17 \%$ of the population have control of $85 \%$ of the land, while the African majority are left the remaining $15 \%$. To promote the government's policy of retribalization, whose purpose is to counteract the unifying effects of urbanization, the African area has been further subdivided into eight homelands--often called Bantustans --one for each group within the African population: Zulu, Xhosa, Tswana, etc.

All Africans are citizens of their homeland regardless of their place of birth or residence. A Zulu, born and raised in Johannesburg, is a citizen of the Zulu homeland, even though he may never have set foot in it. Citizens of the homeland are not guaranteed any benefits or rights outside their homeland.

In establishing the homelands, the government has consolidated and reconstructed mono-ethnic areas with a political structure modeled on traditional chieftainship. The homeland governments have been set up over the last 10 years in a step-by-step fashion. They have been granted rights to control taxation, education, agriculture, and public works within the homeland. All other powers remain in the hands of the white government, so that the most a homeland can attain is a quasi-independence.

The Asian and coloured peoples have not been given homelands, and the government has made no plans for such homelands in the future. These two groups constitute such a small percentage of the population that they pose no serious threat to the system.

\section{The Role of Language in Apartheid}

Keeping in mind the fact that Afrikaaner nationalism was based in considerable measure on resistance to British culture and language, and on concern for the rapidly growing African masses, we can now examine how language policies fit into the program of apartheid.

6.1 Education. The South African educational system is organized in the following way: 7 years of primary education, 3 years of junior secondary and 2 years of senior secondary. As in the British system, to move from one level to another, a child must pass a comprehensive exam. 
Africans, Asians, coloureds and whites are all educated as independent groups within the population, a separateness emphasized by differences in financing, differences in syllabus, and differences in levels of achievement deliberately related to different employment needs. For example, the priorities in the government's Bantu education programme are placed on mass literacy and widespread primary education, priorities which prepare the majority of Africans for a future as unskilled workers.

There is a separate government agency to administer each educational system, but they are essentially controlled by whites. The national government claims that each homeland will have control of its own education. Just how complete this control is can be questioned. At the present time in South Africa, Bantu education is controlled by two bodies: the homeland governments control it within the homelands and the ministry of Bantu education controls it within the urban and white areas, where so many Africans live as labourers.

Prior to the Afrikaaner rise to power, an African child received the first 4 years of primary instruction in his mother tongue. Both official languages were introduced as a medium of instruction. By the end of primary school, all instruction, with the exception of religious and Bantu language studies, was in this official language. As the Afrikaaners introduced their concept of separate development, things changed. Mothertongue instruction was continued throughout the 7 years of primary education. Instruction in one of the official languages did not begin until secondary school level, although both English and Afrikaans were studied as subjects throughout the primary school. In the light of the aims of apartheid, the motivation benind this change would seem to indicate an attempt to isolate each language group from each other and from the rest of Africa and the world at large. The common consciousness that had developed among the Africans as a result of urbanization and industrialization would then be diminished, leaving room for divisions, based on tribal feelings.

During the years of change, the government launched a program to adapt and update the Bantu languages for use in the educational system. Comprehensive lists of 8,000 words were prepared in each language and placed at the disposal. of teachers. About $70 \%$ of the words on the word list already existed in the languages and the remainder were created by 'bantuizing' English or Afrikaans words. Also the government encouraged African writers to publish textbooks in their own languages.

For the most part Africans were against the change, but were powerless to do anything about it. Often it meant that children, especially those of minor language groups, had to travel great distances to attend a school that taught their own language or a language near enough to their own. Also many Africans felt that such a separation fostered mistrust. Among the outspoken critics of this policy have been African authors, who feel a need to communicate to an audience larger than their tribe, 
and it is only through English that they can do this. It is in their interest, therefore, to have as many people literate in English as possible. Since most African children don't get past primary school, proficiency in English must be started at an early age.

As the homeland governments were given partial control of education, most of them went back to the old policy of beginning instruction in an official language at primary school. In today's South Africa, therefore, there are two policies on mother-tongue instruction, one in the homelands and one in the white areas.

In the homelands, the mother tongue is used for the first three or four years. Both official languages are introduced as subjects in the first year. After the fourth year, English becomes the medium of instruction. English has been chosen for two reasons: (1) many Africans consider Afrikaans the language of the oppressor, and, (2) because of its international status, English gives Africans a bond with other parts of Africa and the rest of the world. Consequently, in the homelands English remains the medium of instruction throughout secondary school, with a Bantu language and Afrikaans being taught as subjects. In white areas however, the official government policy states that half of the instruction should be in Afrikaans and half in English.

The riots in SOWETO, Johannesburg, started when the government tried to enforce instruction in Afrikaans in certain subjects. The students rejected this change, and riots broke out. After bloody riots involving the death of many school children, as well as a number of other Africans, the govermment backed down. That was one of the first times involving a crucial issue that the South African government has bowed to African demands. Why did the government back down if they were convinced that Afrikaans was the right language for the Africans? Was it an admission that what they were doing was wrong? Or was it the result of pressure from the outside world? The government's reaction should be regarded as important because, if the regime realized its mistake, then the time is ripe for a revision of the entire language policy in South Africa.

Language in the coloured schools is not so much an issue. More than 90\% of the coloured speak Afrikaans, and this is the language used in primary and secondary school levels as a medium of instruction. English is taught as a subject in primary school.

Although only 20\% of the Asians speak either English or Afrikaans as a first language, one of these languages is used as a medium of instruction at both levels. Which language depends upon the area in which the child lives. If he lives in an Afrikaans-speaking area, it will be Afrikaans, and vice versa, for English.

The government policy of cultural isolation applies even within the white population. Afrikaaner children attend Afrikaans schools, and English children attend English schools. The other official language is introduced after primary school in some schools. 
Until the mid-50's the non-whites who qualified could attend white universities. Now there is a separate university system for each racial group. The coloured and the Asian each have a separate university; there are three African universities. All instruction in these universities is done in one of the official languages. For the whites there are eleven universities: 6 English-speaking and 5 Afrikaans-speaking.

The policy of separate development has effectively divided children and isolated them in mono-lingual schools during the most impressionable years of their lives. Language and cultural differences have been stressed, and the opportunities for young people to associate with and learn to understand children of other cultures have been diminished. To the Africans, it has caused a decline in competence in the school subjects.

6.2 Media. There are about 21 daily newspapers in South Africa, 16 published in English, and 5 in Afrikaans. There are numerous African papers, most of them published in English. A few attempts to publish in African languages have been made, but usually they are not successful. Either the paper dies a natural death due to lack of funds, or it fails to attract enough readers because of a high rate of limited literacy.

Until early 1976, South Africa had no television service. Radio was, and indeed still is, the most important means of communication. T.V. has 37 hours a week, half in English and half in Afrikaans. Radio service throughout South Africa is controlled by the government under the auspices of South African Broadcasting Corporation. There is broadcasting in 9 languages: English, Afrikaans, and 7 Bantu languages.

6.3 Mining. Mining is the most important sector of South Africa's economy. The gold and diamond mines employ workers from all parts of South Africa and from neighboring countries like Malawi, Swaziland, Rhodesia, Botswana and Mozambique. Most of the labourers speak languages that are for the most part not mutually intelligible and very few of them speak English or Afrikaans. Communication in the mines has therefore been a problem.

A pidgin called Fanagalo has developed as a solution to this problem. It is a simplified form of a Bantu structure that has vocabulary, limited largely to terms relevant to miners' work. The language can be learned in a short time. Before a new recruit is sent into the mines, his first orientation includes learning Fanagalo.

Contact due to urbanization has resulted in the formation of a contact language called Tsotsi. Originally, it was a jargon of criminals (in Sotho, tsotsi means criminal), but now it has grown to the status of a pidgin. A lot of the vocabulary is from Sotho, but it has also borrowed heavily from the Nguni languages and Afrikaans. 


\section{7. $\underline{\text { Creole }}$}

In the struggle for recognition of their language, many Afrikaaners have transferred their ideal of racial purity to the purity of their mother tongue and its history. As a result, a number of Afrikaaners advocate keeping their language free from the corrupting influence of foreign words, especially English words. In treating the history of the language, advocates of the purity movement have insisted that Afrikaans developed directly from Dutch and is singularly free from the taint of foreign influence. In doing so, Afrikaans linguists have rejected the idea that Afrikaans developed through a creolization of Dutch spoken by the early 17th century settlers. This creolization was the result of the mixing of several different peoples and languages: Dutch, Malaysian (or a Malayo-Portuguese Creole), and African languages. Those Afrikaans scholars who want to see their language as being as pure as their race, quite naturally reject any concept of creolization.

Afrikaaner linguists tend to confine the study of their language to the usage of the whites. In historical studies, only when a linguistic phenomenon occurs among whites is it regarded as being a legitimate part of the language.

\section{Multi-lingualism}

Many Afrikaaners speak English, but not vice versa. English has long been a language of commerce and international contact, while Afrikaans has mainly been associated with rural life. To be successful elsewhere then, it has always been necessary for the Afrikaaner to know English. Many Afrikaaner farmers are able to speak African languages through contact with farm labourers, and a few other whites claim knowledge of African languages.

However, for the Africans, multilingualism is a necessity for survival. Most civil servants and police are Afrikaaners, and when dealing with Africans, they insist on being addressed in Afrikaans. Since there are countless laws and regulations that affect Africans in white areas, an African must constantly deal with those officials. For better or worse, those Africans working in white areas, try to know some Afrikaans. But to be able to succeed economically, an African must generally be able to speak some English, the language used in commerce. Urban Africans are also usually proficient in at least one other Bantu language.

To some extent, Asians find themselves in conditions similar to those of Africans. They must speak Afrikaans in order to deal with the white officials, and English in order to exist economically.

\section{South Africa in the Context of Africa}

The language problems in South Africa are not peculiar to that part of the world. Before independence, certain other parts of Africa had similar problems. From observation of independent Africa, we can draw certain generalizations. 
Even in the presence of one trans-tribal language, an African language that is tribally neutral, it has been the case that a foreign language was chosen by Africans as one of the weapons to conquer internal strife and to encounter the colonizer. The foreign language in Africa has always been a language of a small elite, and it is from this elite that African leadership has come. The presence of a foreign language has served to unify the people, at least temporarily. A common war is fought, and independence is achieved. Then the language questions arise anew. The turn of events now brings about the question of a national language. The intense desire for a national language in independent Africa is aimed at casting away the colonial master's language and regaining lost identity by nationalizing an indigenous language. It is at this stage that a transtribal language is sought, but when there is no such trans-tribal language the foreign language is almost inevitably retained.

9.1 Some Comparative Facts. The Africans in South Africa have generally rejected Afrikaans. Afrikaans could potentially be a trans-tribal language in South Africa, like Swahili in East Africa. But the case for Afrikaans shows that even a potential language can lose its potentiality if it is tainted with certain traits.

Let us take a look at Swahili in connection with the above observation. Swahili in Tanzania has always enjoyed a popular position among the masses. The German rule encouraged Swahili. Swahili was widely spoken in Tanzania even before independence. But what was the position of Swahili in so far as matters concerning the education, and economic world of Tanzanians was concerned? There was no connection. Swahili, in other words, was used by colonial powers tc keep the people ignorant about themselves and their surroundings. The non-elite in English believed that they did not have anything to offer to their country's development, neither did they know what criteria were used for running their own country. Yet at the same time, Swahili thrived and spread among the Tanzanians. It is in such a case that we can draw an example of an elite-in a foreign language, who could see the colonizer's calculated aims and use the colonizer's language as a tool to fight against the system. A system that regarded Swahili as generally inferior.

At one stage in Kenya's history, Swahili was rejected by Africans. The major issue here was that, Swahili was used as a master-servant language of communication. Tribal languages were used in the early part of education, and Swahili was used in the later part of education. There was no proper educational material in Swahili. Neither was Swahili used as a language of the government's administration or economic world. This was a clear indication that education in Swahili would continue to keep the African ignorant about himself and the world around him.

After independence, Tanzania is a living example of how the leadership, an English-speaking elite, has raised the status of Swahili among Tanzanians. Kenya, too, has taken to the same step of re-establishing Swahili, even though at a slower pace. The question of a national language in these two African states is an important issue, because the people themselves have a choice to make without being allocated a language. 
9.2 South Africa. The Africans in South Africa view Afrikaans as the oppressors' calculated means to keep them ignorant of everything except what the present ruling regime can offer them. As seen from the facts in this paper, the present regime offers them poverty, ignorance and other ways of oppression. We noticed that English is dominant in higher education, economic fields, and the mass media. From these, we can infer that English is dominant in the politicai field. For the Africans in South Africa to fight this system of oppression and segregation, they need more than a South African 'trans-tribal' language. They need a language of much wider communication, in this case, English.

\section{Future of South Africa}

Assuming that in the future, South Africa becomes a truly independent plural society, and that South Africa follows the steps of other African countries, whereby the question of a national language becomes a burning issue, which language will be the most likely choice? It is unlikely that Afrikaans will be the choice, for history cannot be forgotten so easily. Swahili in East Africa is a language that the masses can claim allegiance to, though the colonial system was using it to ridicule the masses. In South Africa, Afrikaans is the language of the oppressor--and it has never been a language that could be isolated from the regime of oppression.

It is also unlikely that any of the African languages in South Africa will succeed as a national language. Most of them are small, and with the system of homelands, the spread of these languages has been greatly limited. People who move to other places learn other languages, rather than spreading one language, as evidence on this has been shown by looking at language in homeland schools, formation of contact languages and languages in the mines.

English, though a mother tongue of only a small percentage, seems to be the most neutral choice. Our guess is that English will be the national language of South Africa, despite all odds. It might be the case that even after English succeeds, it will still be the language of the elite. Those that won't have official education will remain ignorant in English, as is known about countries that have been faced with a similar choice, Nigeria for example.

\section{REFERENCES}

Barnouw, Adrian. 1934. Language and Race Problems in South Africa. The Hague: Mouton.

Cole, D. T. 1953. "Fanagalo and the Bantu languages in South Africa." African Studies 12.1:1-9.

Doke, Clement, M. 1939. "European and Bantu languages in South Africa." Africa 12:308-319. 
Duncan, P. 1954. "Origin of Fanagalo." African Studies 13:1-45.

Fishman, Joshua. 1972. Advances in the Sociology of Language Vol. 2. The Hague: Mouton.

Fishman, Joshua, Charles Ferguson and Jyotirindra Das Gupta. 1968. Language in Developing Nations. New York and London: John Wiley and Sons.

Kahn, E. J. 1968. The Separated People. New York: W. W. Norton and Co.

Kinloch, G. C. 1972. The Sociological Study of Johannesburg. South Africa: Macmillan.

Lanham, L. W. 1965. "Teaching English to Africans: A Crisis in Education." Optima Johannesburg 15.

Lies, Amelia. 1965. Apartheid and United Nations Collective Measures. New York: Carnegie Endowment for International Peace.

Mazrui, Ali. 1966. "The English language and political consciousness in British Colonial Africa." Journal of Modern African Studies $4: 295-311$.

Nyerere, Julius. 1968. Ujamaa. Dar-es-Salaam: Oxford University Press.

Rubin, Joan, and Björn Jernudd. 1971. Can Languages Be Planned? Honolulu: University Press of Hawaii.

Sebeok, Thomas (ed.), 1971. Current Trends in Linguistics, Vol. 7. The Hague: Mouton.

South African Government. 1974. State of South Africa (yearbook). Johannesburg: De Gemer Publishers

UNESCO. 1967. Apartheid. UNESCO.

Vatcher, William. 1965. White Laager. New York: Frederich Praeger.

Whitely, Wilfred. 1969. Swahili, The Rise of a National Language. London: Methuen \& Co. Ltd.

Whitely, Wilfred. 1974. Language in Kenya. Nairobi: Oxford University Press. 

Studies in African Linguistics

Volume 9, Number 2, July 1978

\author{
THE RELIGIOUS FACTOR IN LANGUAGE NATIONALISM \\ --THE CASE OF KISWAHILI IN KENYA
}

\author{
Al-Amin M. Mazrui \\ Stanford University
}

\title{
1. Introduction
}

Theoretical discussions on language nationalism in Kenya have so far focused on examining the national-language potentiality of one or the other of the African languages, the English language and the Swahili language 1 along the lines of two basic criteria--namely, ethnic neutrality and (socioeconomic) class neutrality. In very simplistic terms, when these languages are viewed along the lines of ethnic neutrality, the African languages seem inadequate due to their ethnic/cultural boundedness; and when viewed along the lines of class neutrality, the English language appears inadequate due to its association with the elite. So all in all, Kiswahili (Swahili language), with the popular misconception that it is a language belonging to no autonomous definable unit, emerges as the most neutral in these respects, and it is partly these factors that led to its declaration as the national language of Kenya on July 4, 1974.

Depending on specific socio-political settings, however, the religious factor can be equally sensitive in the national language question, as evidenced by the Hindi/Urdu case, for example; and this factor has not been given much attention in Kenya except in an historic sense. It is this apsect, then, that this paper aims at investigating, with the question: how does each of the languages mentioned above fare when weighed against a religious neutrality scale? The religious factor is not, of course, independent of the socio-economic relations that have existed in contemporary Kenya, but neither is the ethnic/regional aspect. For all practical purposes, linguistic "ethnicism" and linguistic "religiosism" are significant only to the extent that they are expressions of the material conditions and relations within the Kenyan society. Hence, the religious factor in this paper will be treated strictly with this consideration in mind.

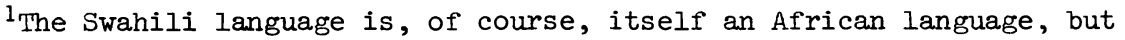
due to its status as a lingua franca it has different implications. The distinction between African languages and the Swahili language has, therefore, been made with only this consideration in mind.
} 
Bearing this in mind, then, it will be proposed here that each of the afore-mentioned languages is religious in its own sense. The scope of possible ways in which a language can be considered religious is obviously too wide for the purpose of this discussion, and we need only identify two of these--namely, extrinsic religiosity and intrinsic religiosity of a language.

\subsection{Extrinsic religiosity. This level of linguistic religiosity may} derive from:

i. the relative religiosity of a people and the culture which that language reflects and expresses. So, to the extent that an individual regards members of a particular community as being dominated by religious mores and values, he is also likely to perceive its linguistic medium as religious and react to it as a consequence of that religiosity.

ii. the relative confinement of a language to members of one religious group. If all, or a large majority of, the members of a society $S$ are affiliates of a religion $R$, then the language $L$ of $S$ may be psychologically associated with $\mathrm{R}$; $\mathrm{L}$, then, becomes religious in this instance.

Both these senses of extrinsic religiosity are, by and large, perceptions of the outergroup, that is, views that outsiders may hold towards a language used by members of, seemingly, one cultural or religious group. Under certain conditions, however, and especially under conditions of group conflict with outer groups, members of one society may also come to be conscious of the extrinsic religiosity attributed to their own language.

\subsection{Intrinsic religiosity. Intrinsic religiosity can be either overt or covert.}

i. Overt intrinsic religiosity is predicated upon the linguistic substance contained in the language. This level is, again, a possible perception of both the outer and the inner group. But, while overt intrinsic religiosity, if perceived by the inner group, normally remains at a subconscious level, it emerges to a more conscious one under certain conditions --again, especially under conditions of conflict with outer groups.

ii. Covert intrinsic religiosity stems from the association of the language as one symbolic whole with divinity. By implication, the overt and covert levels of intrinsic religiosity are, of course, inter-related, but there is a sense in which they can be thought of as autonomous levels to some extent. Consider the case of Arabic, for instance. Its overt intrinsic religiosity is clearly confined to what is called classical Arabic, in terms of linguistic substance, in contrast to other varieties of the language. At the covert level, however, it is the language whole, not characterized by any specific sub-set of linguistic material, that is significant. This distinction will become clearer as we proceed. For now let us note that unlike the previously mentioned cases, covert intrinsic religiosity is almost solely a feeling or a perception of the inner group. 
Crucial to the framework proposed above, however, is that it does not claim a generic relationship between any particular language and spirituality or divinity. Rather, this is strictly a statement of a state of mind, of the attitudes that people may have towards certain languages in relation to certain religions, universal or local, as a product of their collective beliefs and/or experiences.

Granted, then, that each of the afore-mentioned languages is or has been religious in one or more of the defined senses above, we can regard their beginning as essentially non-neutral in the religious sense. But within the course of its history the religiosity of a particular language may come to be replaced by a non-religious symbolism; and, in general, it may be that--given some more explicit definition and taxonomy of religious languages--the ease with which a religious symbolism gives way to another kind of symbolism will depend on, among other factors, the kind of religiosity which is psychologically attributed to the language. Whatever the case, one of our tasks here is to explore this phenomenon--the replacement of a religious symbolism by a socio-economic symbolism--in the context of African languages, the English language, and the Swahili language.

Approaching the situation from this perspective the argument will be advanced that the religiosity of Kiswahili seems relatively more resistant to dominance by a purely socio-economic symbolism than is the case with the African languages and the English language and that the impact of Islam and Arabic, as a religious language, has been crucial in the resistance of Kiswahili in losing its religious symbolism.

From this point on the issue that will have to be addressed is, why did this religiosity (or religious non-neutrality) of Kiswahili not contribute to its reduced success at the national level, as would have ethnic non-neutrality, for example? This, I believe, can be explained in terms of a "split" that has taken place within Kiswahili, whose reality has to be seen in the light of psychological categorization--whose emergence can be traced to the historical background of standard Kiswahili--rather than linguistic differentiation, such that we seem to have a version which is associated with the predominantly Muslim coastal community of Waswahili and another version which is associated with non-Waswahili. Suffice it to say here that standard Kiswahili, as it exists today, will fall under the category of non-Waswahili Kiswahili. So, to the extent that standard Kiswahili, a non-Muslim version, if you will, is promoted as the national norm, this split implies a kind of situation in which non-Swahili/nonMuslim Kenyans may find the "national language Kiswahili", that is, standard Kiswahili as the national norm, as religiously neutral, while the Muslim Waswahili may find it religiously non-neutral.

At this juncture we can turn to a more detailed discussion of religiosity as it relates to the linguistic. cases mentioned above and to the implications that seem to emanate from this. 
Since our main focus is on Kiswahili, and owing to space limitations, suffice it to say here that both the African languages and the English language (in the African context) can be shown to have been religious in both senses of extrinsic religiosity. From a historical perspective it can then be argued that the religiosity of these languages is dictated by material conditions and relations and, ultimately, capitulates to a socio-economic symbolism. This, then, renders the African languages and the English language religiously neutral in the long run.

\section{Religiosity and the Swahili Language}

Kiswahili could, less so now than some years ago, be regarded as both extrinsically and intrinsically religious. The extrinsic religiosity of Kiswahili derives from its being a native language to members of a predominantly Muslim community, the Swahili community. So, Kiswahili becomes religious, in this case, by its association to Islam, and to many Kenyans, in fact, the spread of Kiswahili is considered tantamount to the spread of Islam and vice versa.

Yet, despite this extrinsic religiosity of Kiswahili the language has been able to transcend its original borders at an amazing rate. What could account for this fact? Could it be correlated with the spread of Islam in East Africa? In Tanzania, where Kiswahili is very wide-spread, we also observe that Islam is widespread. But I think it would be wrong to conclude from this that the expansion of Kiswahili in Tanzania is explainable only in terms of the spread of Islam. The history of Kiswahili in Tanzania certainly entailed crucial factors other than just the religious one. One important aspect was that Tanzania initially fell under German rule, whose administration actively promoted the use of Kiswahili at all the lower administrative levels of its colony. Second, due to the predominantly trade/ economic relations between the coastal Swahili/Muslim society and the nonSwahili/non-Muslim societies of the African hinterland prior to and during German rule, the extrinsic religiosity of Kiswahili came to be dominated by its socio-economic significance, rendering it less objectionable to acquisition by non-Muslims and eventually, therefore, to its becoming a lingua franca.

In Kenya, however, the situation was radically different. In the first place there was not a colonial administration comparable to that of the Germans in Tanzania with respect to favouring the spread of Kiswahili. Moreover, the socio-economic relations between Waswahili and non-Waswahili in inland Kenya were so minimal (geographically and ethnically) because of various impediments, that the religious aspect of Kiswahili remained quite pronounced. Hence, its substantial spread was limited to those Africans who had adopted Islam, and most ot'ten, these were Africans who were themselves coastalists living in close proximity to the Waswahili.

The factor that contributed to a rapid change, in the Kenya situation leading to the spread of Kiswahili, was the birth of standard Kiswahili. 
But in what sense did the birth of standard Kiswahili make a difference? First, we know that Christian missionaries played a prominent, indeed, a central role in the standardization of Kiswahili. Second, it was the Christian missionary who became the main exponent of standard Swahili in the schools, whose initial function was to develop in the African the reading skill for Biblical studies. Third, in Kiswahili translations of the Bible and in other Christian writings, it was standard Kiswahili that was often utilized. And finally, it was standard Kiswahili or its "offshoots" that came to be used in those churches whose services were conducted in Kiswahili.

All these factors, then, if they did not cause the Christianized African to regard standard Kiswahili as the language of African Christianity, at least caused him to regard it as a non-Muslim brand of Kiswahili, as a religiously neutral brand. And any form of Kiswahili that came into being during or after the birth of standard Kiswahili was merely regarded as a "rustic" off-shoot of standard Kiswahili, an off-shoot of non-Muslim Kiswahili. Here, then we see the emergence of a cleavage within Kiswahili along religious lines, along Muslim/non-Muslim lines.

But even if standard Kiswahili in Kenya did not initiate the neutralizaton of the extrinsic religiosity of Kiswahili, the later promotion of Kiswahili at the administrative level, and its subsequent importance in geographical mobility, a factor that is directly tied to socio-economic conditions, would have obscured its extrinsic religiosity. So, whatever the case, the extrinsic religiosity of Kiswahili would, eventually, have been neutralized.

More precarious in this respect is the intrinsic religiosity of Kiswahili. This religiosity, which is basically overt, is historically a product of its lexical and phonological influences from a language, Arabic, which is itself considered religious. In other words, the intrinsic religiosity of Kiswahili emanates from its internal expression of Arabic as a religious language. But before we can elaborate on this it may be worthwhile here to consider, for a moment, the religiosity of the Arabic language.

Like Kiswahili, the Arabic language can be considered religious in both senses of the word, that is, extrinsically and intrinsically. The extrinsic religiosity of Arabic is due to its significant confinement to members of one religion. It is, certainly, not true that all who use Arabic in their daily interaction are Muslims, but it is still a substantial claim that the preponderant number of those who use it are Muslims.

The intrinsic religiosity of Arabic, on the other hand, unlike that of Kiswahili, is covert in nature and stems from the Muslims' belief that Arabic is the language of divine (Koranic) revelation. This covert intrinsic religiosity of Arabic also gave rise to ideas of overt religiosity, to regarding the linguistic substance, particularly that of the Arabic of the Koran, as divine and religious in itself. Hence, in this sense, the intrinsic 
religiosity of Arabic became compounded, and its significance to the Muslims accentuated.

In Kenya, specifically, the assertion of the religiosity of Arabic came to be most highly pronounced with the establishment of schools where English was both a subject and a medium of instruction. For example, Sheikh Al-Amin bin Ali became particularly outspoken in championing the cause of Arabic and condemned the colonial government for "suppressing" the teaching of Arabic in government schools. Actually, the teaching of Arabic never was an extensive endeavour among the Muslims themselves. Yet, interestingly enough, here was a Muslim leader condemning an auministration that would not undertake or support that same project which was only marginally undertaken in the Muslim communities. The point here is that, even though Sheikh Al-Amin was quite radical, for his time, to even encourage the learning of English to the Muslims, he could not emotionally dissociate himself from this community which equated English with Christianity and Christian civilization. His position was, understandably, that of ambivalence. And to him the only way that the colonial administration--that administration which promoted English, a Christian language, in the schools --could reduce its burden of guilt, was to institute the teaching of Arabic.

As long as the extrinsic religiosity of English prevailed, therefore, it can be said that the Muslim's demands for the teaching of Arabic also persisted. But, once the socio-economic symbolism of English came to dominate its religious symbolism, this insistence on Arabic receded. This is not to say that, at this point, Arabic ceased to be religious. Certainly not; the religiosity of Arabic just became less articulated. Material conditions changed, the socio-economic relations and statuses altered, but to that Muslim community, as to others, the Arabic language remained religious.

Let us now return to Kiswahili. With this ardent attachment to Arabic as a consequence of its religiosity, it was almost natural that the material influence of Arabic on Kiswahili be interpreted as religious influence. This intrinsic religiosity that Kiswahili came to acquire was, in fact, an object of great suspicion and rejection in certain Christian missionary circles. They opposed the very use of Kiswahili in missionary activities claiming that Kiswahili carried the spirit of Islam and could not, as such, be used in the christianization of the African. Kiswahili and Christianity were, to them, mutually exclusive entities. This notion sprouted, in part, from the predominantly Islamic background of the Swahili community, but also, importantly, from the existence of many terms of Arabic origin in Kiswahili which were regarded as being, directly or indirectly, related to Islamic institutions. To both the missionaries and the Swahili people, therefore, any attempt to "de-Arabize" Kiswahili implied its "de-Islamization", the elimination of its intrinsic religiosity.

At this point one may ask: il this material influence of Arabic on Kiswahili was considered religious, why did it not result in the rejection 
of Kiswahili by non-Muslim Africans? I think the answer to this is simply that the African was unaware of this level of religiosity. Awareness of the overt intrinsic religiosity of Kiswahili depended, of course, on two factors--namely, the association of Arabic with religion and awareness of the material influences of Arabic in Kiswahili. But since this latter factor requires some knowledge of both languages and probably some linguistic sophistication, and since this was certainly not the case with the non-Muslim Kenyan, Kiswahili's intrinsic religiosity was non-existent as far as he was concerned.

But the point may be presented that even the Mswahili did not have the linguistic sophistication to enable him to know of the existence of words of Arabic origin in Kiswahili, and without this, the Miswahili could not possibly react against the "de-Arabization" of Kiswahili. This claim is partly true; the common Mswahili is often unable to identify words of Arabic origin in Kiswahili. But the common Mswahili is also exposed to sufficient doses of Arabic during his lifetime to be able to associate at least a few Kiswahili words to Arabic origin.

More important, however, is that the Mswahili's association of Kiswahili to Arabic influence is based less on the lexical level than it is on the phonological level. Through educational socialization in Islamic madrassas and in the society at large the linguistic expression of Arabism in Kiswahili became an element of sophistication which came to be partly measured by one's ability to articulate any known Arabic borrowing as articulated in Arabic speech. So, in his reaction to Standard Kiswahili, Sheikh Al-Amin bin Ali [1932] had this to say:

It is indeed a great loss on our part to speak this Kiswahili that has been tampered with by Europeans. Kiswahili is the language of the coastal people, and it is not pure save by (retaining) its mixture with Arabic.

It is, of course, paradoxical that linguistic purity should be seen in terms of linguistic mixture, that the purity of Kiswahili should be seen in terms of its mixture with Arabic. But Sheikh Al-Amin was reacting primarily to the extracting of what is considered prestigious in Kiswahili, the implication being not only that Arabic is Kiswahili's "purifying" force, but also that to extract what has been absorbed into a language by a natural process, and especially if it becomes a mark of prestige, is as much a linguistic "impurity" as the introduction of new and foreign material. And so, in citing examples of the linguistic "pollution" that has been introduced into Kiswahili by Europeans, Sheikh Al-Amin [1932] indicates that there are: 
many Arabic words in Kiswahili... and part of the sophistication in using these words derives from pronouncing them as the Arabs do; the Europeans have changed these words by pronouncing them crudely in a way that is not considered sophisticated speech in Kiswahili such as khabari being written and pronounced as habari, khamsini becoming hamsini, -ghali becoming gali, harufu becoming herufi, ilmu becoming elimu, kuhisabu becoming kuhesabu, not to mention other words that cannot be represented by the European Ietters.

From the above quotation we may conclude that the issue is not so much "delexification", but rather, the deletion of certain sounds from the phonological system of Kiswahili as a phenomenon in its de-Arabization. And, to the common Mswahili, it is this phonological aspect as a linguistic value, more than anything else, that accounts for the split within Kiswahili.

Beiore concluding it is important to note here that within the inner group, that is, within the Swahili society itself, the linguistic Arabisms are purely a mark of sophistication, and an Mswahili who does not articulate these Arabisms is merely considered unsophisticated in his speech. Now, if for the moment we can ideologically agree that norms of sophisticated behavior are socio-economically determined, it can be said that in the context of the inner group the Arabisms in Kiswahili are more socio-economically than religiously significant. This becomes understandable if we consider that by the very nature of Arab-Swahili contact, the Arab has existed as socio-economically superior in the mind of the Mswahili.

When we are dealing with a supra-local situation, however, a situation in which the Swahili community finds itself in confrontation with other ethnic groups, then the use or non-use of these linguistic Arabisms also comes to acquire a religious interpretation. And this is precisely because, within the inner group, a person who does not articulate the Arabisms as he should is simply considered as not having succeeded in acquiring the norm of speech which he, like every Mswahili, values, while similar orientation in the outer group is seen as a conscious or sub-conscious case of deviance from the norm that has been defined by a Muslim community.

\section{Conclusion}

What has emerged from the above analysis is that precisely because African languages and the English language more readily capitulate to a socio-economic symbolism they are religiously neutralizable with greater ease than Kiswahili. In view of this impediment to religious neutralization, Kiswahili took the course to psycho-linguistic differentiation when called upon to assume the national role. As a result, however, we seem to have ended up with two categories of Kiswahili speech each of which is, seemingly, religiously non-neutral to the outer group--the Kiswahili of Waswahili is not neutral to non-Waswahili/non-Muslims, while standard Kiswahili is not neutral to Waswahili. And the selection of standard 
Kiswahili as the material base for the national norm, therefore, necessarily implies a choice of a Kiswahili that is religiously non-neutral to Waswahili.

The Waswahili are, potentially, one of Kenya's greatest resources in terms of the need to promote standard Kiswahili. How, then, are we to go about neutralizing standard Kiswahili in a religious sense so thit this resource can be fully exploited?

Is is obvious that it is not politically nor practically possible to reinstate some of the Arabic elements in standard Kiswahili so as to make it more appealing to Waswahili. In other words, even though I believe that some constraints have to be imposed on the codification of standard Kiswahili the solution to this particular problem does not lie in tampering with the present form and substance of standard Kiswahili. I believe, rather, that it lies in the Waswahili converts to the idea of a standard Kiswahili.

It is obvious that the process of codification has proceeded only to the extent of formalizing a set of rules that will make possible the generation of structures that can be considered grammatical. The norms of acceptability, however, are rather ill-defined. And the absorption and active participation of these Waswahili converts in the levels of formulation-along the lines of norms of appropriateness that already exist in the Swahili community--and implementation of such norms will be a significant step towards the reduction of Waswahili's ambivalence to the standard/ national norm.

It is most likely that, with time, a wider variation in speech within Kiswahili will emerge, and, as a result, appropriateness will take on a different form in each of these varieties. Due to this it has been suggested (see, for example, Harries [1976]) that norms of appropriateness should be allowed to emerge as a natural phenomenon, and whatever set of norms that manages to establish itself over others would be integrated into the standard norm. But in my opinion, this argument misses an important point. In fact, a similar argument could have been presented with regard to the choice of a base dialect for standard Kiswahili. What is important here is that a specific region which has been faced with specific language problems has resorted to language planning to solve these problems under the given conditions. If natural phenomena are allowed to take precedence then we have no use for language planning.

\section{REFERENCES}

Al-Amin b. Ali. 1932. Al-Islah. July 1932, pp. 1-2.

Harries, L. 1976. "The nationalization of Kiswahili in Kenya." Language in Society 5: 23 . 



\title{
LANGUAGE PLANNING AND ONOMASTICS IN ZAIRE ${ }^{1}$
}

\author{
Tshimpaka Yanga \\ University of Texas at Austin
}

\section{Introduction}

Various studies in the last few years have focused on different aspects of language use and language change for the purpose of nation building. Scholars have been dealing with "deliberate language change" performed either on the code, speaking patterns or both, within a particular speech community [Rubin and Jernudd 1971:xvi]. In this paper there is a discussion of changes in both code and speaking patterns as related to the onomastic system in the Republic of Zaire. The goal of this discussion is to point out and explain the relevance of onomastic systems to language planning for the benefit of ethnographic studies. The view taken here is that, since the onomastic systems reflect conventionalized practices in given societies, they must be planned in such a way that they will preserve and maintain their cultural identity.

\section{Background}

The problem of proper names for persons and places has been one of the crucial issues in the national affairs of Zaire, but has received very little space in the literature which focuses on the sociolinguistic problems of the country. Most writers concentrating on these language problems have mainly paid attention to general aspects of the sociology of language, such as the possibility of a "national language", standardization, language problems as reflected in the education system, and communications in the broad sense of circulation of information, etc. (see [Alexandre 1967; Mateene 1964, 1967; Polomé 1963, 1968]). As an example, it was in 1974 that the first National Seminar of Linguists

lThis is a slightly revised version of the paper which I presented at the 8th Conference on African Linguistics. I would like to acknowledge Profs. Ben Blount, Brian Stross, Hazel Carter and Joel Sherzer for their constructive comments. Due to space limitations and the scope of this paper, it wasn't possible to make revisions in accord with all of the suggestions given. These comments and suggestions, however, will be incorporated in an expanded version of this paper. Many thanks to my friend Sukari Saloné for her assistance in preparing the final text for publication. 
of Zaire was held at the National University of Zaire (Lubumbashi campus) to examine:

a. The promotion of the national languages in the framework of Zairian nationalism of resorting to authenticity;

$\mathrm{b}$. the teaching of languages in Zaire (teaching of Zairian languages, teaching in Zairian languages and teaching of foreign languages in Zaire);

c. research on Zairian languages and perspectives for the future;

d. standardization of the orthography of the Zairian languages;

e. creation of the national Society of Linguists of Zaire.

As mentioned above, this was the first time that concerted efforts were made to analyze in a preliminary framework the current sociolinguistic situation in the country. However, no particular attention was paid to the area which constitutes the topic of the present study.

A brief look at the literature on onomastic systems in the world reveals that this domain has always been of concern, and for various purposes. R. Ferguson was concerned about the etymology of family names in France, England and Germany as they were related to the Teutonic name-system. He pointed out that:

The etymology of proper names is the only branch then of the subject which can in any sense be called popular; for what men, even of those who care not to enquire the origin of the language they speak, feel some interest or curiosity in knowing the meaning of the names they bear. [1864:3]

A. Dauzat illustrated the psychological, social and linguistic relevance of proper names in addition to the classificatory distinction between individual and collective names [1925:6-13]. The geographical nomenclature of the Kwakiutl Indians of British Columbia, as analyzed by F. Boas [1964:171-176], furnishes a good example of the ethnographic value of proper names. His effort showed that those geographical names were a reflection of both cultural patterns and linguistic potential.

The importance of names in the maintenance of social structure has been reported by Radcliffe-Brown about the Chinese method of giving names to offspring. With this method, everyone has three names:

The first is the lineage or family name; the second indicates the generation to which he belongs; the third is his distinctive personal name. From the second part of the name any member of the lineage can tell to which generation any particular individual belongs." [1950:14]

Thus, their system not only helps them to maintain the distinction between generations, which is an important feature of social structure, as explained by the author, but also has some implications for the rules 
of marriage ${ }^{2}$. Therefore, it appears evident that such a systeir of naming is a strlictured process having ius own social value among other institutionalized behaviors in this particular comrunity.

In his description of the nodes $0:$ livelihood of the Nuer people in East Africa, Evans-Fritchard [1940] has shown the social va] ue of cattle as it is directly nanifested in the onomastic and greeting systems. This should not be surprising for those familiar with the role played by cattle among the Nuer. Indeed tine latter, as explained by Evans-ritchard, take some of their names iron the cattle terminology (ox-names) and it is the latter which are favored in sailitations. Both attle nanies and ox-names of people are used in song and poetry [1940:45-49]. In another paper, "Nuer modes of address", [1964:221] he clearly aescribed tine importance of names and titles of address among the Nuer by pointing out; that "they symbolize a man's social position in relation to the people around hin, so that, by the use of one or other of them, the status of the speaker to the person adiaressed is readily recognized."

The importance of numes in this particular society was not only limited to the cattle terminclogy and their interaction with social events, but names also appeared to play a kej role in the l.uer conception of time and space and in reference to their age-set system. The names given to years, for instance, reflected some crucial events that have marked the life of the group (floods, pestilences, famines, wars, etc.) [1940:105]. Evans-Fritchard's effort was to draw attention to this onomastic system and show that "a study of the dominant interest of the Nuer might be approached from this angle." [1940:48]

G. Nissim [1973] has approached a nuniter of African societies in Chal, Togo, Cameroon, Mali, and Upper Volta trying to show how traditional nanles reflect the sliritual relationships between God ano people. A. B. Weiner [1976] has described the naming process which denotes an aspect of the Trobriand cultural identity.

With regard to Zaire, one might refer to a brief analysis made by E. Folome [1958] in which he skows the ethnographic meanings of some selected personal names amone the Bakongo of Lower Zaire, Batetela-Bakusu of Sankuru and Maniema, and Baluba of Kasayi and Northern Shaba. FaikNzuji [1974] has also attempted to look at the origin, naning processes,

${ }^{2}$ Radcliffe-Brown explains that the Chinese rule of exogamy prevents persons with the same surname from marrying each other: "Since such names are partilineally inherited and therefore the two persons of one name may be supposed to have had an ancestor in common, though it may be three thousand years aco" [1950:67]. Also in his On Joking Relationships [1.940], reprinted in Radcliffe-Brown [1952:102], he has shown the importance of names in the maintenance of the socia? structure. 
grammatical and semantic structures of some selected personal names among the Baluba of the Kasayi region.

In all of the studies mentioned above, there is an obvious recognition of the relevance of onomastic systems to the sociolinguistic situations in various parts of the world. However, there has not been any direct relationship that I am aware of between the current theories and practices in language planning and onomastic systems of any particular population. To ignore this domain of the culture is to miss an important aspect of the ethnography of its speech community. Thus, an effort is made in the present analysis to show that proper names play a key role in a speech community as "linguistic indicators" of socialization. In this approach some aspects of the planning as they were implemented and cultivated in Zaire will be presented, namely the problem of the name of the country itself, the problem of "Western first names", names of foreign peoples which were given to towns, streets and historical sites, and finally changes made in the greetings, terms of address and names of administrative divisions will be examined.

\section{Name of the Country}

Before 1885, the "Congo Basin"3 was not a unified country as it is at present. At that time, there were various kingdoms and states which occupied this huge territory. In May, 1885, the Berlin Conference determined the partition of the continent between the existing powers, and Congo Free State was founded. The new entity included then all of the independent and autonomous kingdoms and states. The name Congo was actually the name of the kingdom of the BaKongo group. The choice of the name Congo for the whole territory might have been a result of the close contacts which this group had established with Westerners long before they went into the interior of the country. For instance, E. Polomé [1968:297] has mentioned that "Kikongo" was the first Bantu language known to Europeans. Obviously, the name "Congo Free State" was a reflection of the socio-political situation between the country and the western powers at the time. Under this name cccurred one of the worst forms of colonization ever recorded in the world (see Leo Frobenius [1907] in B. Davidson [1964:364-365]).

A few years later, development in the European political and economic arena, and especially the need for permanent exploitation of the country, brought changes in the Belgium--Congo Free State relationship. Thus, on September 9, 1908, after twenty-three years of existence, the Congo Free State was annexed to Belgium as a colony [Bustin 1963:29]. This change was manifested in the name of the country: Congo Free State became Belgian Congo. It is this name which was associated with the

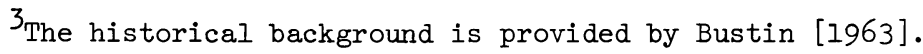


country for half of this century, and which identified the country with the colonialists. The independence of the country on June 30, 1960, from Belgian rule, naturally affected the name of the country again. The latter was renamed The Republic of the Congo (Léopoldville). Notice that it was necessary to specify Léopoldville since there was another Republic of the Congo (Brazzaville) across the river. In fact, this confusion was partly a result of the arbitrary establishment of the present political boundaries in the continent. However, since 1960 there have been variations and changes in the naming of the country. The Republic of the Congo (Léopoldville) did not last long. Thus, after a painful period immediately following Independence Day, the name of the country was changed from the Republic of the Congo (Léopoldville) to Democratic Republic of the Congo (Léopoldville). Here the change was mainly the addition of "democratic". Shortly after, Léopoldville was substituted by Kinshasa. The substitution of Kinshasa for Léopoldville characterizes the first attempt by the government to recover the authentic name of the region. The name Léopoldville remained in historical records. However, recently (1971) there has been a radical change in the name of the country. The Democratic Republic of the Congo (Kinshasa) was changed into the Republic of Zaire. One realizes how much information is contained in the different names of this country. These names reflect and constitute an index of the various socio-political events which have marked the history of the country and its people.

The change of name to the Republic of Zaire occurred on October 27 , 1971. This date, in fact, is one of the historic moments of achievement of the 'Second Republic' led by President Mobutu Sese Seko. The word Zaire is a 15th century Portuguese mispelling of the authentic Kikongo word 'Zadi'. The latter was the traditional name of the national river ${ }^{4}$, which is thought of as the symbol of Zairian unity. The change of the name in 1971 happened at a time when Zairian peoples were in search of a new spirit and revival of authentic traditions which would express the national identity. Since the former name (Congo) became synonymous with anarchy, secession, rebellion and various types of disorder, it was an effective action to change this state of mind. This change coincided with the 6th anniversary of President Mobutu Sese Seko's regime, and was part of a mental decolonization process undertaken by the government. Thus, the change of the name had strong psychological effects on the population. The mass media, especially the radio stations, reinforced the implementation and participated intensively in the cultivation of this reform. In connection with the government programs (lectures, speeches, etc.), the media helped quickly to erase the former name in the national vocabulary (except, of course, for the nostalgic people who would rather have seen the former situation be perpetuated).

\footnotetext{
${ }^{4}$ From the Shaba region to Kisangani, the river is called Lualaba, but from the Kisangani region to the Atlantic Ocean it is called Zaire.
} 


\section{Individual Names}

For those familiar with the ethnographic literature on African societies, the role of personal names in socialization is not a mystery. The individual names very often reflect the interaction of people and their environment. Social relationships and spiritual life are expressed through these names. This is by no means a peculiarity of African societies. In the works cited above, one will find the same type of correlations in other societies throughout the world. However, the objective here is to show their relevance to language planning.

The change of the name of the country was not an isolated fact. It was part of a decolonization process, led consciously by the government in accord with Zairian nationalism. Along with the country, all of the streets, cities, and country sites which were formerly given colonial names were changed. All of these places, streets or sites, recovered either their traditional names, that the Belgians had minimized or received new and authentic Zairian names. The lyrics and melody of the national hymn were also changed. These reforms in language use were launched in order to regain the national identity. It would be alienating (in the Zairian context) to maintain colonial names which through their nature remind people of those dramatic years of disruption.

Not only were the streets, cities, parks, lakes and buildings debaptized, but western "first names" such as Alexis, Jean, Pierre, André, Anne, etc. were also abolished for the Zairian people. In fact, this system which was imposed on the population by the missionaries and the colonial administrators did not fit into the traditional African ways of naming children. Unfortunately, the authentic African names were symbols of paganism for the earlier missionaries.

Faik-Nzuji [1974] has suggested for Luba personal names that: 1) their coinage is a result of a socio-cultural motivation, and not a random fact; 2) their analytic interpretation should proceed by a morpho-semantic analysis [1974:3-4]. Examples:

$$
\begin{array}{ll}
\text { Mbuuyi } & \text { 'the oldest twin' } \\
\text { Kânkú } & \text { 'the youngest' } \\
\text { Múswămba } & \text { 'the child born after twins' } \\
\text { Kábishi } & \text { 'premature child' (derived from the adjective } \\
& \text {-bishi 'raw' ) }
\end{array}
$$

However, let us note that not all of the proper names have a particular meaning in the community. For instance, she gave some personal names such as Mpóóyí, Odya and Bóóyí which apparently do not have any structural relationship to other elements of the Luba language, but which have been recognized by the speech community and transmitted as proper 
names [1974:4]. Although she did not expand her analysis, she has nevertheless indicated the functional role of those personal names.

of special interest here is the "reincarnation" process in Luba naming, which she observes is most generally used. Two aspects characterize this process: namely, the "re-birth" and the "power of the name".

The re-birth essentially consists of the belief that the newborn is one of the ancestors who has come back. Thus, his names should be given to the child, and in so doing, that ancestor (i.e. his memory) is perpetuated. In many cases this name will influence the behavior of the parents toward the child in social contexts, depending upon the structural relationship between the ancestor, whose name was given to the child, and the child's parents. Notice that the notion of "reincarnation" has also been reported by Radcliffe-Brown [1950:20] among the Henga, in connection with the process of giving the name of a grandparent to a grandchild.

The power of the name consists of the belief that the name represents the soul of the individual. Therefore, to inherit or to receive someone's name, is to inherit or receive at the same time his qualities, faults and even his destiny [Faik-Nzuji 1974:7-8]. It is not the purpose of this paper to examine these aspects of personal names in detail. However, they are relevant, and the subject of a projected systematic analysis of the correlation between names, individuals and social interactions in Zaire. The account given here is a simplified description of more complex social phenomena supporting this analysis.

Besides the reincarnation process, there are additional processes relating to the birth or conception circumstances which have important ritual functions in the community. Thus the system of "first names" referred to above was completely inappropriate. Moreover, in many cases, these first names were last names of some foreign citizens in their own culture. Therefore, the authorities decided to stop these alienating practices. In order to convince people of the decisions, the President himself gave the example by changing his identification from Joseph Désiré Mobutu to Mobutu Sese Seko Kuku Ngbendu Wa Za Banga. Reforms in individual names occupied a large space in the key issues of the country for a long period of time.

Resistance from the Church, which saw language reform as an attempt to interfere with its missions, led government officials to deliver many popular speeches which explained the rationale behind these actions. The government showed that changes made in the onomastic system should not be taken as actions against religion, since faith cannot be identified with a particular type of name. The population was then required to take only the authentic country names inherited from the ancestors.

Misleading interpretations and commentaries in Europe made it neces- 
sary again for the government to extend its explanation to the world community. Thus, Mr. Sakombi Inongo, then "Commissaire d'Etat" at the Zairian Department of Orientation, as a direct representative of the President, lectured in Dakar, Brussels, and Paris. This was part of the government's program to explain the essence of "Zairian authenticity" in general and the rationale behind the changes made in the onomastic system. He used the example of the name of the President himself, first to give its correct meaning, and secondly to show that the authentic names have an ethnographic value for the people. The text below is illustrative ${ }^{5}$ :

Thus, there was in Zaire what has been callea the first names affair and what has been the occasion, in Europe, of commentaries either unfavorable or humoristic. Some newspapers succeeded in giving fanciful translation of the authentic names of General Mobutu. Although flattering for the virile character of our Chief of State, these translations were, no less, false. Mobutu Sese Seko Kuku Ngbendu Wa Za Banga. Each name has an ancestral reference. Mobutu Sese means the inveterate defender of the forefathers' land. Mobutu Seko, the audacious warrior who ignores the defeat because his endurance wins. Mobutu Kuku Ngbendu, or Mobutu Wa Za Banga means the powerful warrior going from conquest to conquest without being stopped. There is a Gallic proverb which says "We do not have part to the glory of our forefathers unless we force ourselves to resemble them." You would not like, Gentlemen, to deny for General Mobutu the qualities of courage and force whıch, according to your own ancestors, he has inherited from his forefathers."

This text is a fragment of the lecture given by Mr. Sakombi Inongo in Paris on April 3, 1973 for the French public. It appears to fit well with the notion of reincarnation discussed above.

As one can imagine, the problem of changing names was a serious one at different levels of the community. Tremendous efforts were made to implement and cultivate these changes. Thus, the reforms took place in macro and micro contexts affecting both French (foreign language) and the "four national languages". At the macro level, the vocabulary was marked by the term "Zaire", which identifies three realities, namely: the country, the currency and the river. Administrative divisions left

${ }^{5}$ The original text may be found in Sakombi Inongo [1973]. In the translation given here, an effort has been made to remain as close as possible to the original version. Some other data on the problem of names in general may also be found in "Le MPR à Six Ans", May 30, 1973. Kinshasa, Department of Orientation. 
by the colonialists, such as "chefferies", "communes", "provinces" (see E. Polomé [1968:295-298]), were respectively substituted by "collectivities", "zones" and "regions". Their respective colonial names such as "Elizabethville", "Léopoldville", etc. were changed to "Lubumbashi", "Kinshasa", etc. For one's spatial orientation, these changes have an obvious importance.

\section{Greeting System}

At a micro level (in social interactions) besides the reforms in the system of first names, some terms used in the greeting system (terms of address) and correspondence were changed. Thus, French terms such as "monsieur", "madame", "mademoiselle" were respectively substituted by "citoyen/citoyenne". The term "citoyen" also replaced titles such as "Son Excellence". The feminine form "citoyenne" reduced the social distinction between madame/mademoiselle. It is interesting to notice the complexity of these language changes in a multilingual society like Zaire. Code switching and language planning would be crucial to analyze in the framework of these reforms. For instance, western first names were abolished in favor of native names in Zairian languages. But since French is still the official language in Zaire, the changes in administrative terms and the greeting system have been effected with substitution of other French lexical items. However, since everyday speech behavior is marked by various code switchings (involving all of these languages and depending upon specific contexts and status of the speakers,) it would not be surprising to find the reforms discussed above reflected in the code switchings, especially in the "political vocabulary".

It is important to point out that these changes have been introduced to affect the Zairian population. As in the case of the titles used in addresses, terms such as "monsieur" or "madame" will be employed whenever a Zairian interacts with a foreigner, but the foreigner who has been in the country and knows about the socio-linguistic rules, would be expected to use "citoyen(ne)" when replying. Among Zairians themselves only the latter form is used. All of these variations in the sociolinguistic situation have been extensively exploited by the radio stations for their implementation as already mentioned. The President himself spent months travelling throughout the various regions in an effort to implement the new language policy and at the same time to evaluate its efficacy.

\section{Discussion}

This paper has sought to point out an aspect of language use which seems neglected in the literature on language planning. Proper names and terms of address are so involved in everyday activities that people take them for granted. In Zaire, personal names do not merely distinguish people from each other; they also operate as "linguistic indicators" of socialization, in that they are usually representative of various social relationships within a family. At a more general level, they play an 
indexical role reflecting the sociocultural changes or events in the community.

It is believed that from a systematic examination of onomastic systems in countries which, like Zaire, rely upon oral traditions, further insights could be gained about social organization.

The relevance of this paper lies in its implications for a general analysis of the sociolinguistic situation in countries facing the problems of "nationality planning" [Fishman 1974:84]. Decisions made by the Zairian government concerning language use as a national resource, were politically motivated, but naturally linguistic ones. The importance of these changes in the verbal repertoire is also indirectly felt in the economy, as can be seen once one imagines that to change the name of the country, sites, buildings, streets or personal names requires consequently the change of those names in official documents, business documents, new identification cards, maps, etc.

It has been documented here that the Zairian onomastic system reflects the history, culture and the socio-political events which have marked the national scene. However, it is amazing and sometimes disappointing to realize that most of the planners have not noticed the importance and the linguistic nature of the political decisions made in this domain. Hopefully, more attention will be paid to these changes which have been successfully carried out in the permanent search for the recuperation and affirmation of the national identity.

\section{REFERENCES}

Alexandre, P. 1967. Langues et Langage en Afrique Noire. Paris: Payot.

Boas, F. 1964. "On geographical names of the Kwakiutl." In D. Hymes (ed.), Language in Culture and Society, pp. 171-181. New York: Harper \& Row.

Bustin, E. 1963. "The Congo." In G. M. Carter (ed.), Five African States: Response to Diversity, pp. 9-159. New York: Cornell University Press.

Dauzat, A. 1925. Les Noms de Personnes: Origine et Evolution. Paris: Libraire Delagrave.

Evans-Pritchard, E. 1940. The Nuer. Oxford: Oxford University Press.

Evans-Pritchard, E. 1964. "Nuer modes of address." In D. Hymes (ed.), Language Culture and Society, pp. 221-227. New York: Harper \& Row. 
Faik-Nzuji, C. 1974. "Observations préliminaires sur les anthroponymes Luba du Kasaayi." Linguistique et Science Humaines, 14. Lubumbashi: UNAZA/CELTA.

Ferguson, L. 1864. The Teutonic Name-System Applied to the Family Names of France, England \& Germany. London: Williams \& Morgate.

Fishman, J. A. 1974. "Language planning and language planning research: the state of the art." In J. A. Fishman (ed.), Advances in Language Planning, pp. 15-33. Paris: Mouton.

Frobenius, L. 1907. "Leopold's Congo." In B. Davidson (ed.), The African Past: Chronicles from Antiquity to Modern Times. New York: The Universal Library. 1964.

Jernudd, B. A. and J. Das Gupta. 1974. "Towards a theory of language planning." In J. Rubin and B. A. Jernudd (eds.), Can Language Be Planned?, pp. 103-124. Honolulu: The University Press of Hawaii.

Mateene, K. 1964. "Trois langues pour le Congo." Remarques Congolaises et Africaines, 21.

Mateene, K. 1967. "Du choix du liNgala comme langue national congolaise." Voix Muntu, 10. Kinshasa: Université Lovanium.

Nissim, G. 1974. "Les langues africaines et la pensée religieuse." Les Langues Africaines: Facteur de Développement, pp. 107-123. Douala: Collège Libermann.

Polomé, E. 1958. "Personennamen bei einigen Stamen in Belgish-Kongo." Paper presented, VIth International Congress in Onomastic-Sciences. Minchen.

Polomé, E. 1963. "Cultural languages and contact vernaculars in the Republic of the Congo." Texas Studies in Literature and Language, 4: 499-511.

Polomé, E. 1968. "The choice of official languages in the Democratic Republic of the Congo." In J. A. Fishman, C. A. Ferguson, and J. Das Gupta (eds.), Language Problems of Developing Nations, pp. 295-311. New York: John Wiley and Sons, Inc.

Radcliffe-Brown, A. R. 1940. "On Joking Relationships." In A. R. Radcliffe-Brown (ed.), Structure and Function in Primitive Society, pp. 90-104. New York: The Free Press. 1952.

Radcliffe-Brown, A. R. 1950. "Introduction." In A. R. RadcliffeBrown and D. Fortes (eds.), African Systems of Kinship and Marriage. London: Oxford University Press. 
Sakombi, I. 1973. Authenticité à Paris. Kinshasa: Départment de I' Orientation Nationale.

Weiner, A. B. 1976. Women of Value, Men of Renown: New Perspectives in Trobriand Exchange. Austin \& London: The University of Texas Press. 
Announcing a new journal for ffrican languages and linguistics:

\section{E'IUDES LINGUISTIQUES}

Etudes Linguistiques, published by the Linguistics Department of the University of Niamey, has the goal of promoting the study of languages spoken on the African continent, and more particularly in Niger (vithout excluding the possibility of publishing research on other linguistic grouns) as well as the development of linguistic theories.

The first issue will anpear around January, 1979.

The journal will accept all texts regarding current research in the domains cited. It will also include, in order to encourage exchange of ideas and research, a section "Notes and Discussion", which will present brief research notes and critical resumes of relevant works and will provide a forum for the expression of different points of view.

Several pages will be reserved for general information (bibliographies, announcements of conferences or research projects, etc.).

Secretary-general in charge of coordination will be Robert Nicolal.

Manuscripts and proposals for articles or book reviews, in French or in English, as well as general correspondence, should be addressed to:

\section{Monsieur le Secrétaire Général des "Etudes Linguistiques"} Université de Niamey

B.P. 418

Niamey, NIGER

Subscriptions can be requested from:

"Etudes Linguistiques"

Service des abonnements

Département de Linguistique

Université de Niamey

B.P. 418

Niamey, NIGER

Bank account numbers and a postal checking account will be published in the first issue, as well as author's guidelines for the presentation of manuscripts. 
